Portland State University

PDXScholar

\title{
The foundation for revolution : educational reforms in late Ch'ing China
}

Andrea Asbell

Portland State University

Follow this and additional works at: https://pdxscholar.library.pdx.edu/open_access_etds

Part of the Chinese Studies Commons, Education Commons, and the History Commons Let us know how access to this document benefits you.

Recommended Citation

Asbell, Andrea, "The foundation for revolution : educational reforms in late Ch'ing China" (1991). Dissertations and Theses. Paper 4125.

https://doi.org/10.15760/etd.6009

This Thesis is brought to you for free and open access. It has been accepted for inclusion in Dissertations and Theses by an authorized administrator of PDXScholar. Please contact us if we can make this document more accessible: pdxscholar@pdx.edu. 
AN ABSTRACT OF THE THESIS OF Andrea Asbell for the

Master of Arts in History presented July 24, 1991.

Title: The Foundation For Revolution: Educational Reforms in Late Ch'ing China

APPROVED BY THE MEMBERS OF THE THESIS COMMITTEE:

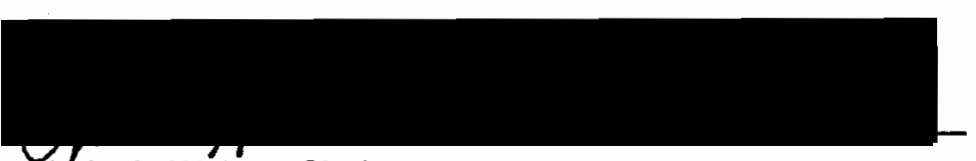

Yirrda A. Walton, Chair

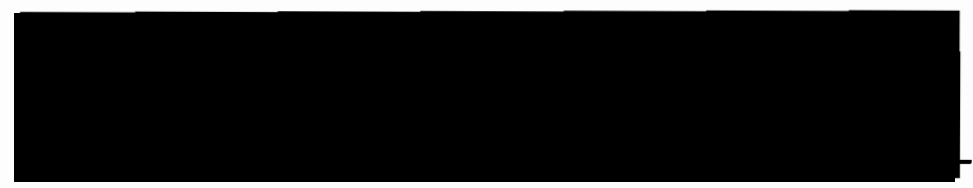

Michael F. Reardon

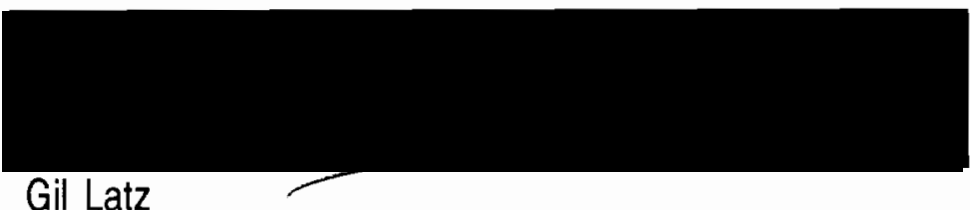

Historical consensus has labeled the educational reform efforts of China's scholar-officials in the second half of the nineteenth century as merely reactions to external circumstances and therefore has concluded that these reforms were "failures". The youthful revolt against Chinese cultural traditions, which culminated in the May Fourth Movement of 1919 , has frequently been cited as a clear demonstration that previous educational reforms had failed. However, when viewed as the intellectual phase of the revolutionary process, reform activities among members of China's bureaucratic and scholarly elite in the four and one half decades from the 1860 s to the 
early 1900 s can be seen as limited, but definite, successes, initiated from within the traditional society and assisted by the introduction of Western secular knowledge by Protestant missionaries.

There were actually two phases to educational reform. The first period, 1860 to 1890 , was dominated by individual efforts, which were loosely connected by a shared belief in the need for China to strengthen itself through the selective adaptation of Western technologies. The second began in the 1890s and was characterized by the development of a general intellectual climate for educational reform, which included not only the adoption of Western technologies but also the investigation of Western philosophies and political theories. The 1902 Imperial edicts, establishing the first truly public system of education in China, represented an official acknowledgment that a fundamental shift had already occurred in Chinese intellectual foundations. This shift represents the first, intellectual, phase of the Chinese revolution and was critical to the development of the following stages of the process - the political revolution begun in 1911, and the sociocultural transformation initiated in 1915. Political solutions proposed for the problem of China's national survival in the twentieth century and sociocultural debates over the the relevance of the Chinese tradition to a modem nation-state must be considered as indications that a fundamental shift had already occurred in the intellectual foundation by the beginning of the twentieth century. This shift represented a successful result of educational reform efforts in late Ch'ing China. 
THE FOUNDATION FOR REVOLUTION:

\section{EDUCATIONAL REFORMS IN LATE CH'ING CHINA}

\section{by}

\section{ANDREA ASBELL}

A thesis submitted in partial fulfillment of the requirements for the degree of

\section{MASTER OF ARTS \\ in \\ HISTORY}

Portland State University

1991 
TO THE OFFICE OF GRADUATE STUDIES:

The members of the Committee approve the thesis of Andrea Asbell presented July 24, 1991.

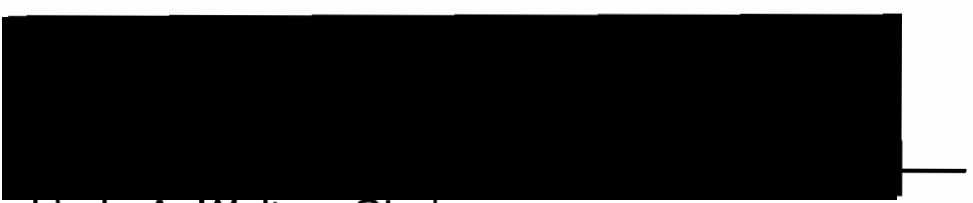

Linda A. Walton, Chair

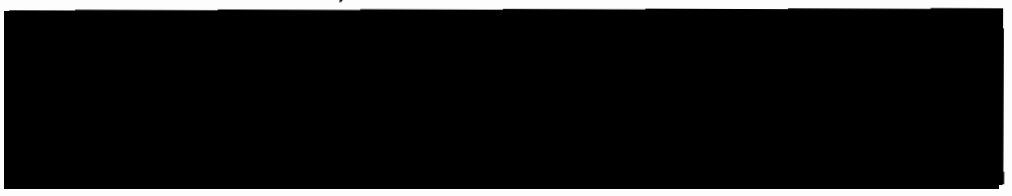

Michael F. Reardon
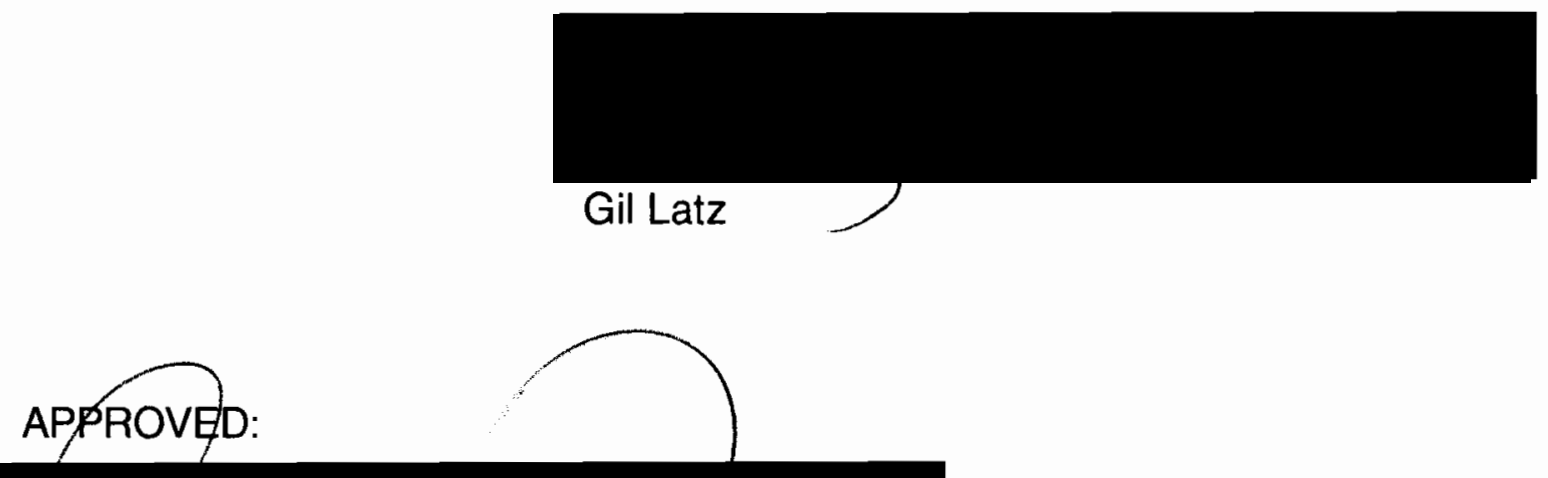

Bernard V. Burke, Chair, Department of History

C. William Savery, Vice Provost for Graduafe Studies and Research 


\section{TABLE OF CONTENTS}

I EDUCATIONAL REFORM AS A TRANSFORMATIONAL PROCESS . . . . . 1

II CHINESE SCHOLAR OFFICIALS AND THE STATE $\ldots \ldots \ldots \ldots \ldots \ldots \ldots \ldots \ldots$

Traditional Education and the Examination System: The Concept of

Public Structure and Private Instituions

Traditional Scholar-Bureaucrats As the Agents of Reform:

The Transitional Generations

The Chinese Intellectual Environment For Educational Reform:

"Internal Choas and External Troubles".

The Political Context of Reform in Late Ch'ing China:

"Self-Strengthening" in the Provinces and "Restoration" at the Court . . .

The Problems of Reform in a Traditional System:

"Official Failures" and "Unofficial Successes".

Educational Reform and The First Transitional Generation:

Individual "Succeses" and General "Failure".

III BUILDING UPON THE FOUNDATIONAL SHIFT IN THE INTELLECTUAL CLIMATE

The Structure Developed By the Self-Strengthening Efforts:

Specialized Institutions and a Traditional Base . .

Missionary Sponsored Education Activities:

Publication, Secularization, and the Search for "Common Ground" .....

Treaty Ports and the Introduction of Western Learning:

New Interactions and Nontraditional Intellectuals

Educational Reform Within Traditional Structures:

A Continuation of the Self-Strengthening Pattern 
IV THE SECOND TRANSITIONAL GENERATION AND REFORMS ........... 89

The Intellectual Climate on the Eve of the Sino-Japanese War ........... 89

New Voices in the Developing Reform Movement:

Serious Questions and Growing Concerns ........................... 96

The Spread of "Reformism" Throughout the Intellectual Ranks

A Critical "Change of Situation" in China . . . . . . . . . . . . ..... 110

A Gathering of "Men of Talent" in Hunan Province:

The Politicization of Educational Reforms . . . . . . . . . .................... 124

Educational Reform Moves To Center Stage:

The 1898 Reform Movement and the Exhoratation to Leam ............ 129

$\mathrm{V}$ THE LEGACY OF CH'ING EDUCATIONAL REFORMS.............. 141 


\section{CHAPTER I}

\section{EDUCATIONAL REFORM AS A TRANSFORMATIONAL PROCESS}

On May 4, 1919, the students from Peking's universities poured into the streets of the Chinese captial to protest the decisions regarding Chinese territories that had just been announced half a world away at the Peace Conference in Versailles, France. For contemporary China watchers and later Sinologists, this was a momentous occasion and one of those significant dates which mark a turning point in that vast country's development. The importance of this date to the Chinese people and in Chinese intellectual history is underlined by the popular description of May 4, 1919, as "The Day Confucius Died." Obviously, this day in the twentieth century did not mark the actual death of the Great Sage, himself, but marked the rejection of his intellectual legacy, which had stood in place as the foundation of Chinese education and sociopolitical thought for over two thousand years. If May 4, 1919 represented a rejection of the Confucian heritage of the Chinese people, then could it also be said to mark a rejection of all previous attempts to reform that heritage?

One possible answer to this question was a resounding yes, and that became the conclusion for some contemporary historians and social critics.' However, for a group usually associated with a rejection of traditional China and its reform efforts, the Marxist historians of the $\mathrm{PRC}^{2}$, there was a different conclusion, as shown by this evaluation of earlier reforms issued by the

\footnotetext{
${ }^{1}$ This was particularly true for Western writers in the early years of the twentieth century and in the years before and after the May Fourth Movement. Some examples of this attitude can be found in the following studies: Meribeth E. Cameron, The Reform Movement in China, 1898-1912 (New York: Octagon Books, Inc., 1963), originally published in 1931 by Stanford University; J. Martin Miller, China: Ancient and Modern (Copyrighted in 1900 by the author, no publisher listed); and Paul S. Reinsch, Intellectual and Political Currents in the Far East (Freeport, N.Y.: Books for Libraries Press, 1971) a reprint of the original 1911 publication.
}

${ }^{2}$ Acronym for People's Republic of China, the communist state proclaimed by Mao Tse-tung on October 1, 1949. 
"Compilation Group" for "The History of Modern China Series ":

"As Lenin says, 'Every reform is a reform (and not a reactionary and not a conservative measure) only insofar as it constitutes a certain step, a 'stage,' for the better. But every reform is introduced 'in order to stem, weaken, or extinguish the revolutionary struggle, in order to fragment the strength and energy of the revolutionary classes.' The Reform Movement of 1898 launched by China's bourgeois reformists, though reactionary by its very nature, was precisely such a 'step' and 'stage'."'

Therefore, for some of the harshest critics of the Chinese tradition, nineteenthcentury reforms not only could not be considered failures but should also be considered successes, because they represented official attempts to adjust the system in reaction to the larger "process" of revolution and affected the development of that revolution.

Another perspective on this question places the May Fourth Movement (Wu-ssu yün-tung ) within a broader developmental process. If the Movement is considered one in a series of revolutionary activities that occurred in the transitional century from 1850 to 1950 , then the question of a substantial break from the past becomes irrelevant. In his study of revolutionary developments in Hunan province in the early years of the twentieth century, Joseph Esherick noted that the 1911 revolution in China was actually a confirmation of the success of the previous reform processes, that "the very success of reforms bred revolutionaries." "In 1944 Republican China, one of the members of what came to be known as "The May Fourth Generation", Li Ch'ang-chih, wrote:

"The May Fourth Movement...means, of course, not merely the movement which took place on the day of May 4, 1919; it denotes a cultural process resulting from China's contact with Western civilization. The May Fourth Incident was but a signal in this process." ${ }^{5}$

${ }^{3}$ Compilation Group, The Reform Movement of 1898 (Peking: Foreign Languages Press, 1976), p. 124. The underlining is mine for emphasis.

${ }^{4}$ See Joseph W. Esherick, Reform and Revolution in China (Berkeley: University of California Press, 1976), p. 7.

${ }^{5}$ See Chow Tse-tsung. The May Fourth Movement (Cambridge: Harvard University Press, 1960), p. 4. 
This process of cultural contact affected the Chinese people and state on a variety of levels, ranging from sociopolitical interactions (military engagements to economic ventures) to intellectual responses (cultural retrenchment to educational reforms). It is within the realm of these intellectual responses that some of the most fundamental changes in Chinese culture took place. These were the changes that Esherick termed a "success" and that $\mathrm{Li}$ wrote of as the "cultural process."

The intellectual developments in this period of Chinese history were of such an overwhelming number and of such a fundamental nature that they cannot be considered from just the one perspective of intellectual history. There were foundational changes in virtually all aspects of Chinese society. In just the first two decades of the twentieth century, the political structure, military organization, and economic composition of China all underwent a series of transformations which indicated just how deeply the foundations of China had been moved. An investigation of the intellectual activities in this period will show just how profound that shift had been. However, one factor that influenced each of the foundational changes was the reform of Chinese education. This series of reforms, beginning with the introduction of foreign language study through the establishment of the Foreign Languages Institute (T'ung-wen kuan) in Peking in 1862 to the 1907 Imperial edict authorizing a modern school system for China, were of such a sweeping range and a fundamental alteration that they really constituted a revolution. It was the success of this revolution that enabled the students of 1919 to voice China's frustrations in the May Fourth Movement.

In his study on the relationship of intellectuals to the various Chinese state structures of the modern historical era, Jerome Grieder defined three important changes in the intellectual attitudes toward reforming the nineteenth century sociopolitical structures of the late Imperial era. The first series of reforms, corresponding to the Self-Strengthening Movement (Tzu-ch'iang yüntung ), was characterized by an attitude of "chung-hsing" (restoration), a term that implied that these proposals were intended to work within the existing systems. The second series of reforms occurred as a result of the humiliating defeat in the Sino-Japanese War of 1895 and was defined by Grieder as "pien- 
fa" (changing the structure). The best known of these changes were promulgated by the Kuang-hsü emperor in the abortive 1898 Reform Movement and indicated an attempt to alter the existing system in reaction to present realities in the Chinese state. Grieder termed the third shift in the attitudes toward the existing state institutions discussed by reform-minded intellectuals, from the late 1890 s to the early 1900s, as "ko-ming " (revolution). ${ }^{6}$ This last series of reforms marks the most profound change of attitudes, because this term suggests that the intention of the intellectuals no longer was to work with the existing system but to exchange that system for a better one. ${ }^{7}$ These three series of reforms constitute the intellectual "revolution" that will be discussed.

Each one of these stages reflected the deepening concern voiced by Chinese intellectuals about the ability of their cultural heritage to respond to changing circumstances. From the beginning, it was impossible to separate efforts at educational reform from those of political reform for two reasons. The first was that educational policy is the natural interest of any state, because schools introduce the subjects or citizens of the state to cultural traditions and acceptable concepts of power and status in the society. The second reason was that politics and education were historically linked in China through a civil service examination system, founded on a thorough knowledge of Chinese classical literature. This institution had effectively limited political discussion to theories associated with the Confucian tradition and represented the only

\footnotetext{
${ }^{6}$ See Jerome B. Grieder, Intellectuals and the State In Modern China (New York: The Free Press, 1981), footnote, p. 79.

${ }^{7}$ All three of these terms were taken directly from the Classics or were based on Chinese intellectual traditions. The concept of "ko-ming" was derived from that of "tien-ming" (heaven's appointment), which first appeared in the Shu-ching(Classic of Documents), as the legitimization of the Chou dynasty. The Chou founder, King Wu, cited the "tien-ming" as the source of his authority. See James Legge's translation of "The Great Declaration" of "The Books of Chow" in The Chinese Classics Volume III. The Shoo King. (Hong Kong: University of Hong Kong Press, 1960) Part II, pp. 281-288. Therefore, if heaven legitimized imperial rule through "appointment," it could also "remove" (ko) that "appointment" (ming). In the late nineteenth century, the term, "ko-ming", was reintroduced into the Chinese language with a politicized new meaning, "revolution."
} 
avenue for achieving status and power in Imperial China. ${ }^{8}$ Therefore, to introduce even minor changes in the content of education would require fundamental alterations in existing intellectual conceptualizations, including political thought.

Due to the fact that education also served as a form of political indoctrination, the Ch'ing court was aware of and attached importance to the content and the context of instruction, and the Imperial power structure could neither easily accept nor readily agree to alterations. What began as essentially an attempt to adjust the Chinese Classical tradition to current realities became a struggle over questions relating to the very foundations of that tradition. As has been noted, the resulting foundational changes in Chinese attitudes were broad and deep, and a survey of all of these changes would be a monumental undertaking beyond the scope of this discussion. By concentrating on the process of educational reform from the 1862 establishment of the Foreign Languages Institute through the influence of Chang Chih-tung's Exhortation to Learning (Ch'üan-hsüeh p'ien) on official attitudes regarding education at the beginning of the twentieth century (1898), this study will attempt to show just how successful this intellectual revolution was.

${ }^{B}$ The correlation of social status with educational elitism was a traditional Confucian doctrine. See the Meng-tzu (Mencius), Book III, Part I, Chapter IV, in James Legge, The Works of Mencius (New York: Dover Publications, 1971), pp. 248-56. The fact that the examination system was the only way to become an official was one that concerned Confucian commentators well before the last century of Imperial China. In 1662, a noted scholar-philosopher, Huang Tsung-hsi (16101695), wrote one of the strongest indictments of the increasing reliance on literary examinations for the selection of officials in his seventh essay of the Ming-yi tai-fang lu (A Plan for the Prince). He noted that the current reliance on the civil service examination as "the only avenue leading to officialdom" was not "conducive to the recruitment of the best personnel." See the translation of this essay in Dun J. Li, [ed], The Essence of Chinese Civilization (Princeton, N.J.: D. Van Nostrand Company, Inc.,1967), pp. 169-70. 


\section{CHAPTER II}

\section{CHINESE SCHOLAR OFFICIALS AND THE STATE}

\section{TRADITIONAL EDUCATION AND THE EXAMINATION SYSTEM: THE CONCEPT OF PUBLIC STRUCTURE AND PRIVATE INSTITUTIONS}

Any discussion of the reform of an educational system must begin with a description of the existing structure. In Imperial China, traditional education had been linked to the political establishment in two important ways. The first of these was the legacy of respect for and promotion of education through the dominance of institutional Confucianism. ${ }^{9}$ The second link was the venerable Imperial civil-service examination system, which had been in place (in one form or another) since the reunification of China under the Sui (589-618) and the T'ang (618-906) dynasties. Although the examination system did not constitute the educational structure of Imperial China, it dictated what the content of traditional education would be. The acquisition of status and power lay in Imperial service and the route to Imperial service lay in the examination system, which, in turn, was based on an extensive knowledge of Confucian doctrines. Thus, the only way to advance through this system was by intensive education

\footnotetext{
${ }^{9}$ Institutional Confucianism refers to a synthesis of the teachings of Confucius with other early schools of thought, such as Taoism and the yin-yang school. Developed by Han scholars, such as Liu An and Tung Chung-shu, this synthesis was officially recognized as the state philosophy during the reign of Han Wu-ti (140-87 BCE). See Wm. Theodore de Bary, et. al., Sources of Chinese Tradition (New York: Columbia University Press, 1960), Vol. 1, pp. 148, 15. Han Confucianism also incorporated aspects of the Legalist system that had characterized the previous Ch'in dynasty; see Ping-ti Ho, The Ladder of Success in Imperial China (New York: Columbia University Press, 1980), pp. 9-10. For the importance of education in early Confucian writings, see the Lun-yü (Analects), in James Legge, Confucius: Confucian Analects. The Great Learning \& The Doctrine of the Mean (New York: Dover Publications, 1971), Book I, Chapters I, IV, VI, and XIV; and the Meng-tzu (Mencius) in James Legge, The Works of Mencius, Book VI, Part I, Chapters IX and XX. Both volumes are reprints of Legge's 1895 editions, which were the "Chinese texts, notes, and translations."
} 
in the Confucian classics. ${ }^{10}$

However, it should be stressed that the examination system was a public, bureaucratic structure which exerted strong influences over content, but did not provide an institutional structure for traditional education. At the pinnacle of the state system of an educated bureaucracy was the Hanlin Academy (Hanlin Yüan $)^{11}$, which had been founded in 740 during the T'ang dynasty as a repository of the best scholastic assistance for the Imperial court. Selection for the Hanlin Academy represented the epitome of scholastic achievement for Chinese scholar-bureaucrats. Originally established to assist the throne with translations of the Classics, the Hanlin Academy also provided the majority of Chinese education officials and examination inspectors. ${ }^{12}$ In addition to the Hanlin Academy, there was a "government schools" structure ranging downward from the Imperial capital (Kuo-tzu chien) to the provincial capitals (Shu-yüan), the prefectural capitals (Fu-hsüeh), departments (Chou-hsüeh), and villages (Shu-hsüeh, or I-hsüeh, charitable schools); however, this structure existed as an adjunct to the examination system and did not provide "public" education. $^{13}$

These "government schools" actually served as "test" centers. As the date

\footnotetext{
${ }^{10}$ For the relationship of education to the examination system, see: Ping-ti Ho, The Ladder of Success In Imperial China, Chapter 1; Joseph R. Levenson, Confucian China and Its Modern Fate: A Trilogy (Berkeley: University of California, 1968), Volume I, 16-19, 51-53; Volume II, 55-58; and Knight Biggerstaff, The Earliest Modern Government Schools in China (Ithaca: Cornell University Press, 1961), pp. 9-12. For the dominance of education by the requirements of the examination system, see John Cleverly, The Schooling of China (Sydney: George Allen \& Unwin Australia Pty. Ltd., 1985), pp. 15-20; and Ping Wen Kuo, The Chinese System of Public Education (New York: Teachers College, Columbia University, 1914), pp. 61-63.

"The Han-lin Yüan was named for the highest literary degree awarded during the T'ang dynasty. See the translation of Han-lin in Mathews' Chinese-English Dictionary, Revised American Edition, (Cambridge: Harvard University Press, 1943), p. 303. Although the degree names and the examination system was altered during subsequent dynasties, the name of the Academy remained the same.
}

${ }^{12}$ See Ping Wen Kuo, The Chinese System of Public Education, p. 42, and Cleverly, The Schooling of China, p. 22.

${ }^{13}$ Chow, The May Fourth Movement, p.12; and Ping Wen Kuo, The Chinese System of Public Education, pp. 60-61. 
of the public examinations approached, young men were required to register for their tests and pay their examination fees at the appropriate "schools"; however, these centers provided nothing beyond a place to take the examinations. Any additional expenses (travel, food, lodging, or further instruction) were the responsibilities of the examinees. With each success in the examinations, young men were required to travel further from home, until they reached the capital. Each step required payments, and it has been estimated that by the time a man had acquired the top qualification (chin-shih), the total of his expenditures could exceed 600 Taels. ${ }^{14}$

Traditional education was provided by the private sector, ranging from individual tutors to academies. ${ }^{15}$ For those who could not afford private instruction there was also a system of "popular" schools, which were established by lineage groups or by villages. These "village schools" (Shuhsüeh) were loosely connected to the government system and also represented the only true "popular" form of education. ${ }^{16}$ In 1652, a Ch'ing Imperial edict required each village to set up a school with its own funds. ${ }^{17}$ These village schools employed "teachers" to instruct the village boys in Confucian values (such as filial piety, righteousness, and loyalty) and to provide the students with a reading knowledge of 2000 characters per year for basic literacy. However,

${ }^{14}$ These expenses also included "thank-you" gifts, banquets, and tips. See Cleverly, The Schooling of China, p. 20.

${ }^{15}$ The private tutors and the teachers in the lower schools were usually young men who had not progressed beyond the first level (sheng-yüan)of the examination system. That they became "teachers" due to economic necessity rather than because of a sense of "calling" is evident from this traditional saying: "The rich never teach school, and the poor never attend one." Cited in Cleverly, The Schooling of China, p. 23. The occupation of private tutor or village school teacher was often described as plowing "with a writing brush or with an ink slab", which was a clear indication of the low esteem in which this occupation was held. See Ping-ti Ho, The Ladder of Success in Imperial China, p. 36. The low status of teachers is also discussed by Frederic Wakeman, Jr., in his The Fall of Imperial China, (New York: Macmillan Publishing Co., Inc., 1975), pp. 24-25.

${ }^{16}$ The connection came from the government requirement that each village must provide public instruction for boys in the area. See Cleverly, The Schooling of China, p. 20.

${ }^{17}$ Evelyn Sakakida Rawski, Education and Popular Literacy in Ch'ing China (Ann Arbor: The University of Michigan Press, 1979), p.33. 
basic training in arithmetic and other "vocational skills" had to be privately acquired outside of the village schools. ${ }^{18}$

The existence of these multiple systems indicated just how important education was in Chinese society. Therefore, reforming the traditional structure in China would never have been a matter of simply introducing new knowledge. There were multiple systems that had to be altered and different forms of instruction which had to be adapted in order to respond to new needs. In order to institute comprehensive change, a truly "public" educational system would have to be imposed upon several different systems.

One over-riding reason for the existence of these multiple systems was to produce the Confucian ideal of the superior man (chün-tzu), who would serve Chinese society through his personification of ethical morality and who could serve the Imperial state through a bureaucratic appointment, earned through undergoing the rigors of the examination system. Obviously, the ideal of the chün-tzu was an indication that the pursuit of knowledge was an elite occupation in traditional China. However, respect for education permeated the society from the status it conferred on the elite to the status it conferred on the common man who possessed at least functional literacy. ${ }^{19}$ Moreover, Evelyn Rawski has noted that theChinese education system did provide an overall rate of functional literacy for males in the mid-nineteenth century which has been favorably compared to that of Japan at the same time. ${ }^{20}$

The fact that there was a functional literacy rate comparable to that of

${ }^{18}$ Vocational "skills" were usually associated with traditional occupations passed down through families (bankers, carpenters, metalworkers, etc.) or were acquired through apprentice training, see Cleverly, The Schooling of China, pp. 22-23. "Mathematics" was a "vocational skill" because it was used in the calculations of artisans. For this distinction in traditional Chinese thought, see James Legge's translation in The Works of Mencius, Book VII, Part I, Chapter XLI; and Book VII, Part II, Chapter V.

${ }^{10}$ Cleverly, The Schooling of China, pp. 22-23.

${ }^{20}$ The estimated functional literacy rate for males ranges from 30 to 45 per cent and for females, from 2 to 10 per cent. See Cleverly, The Schooling of China, p. 23. For discussion of comparative literacy rates see Rawski, Education and Popular Literacy in Ch'ing China, pp. 140,151-52; and for male literacy, see her chapter, "Economic and Social Foundations of Late Imperial Culture," in David Johnson, Andrew J. Nathan, and Evelyn S. Rawski [eds], Popular Culture in Late Imperial China (Berkeley: University of California Press, 1985), p. 11. 
early Meiji Japan indicates that education was not only an ideal to be pursued by those who aspired to elite status but also a basic necessity for the functioning of Chinese economy. In addition, basic education also functioned in a political context. Even when not directly involved, the Imperial state had a important stake in education, because these institutions produced the citizens on which the state relied. This point was reinforced with an Imperial edict of 1715 , in which the K'ang-hsi emperor (r.1662-1722) noted "that the best way to influence [public] mores" was through education. ${ }^{21}$ Furthermore, since the examination system was based on a thorough knowledge of the Confucian classics, there was little incentive to study other philosophical doctrines, Chinese or foreign. ${ }^{22}$

In nineteenth-century China, another system was developing out of the sociopolitical context of the cultural contact process. In the 1842 Treaty of Nanking, which ended the Opium War, Article II guaranteed that the British residents, "with their families and establishments," would be allowed to reside in the five treaty ports, "without molestation or restraint...." Among those "establishments" were religious missions, which contained not only churches, but also hospitals and schools. Two years later, in the 1844 Treaties of Whanghsia and Whampoa, the United States and France also demanded and received official permission to construct missions in treaty ports; and, with these treaties, the Ch'ing court yielded to the establishment of yet another educational

\footnotetext{
${ }^{21}$ On education and citizens, see Ping Wen Kuo, The Chinese System of Public Education, p.3; on the edict of the K'ang-hsi emperor, see Rawski, Education and Popular Literacy in Ch'ing China, pp. 33-34. This concept linking popular education to the effective rule of the state can be found in the Analects. See Legge's translation in Confucius, Book XVII, Chapter IV.

${ }^{22}$ On the lack of independence in the thinking of the Confucian gentry, see Cleverly, The Schooling of China, pp. 20-21. In the Analects, Confucius noted the danger of studying "strange doctrines." See Legge's translation in Confucius, Book II, Chapter, XVI.

${ }^{23}$ For the text of the Treaty of Nanking, see J. Mason Gentzler, [ed], Changing China (New York: Praeger Publishers, 1977), pp. 29-31. These provisions were extended to other Western nations through a series of subsequent treaties. At least one missionary school predated the Opium War and the subsequent treaties. In 1832, the British Protestant missionary, Elijah Bridgman, had established "a small school of Chinese lads" attached to the Christian Union in Canton. Jerome Ch'ên, China and the West, Society and Culture, 1815-1937 (Bloomington, Indiana, Indiana University Press, 1979), pp. 106, 122.
} 
system, the mission schools, in China. ${ }^{24}$ However, this acquiescence on the part of the court referred only to the treaty-rights of foreigners to establish mission schools and was not an acknowledgement of the education obtained in the schools or of the Chinese graduates of those institutions. ${ }^{25}$

\section{TRADITIONAL SCHOLAR-BUREAUCRATS AS THE AGENTS OF REFORM: THE TRANSITIONAL GENERATIONS}

One of the great ironies of the late Ch'ing educational reform efforts was that they were proposed by Chinese scholar-bureaucrats who had achieved their positions through the same traditional educational structure and the same examination system they sought to change. In many of the intellectual histories of modern China, one group of men has been singled out as the "transitional generation," who brought about the profound foundational changes in the social and political institutions. This group generally includes: the advocates of political reform (K'ang Yu-wei and Liang Ch'i-ch'ao); the advocates of educational reform (Chang Chih-tung and Yen Fu); and the advocates of political revolution (Sun Yat-sen) and/or intellectual revolution (Ts'ai Yüan-pei and Chen Tu-hsiu). What characterized this group was not that they were similar in age (and definitely not in political attitudes), but that most of them had been educated under the old system. Sun Yat-sen, who had received most of his education away from China, was a notable exception. ${ }^{26}$

There were many others who could be considered members of this

\footnotetext{
${ }^{24}$ Cleverly, The Schooling of China, p. 30.

${ }^{25}$ The missionary schools would remain outside of the traditional system in Ch'ing China. See Cameron, The Reform Movement in China, 1898-1912, pp. 66-69, 84-85; and Ping Wen Kuo, The Chinese System of Public Education, pp. 136-39. The missionary schools were not incorporated into the Chinese public education system until 1929. See Ch'en, China and the West, p. 129.

${ }^{26}$ There are several good biographies on Sun. For his early education, see Harold Z. Schiffrin, Sun Yat-sen and the Origins of the Chinese Revolution (Berkeley: University of California Press, 1970), pp. 11-13; and C. Martin Wilbur, Sun Yat-sen: Frustrated Patriot (New York: Columbia University Press, 1976). p. 11-12.
} 
generation, such as the 1898 Reformer, T'an Ssu-t'ung, and the late Ch'ing radical revolutionary, Ch'iu Chin. ${ }^{27}$ Both of these young people were executed before they had been able to make substantial contributions to the educational and intellectual revolution, but their lives reflected the influence of the reforms which had already occurred. Another important member of this generation, Chang Chien, had been successful in the traditional system but had had given up the promise of a bureaucratic career in order to concentrate his educational reform efforts in the private sphere. Chang Chien became one of the new Chinese industrialists, who worked for the establishment of modern schools and practical, vocational training in his local area of Nan-t'ung, Chekiang. ${ }^{28}$

However, these individuals did not constitute the only transitional group in late Ch'ing China. Before these men had attained their intellectual maturity, another group, identified with the Self-Strengthening Movement, had already made great efforts toward the introduction of reforms to the education system. Among this group were the great Chinese "Viceroys," Tseng Kuo-fan and $\mathrm{Li}$ Hung-chang ${ }^{29}$, who were assisted by the able scholar-bureaucrat, Feng Kuei-

${ }^{27}$ Ch'iu Chin (1875 or 1877 to 1907 ) is the only Chinese woman included in this discussion of transitional generations. Her family were scholar-bureaucrats in Chekiang province and her background was unusual in that she did receive a private Classical education. Ch'iu was one of the first female "foreign-study students" (liu-hsüeh-sheng) and she became a teacher and school director in the new educational system of her home province, after her return from study in Japan (1904-1906). See Mary Backus Rankin, Early Chinese Revolutionaries (Cambridge: Harvard University Press, 1971), pp. 40-44. Although her fame is really based upon the facts that she was one of the first modern radical feminists and a revolutionary martyr, Ch'iu Chin's importance to this study is that her life was directly influenced by changes resulting from the educational and intellectual "revolution" in the late nineteenth century.

${ }^{28}$ Chang Chien (1853-1926) will be discussed in a later section. Two different views of this scholar-industrialist are: Marianne Bastid's examination of his local educational reform activities in her study, Educational Reform in Early Twentieth-Century China (Ann Arbor: University of Michigan Press, 1988); and a broader, political and intellectua,l study of Chang and his associates in Samuel C. Chu, Reformer in Modern China: Chang Chien,1853-1926 (New York: Columbia University Press, 1965).

${ }^{29}$ Although it is a Western term, the title "Viceroy" was used to describe the highest echelon of Chinese scholar-bureaucrats. See W.A.P. Martin, The Awakening of China, (New York: Doubleday, Page \& Company, 1910), pp. 220-21. In addition to their political bureaucratic positions as provincial governors or regional governor-generals, these men also occupied military positions as developers and commanders of modern, regional armies and navies. 
fen, and supported by the Manchu reformers, Prince Kung and Wen-hsiang. The efforts of theses "Self-Strengtheners", while not as spectacularly successful as their successors, helped to introduce the Ch'ing court to the concept that educational reform was necessary for the preservation of the dynasty.

In addition to the proponents of Self-Strengthening, there were three other reforming Viceroys in late Ch'ing China who could be considered members of the first transitional generation. Although they attained their positions during the initial period of Chinese educational reform activities, Chang Chih-tung, Liu K'un-i, and Yüan Shih-k'ai actually built upon earlier successes in developing their regional programs in the $1890 \mathrm{~s}$ and the first decade of the twentieth century. ${ }^{30}$

All of these "generations" were confronted by the West in a number of contexts and their interactions with foreign culture and intellectual traditions shaped their individual attitudes toward the importance of educational reforms. Their opinions were also influenced by their education in the Confucian traditions of their own society. However, their responses were varied and represented the reform segments of the traditionally educated Chinese elite.

\section{THE CHINESE INTELLECTUAL ENVIRONMENT FOR EDUCATIONAL REFORM: "INTERNAL CHAOS AND EXTERNAL TROUBLES"}

In periods of Imperial distress and disjunction, Chinese writers had often used the succinct phrase, "Nei yu, wai luan", which can be translated as "Internal distress, external disorder." In the political climate of nineteenth-century

${ }^{30}$ Chang Chih-tung (1837-1909) occupies a position somewhere between these two groups of reformers. Although he was also one of the last great "Viceroys" and a late adherent to the SelfStrengthening Movement, Chang's contributions to educational reform, which resulted in the series of Imperial edicts establishing the modern Chinese school system in the first decade of the twentieth century place him with the second generation. Liu K'un-i (1830-1902) was a contemporary political rival of Chang Chih-tung and became identified with educational reforms at about the same time that his rival did (in the 1880s). Even though he eventually wielded the power of the other Viceroys, Yüan Shih-k'ai (1859-1916) came from a very different background. $\mathrm{He}$ attained his rank through the military examination system, which paralleled the civil-service system. He joined the civil-service as a governor after the Sino-Japanese War and was considered a "reformer" for his promotion of modern military training and education in Chihli province. See Jerome Ch'ên, Yüan Shih-k'ai (Stanford: Stanford University Press,1972), p. 53; and Stephen R. Mackinnon, Power and Politics in Late Imperial China: Yuan Shih-k'ai in Beiiing and Tianjin, 19011908 (Berkeley: University of California Press, 1980), p. 138. 
China, encroachments from the West and a seemingly unending series of domestic uprisings contributed to the sense of distress and disjunction in Imperial government circles. Since it is virtually impossible to separate intellectual trends from political concerns, it would have been surprising if the philosophical environment remained unaffected. It did not. The intellectual atmosphere reflected its own "internal distress" and "external disorder."

Even though the examination system reinforced Confucian traditions over two thousand years old, this did not mean that the intellectual environment of late Ch'ing China was characterized by a uniform, monolithic Confucianism. No great philosophical system could have existed for those two millennia if it had not been somewhat flexible and open to new interpretations. As noted earlier, there had been one infusion of new elements during the Han synthesis of the first century B.C.E. and there had been a second major reorganization of the tradition during the Sung dynasty (960-1279 C.E.). The philosophy that had become such a part of the intellectual life of China had itself undergone changes and alterations. ${ }^{31}$ Therefore, even though they had passed through the structural dictates of the examination system, late Ch'ing Confucianists displayed a wide range of diversity in their approaches to the dominant philosophy of their culture.

In his short 1920 work, Intellectual Trends in the Ch'ing period (Ch'ingtai hsüeh-shu kai-lun ), Liang Ch'i-ch'ao (1873-1929) described the condition of that intellectual tradition in nineteenth-century China:

"...[W]hen an organism grows to a certain point, it becomes static and does not continue to grow, and from this stagnation comes corruption and decadence; this is the unchanging principle of things. The transformation of political systems follows this law, as do schools of thought...

"After the Chia-ch'ing and Tao-kuang periods (1796-1850), state power and control were increasingly relaxed, and the people's minds thus gradually became liberated. But, when the leisurely inertia of civil officials and flighty irresponsibility of the military went to extremes, all men of some judgment knew that a great

${ }^{31}$ For a contemporary (1911) Western assessment of Confucianism as an unchanging tradition, see Reinsch, Intellectual and Political Currents of the Far East, pp. 116-122. 
calamity was approaching." ${ }^{32}$

Liang cited as a major source of this internal stagnation in the tradition the fact that Ch'ing learning had become increasingly concerned with abstractions, rather than with concrete issues. ${ }^{33}$ As the intellectual foundation of late Imperial society, the Ch'ing school of learning was losing its vitality.

One of these "concrete issues" was the external threat to the Ch'ing intellectual environment and the Confucian tradition posed by the West, after the Opium War (1839-42). The results of the War affected the Confucian culture on a variety of levels. Not only was it a military defeat, but it was also a political debacle in the series of treaties forced on Ch'ing China by the "barbarian" victors. Furthermore, the intellectual establishment faced a cultural collision in the appeal of "Western Learning" to some Chinese intellectuals. Liang described this appeal:

“...[A]fter the 'Opium War' resolute men of purpose...considered it a profound humiliation and a singular catastrophe; they sought for ways to redeem themselves. The revival of the conception of practical studies for the service of the state burst forth like an unextinguishable, raging fire. With the lifting of the ban on oceanic communication, so-called 'Western Learning' gradually came in: first the study of industrial arts and then political institutions. Scholars hitherto had lived as if in a dark room, unaware of what was beyond it; now a window was suddenly opened, through which they peered out and discovered all sorts of radiant objects which they had never seen before. Looking back into their own room, [they saw] only depressing darkness and piled up dust. Consequently, their yearning for foreign knowledge became stronger daily and their feelings of disgust with internal [developments] daily became more pronounced." ${ }^{.34}$

\footnotetext{
${ }^{32}$ For full text, see Immanuel C.Y. Hsü's translation of Liang Ch'i-ch'ao's Ch'ing-tai hsüeh-shu kai-lun (Cambridge: Harvard University Press, 1959), Section 20: "Division in the Ch'ing School of Learning". As a reformer who became a revolutionary, Liang could have been attempting to justify his position, but other studies also show that late Ch'ing Confucianism was divided. See Joseph Levenson's discussion of the tensions in the late Ch'ing intellectual environment in his Confucian China and lts Modern Fate, Volume I, Part Two, pp. 59-94; and Jerome Grieder's introduction of the Confucian intellectual inheritance in Intellectuals and the State in Modern China, pp. 2-5.
}

${ }^{33}$ Liang Ch'i-ch'ao, Ch'ing-tai hsüeh-shu kai-lun, p. 83.

${ }^{34}$ Liang Ch'i-ch'ao, Ch'ing-tai hsüeh-shu kai-lun, p.85. Underlining is mine for emphasis. 
Liang Ch'i-ch'ao could write these words only because of historical hindsight. There would be almost two eventful decades before the "disgust with internal developments" would lead to an open interest in the "Western learning."

In the years immediately following their signing, the treaties were an irritation but not yet a catalyst for creating an intellectual climate favorable to reform. The first transitional generation of reformers were beginning their governmental service with hopes for traditional careers filling their thoughts. In his diary entry of January 1846, Li Hung-chang (1823-1901) wrote conventional words describing his joy at passing his examinations, which could have been penned centuries earlier:

"This day I completed the last of my examinations, and I know I have won the Ready-for-Office degree! I know, too, that I have passed high, for I wrote and wrote with great ease; and the classics I can repeat word for word....

"It is not given to any man to indite great classics merely because he is a graduate of the Third College...,but if he have the education and behind the education the love, and behind the love the desire and purpose, he can do work that will make his name live gloriously among his countrymen...."35

$\mathrm{Li}$ Hung-chang thus began his official career in a traditional manner during a time in Chinese history when the both the Ch'ing political and intellectual environments had been transformed from "nei yu, wai luan" to "nei luan, wai huan" or "internal disorder, external troubles."

Internal problems were mounting. At the very time that $\mathrm{Li}$ was beginning his bureaucratic career, uprisings were erupting throughout the Ch'ing Empire. As the Opium War treaties were being signed, bands of Nien rebels terrorized the populace in central eastern China and threatened Imperial control for thirty years. In western China, stretching from the deserts of the north to the hill

\footnotetext{
${ }^{35}$ The "Third College" would be the metropolitan examination, the passing of which granted the "Ready-for-Office" degree of "presented scholar" (chin-shih). Western writers have frequently equated the chin-shih with a Doctor of Letters. "Indite" is an archaic expression, meaning to express or describe in writing. For the full text of the entry, see William Francis Mannix, Memoirs of Li Hung Chang (Boston: Houghton Mifflin Company, 1923), pp. 2-4. This small volume is more a biography of Li Hung-chang with selections from his collected diaries than a straight translation of the diaries themselves. In his preface, Mannix noted that the "documents and notes" were voluminous and had been examined and translated by Major R. Emmet Roberts, a secretary to $\mathrm{Li}$ Hung-chang, and Drs. Wang and Hsiu-Tsai, The Elder, with the permission of the Imperial Government in 1909.
} 
country of the south, Moslem uprisings began in 1846-47 and plagued that region for over twenty-five years.

At the same time, southern China was the place of origin for the most disruptive episode in this phase of "internal disorder". In rural Kwangsi province, a charismatic young teacher organized a group which became known as The Society of God-Worshippers (Pai shang-ti hui ), because of their monotheistic philosophy based on salvation through the Christian God. If late Imperial society had been more stable, this group might have become just an interesting historical footnote. Instead, the Opium War had helped to create an atmosphere of frustration, dislocation, and deprivation, which, when combined with a salvationary message by a charismatic leader, resulted in a potent social rebellion. In 1851, the leadership established the Kingdom of Heavenly Peace ( $T^{\prime}$ ai-p'ing T'ien-kuo) in Kwangsi province and began a march across south and central China, which has become known as the "Taiping Rebellion" and which challenged the Ch'ing government from 1851-1865. ${ }^{36}$

The court and the bureaucracy were forced to exert tremendous efforts and to expend massive amounts of resources to deal with all of these internal problems. Rather than finding time to develop his literary aspirations in the course of his official career, Li Hung-chang found himself very involved in the Manchu government's suppression of the Taiping Rebellion. ${ }^{37}$ This series of internal disorders contributed to the disintegration of the intellectual environment of Ch'ing China that Liang Ch'i-ch'ao later noted in his 1920 work.

However, these internal disorders (nei luan) were not enough to "suddenly open" the window on Western Learning that Liang later described. It was the next phase of "external troubles" (wai huan) which became the catalyst for that change. A "window" on the West was about to forced open as a result of

\footnotetext{
${ }^{36}$ For the dates and the developments of the rebellions, see Colin Mackerras, Modern China (San Francisco: W.H. Freeman and Company, 1982), pp. 24-122 passim.

${ }^{37}$ Mannix, Memoirs of Li Hung Chang, Chapters II and III, pp. 13-71. Entries in his diary indicate that, at first, Li believed that the "God-worshippers" were supported by the Christian missionaries in China, but rather quickly came to realize that Westerners were equally disturbed by the rebellion. Both Chinese scholar-bureaucrats and Westerners quickly came to an understanding of the movement as one that was anti-establishment (specifically, anti-Manchu and anti-Confucian) rather than pro-Western.
} 
the worsening of relations between China and two of the "barbarian" powers.

In 1856, the Anglo-French War began over an incident with a Britishregistered vessel in Canton (Kwangchow) ${ }^{38}$ and the execution of a French missionary in Kwangsi province. When the combined Anglo-French forces demonstrated their military superiority once again by eventually occupying the Ch'ing capital of Peking and burning the Summer Palace north of that city, the Manchu court fled to the safety of the northeast. In October of 1860, the Ch'ing government was again forced to sign treaties and conventions with the West. Prince Kung ${ }^{39}(1833-1898)$ had been ordered to remain behind in the capital in order to represent the throne in the negotiations. Unlike those of nineteen years earlier, these treaties would permanently alter the Ch'ing intellectual climate.

The first change was a decision on the part of Prince Kung to establish an official office in the capital to deal with foreign affairs. In a January 1861 memorial, the Prince, Wen-hsiang (1818-1876), and Kuei-liang (1785-1862) ${ }^{40}$ noted that the internal problems then besetting the empire required a different response to external aggression from the foreigners than had previously been the case. The throne must at least present an appearance of compliance with external demands in order to concentrate on the more immediate internal

${ }^{38}$ The Anglo-French War is also known in Western literature as the Second Opium War or the Arrow War, after the name of the vessel that was boarded by Chinese authorities in direct violation of its British registry. Kwangchow is the Chinese name for the capital of Kwangtung province,and is better known in the West as Canton. One of the problems encountered in investigating early Western accounts of events in China is that the romanization of places and names had not been standardized. Therefore, the standard Wade-Giles (Mandarin) form for Kwangchow (which is Cantonese) is Kuangchou; Kwangtung becomes Kuangtung; and Kwangsi is Kuangsi.

${ }^{39} \mathrm{I}$-hsin was his Manchu name. He was the younger half-brother of the Hsien-feng Emperor ( $\mathrm{r}$. 1850-61) and the uncle of the T'ung-chih Emperor (r. 1861-1875), who was the son of the Hsienfeng Emperor and the redoubtable Empress Dowager (1835-1908). She is better known in Western history as Tz'u-hsi, from the first two characters of her long title. Prince Kung could do little more than agree to the demands laid down by the victorious Anglo-French forces. See the biography of Prince Kung in Volume I of Arthur W. Hummel, [ed] Eminent Chinese of the Ch'ing Period, 1644-1912 (Washington: Government Printing Office, 1943), pp. 380-84.

${ }^{40}$ Wen-hsiang was a Manchu bannerman who had obtained the advanced scholar degree and was a grand counselor to the Ch'ing court. Kuei-liang was also a Manchu grand counselor and the father-in-law of Prince Kung. These men had remained behind in Peking with the Prince to handle negotiations with the Anglo-French representatives. See biographies of Wen-hsiang and Kueiliang in Hummel, Eminent Chinese, Volume II: pp. 853-855 and Volume I: pp. 428-430. 
disorders. To further this appearance, the memorial's first recommendation was that the Ch'ing dynasty must establish a special, "temporary" office in the capital to handle the provisions of the treaties -- the Tsungli Yamen (Foreign affairs office) ${ }^{41}$ From the temporary sanctuary of Jehol, the Emperor and his court approved the memorial and reluctantly opened a political window on the Western world.

Of greater importance to the topic of educational reform was the fifth recommendation of the memorial, which incorporated one requirement of the new treaties -- that, in the future, all signatories would follow the accepted Western practice of diplomatic correspondence in the languages of the nations involved. In other words, all future correspondence between the Allied (AngloFrench) Powers and China would be in English and French and not in Chinese. The Chinese would be required to train their own official interpreters in these languages. The Ch'ing representatives were faced with the dilemma of presenting the court with what was essentially a foreign demand. Therefore, their memorial couched the demand in words that suggested a benefit to the state:

"In dealing with foreign countries, it appears necessary first of all to know their nature and temperament. Since we do not know their languages, there is complete misunderstanding. How can one hope for satisfaction?...One hears that there are merchants in Kwangtung and Shanghai who have made a special study of the written and spoken languages of Great Britain, France, and the United States. Your majesty is requested to order the governors-general and the governors of those provinces to select two honest and reliable persons to be sent from each province to the capital and to bring with them foreign books. In addition, four or five intelligent youths less than thirteen or fourteen years of age should be selected from each of the Eight Banners to study....All who master the

\footnotetext{
${ }^{41}$ The full title was the Tsung-li ko-kuo shih-wu ya-men (General civil office for overseeing the control of each nation's affairs). Although Prince Kung had proposed the office as a "temporary" measure, it remained a feature of the Ch'ing government from its establishment until it was replaced by Ministry of Foreign Affairs in 1901. Prince Kung headed the Tsungli Yamen from 1861 to 1884. Wen-hsiang and Kuei-liang were his assistants. See the text of the memorial in Ssu-yu Teng and John K. Fairbank, China's Response to the West. A Documentary Survey 1839-1923 (New York: Atheneum, 1963). pp. 47-49. Colin Mackerras uses a slightly different title: Tsung-li ko-kuo t'ung-shang shih-wu ya-men (General civil office for overseeing the control of each nation's affairs and trade), in his Modern China, p. 82.
} 
foreign languages they study will be recommended for liberal rewards; all who do not attain mastery will at length be dropped."42

As with the other recommendations, this portion of the 1861 memorial was accepted by the Imperial court and the Foreign Languages Institute ( $T^{\prime}$ 'ung-wen kuan) was established in Peking in 1862 to provide interpreters for the Tsungli Yamen. This was the second (and much larger) "window" on Western learning and the one that soon provided a change in the intellectual environment.

\section{THE POLITICAL CONTEXT OF REFORM: "SELF-STRENGTHENING" IN THE PROVINCES AND "RESTORATION" AT THE COURT}

As these dramatic events were occurring in the capital, a few Chinese officials in the provinces were also considering the promotion of "Western learning" for Ch'ing China. In 1860-61, a Soochow scholar-educator stationed in Shanghai, Feng Kuei-fen (1809-1874), compiled fifty of his essays on the current socioeconomic problems of China in his Chiao-pin-lu k'ang-i" (Remonstrations from the Chiao-pin Cottage). In the essay, "On The Adoption of Western Knowledge," Feng argued for the incorporation of selected aspects of Western learning into the Chinese education system:

"If today we wish to select and use Western knowledge, we should establish official translation offices at [Kwangchow] and Shanghai....Westerners should be invited to teach [the students] the spoken and written languages of the various nations, and famous Chinese teachers should also be engaged to teach them classics, history, and other subjects. At the same time they should learn mathematics....If we let Chinese ethics and famous teachings serve as an original foundation, and let them be supplemented by the methods used by the various

${ }^{42}$ For the full text of this section of the memorial, see Biggerstaff, The Earliest Modern Government Schools in China, pp. 94-96. For a slightly different translation, see Teng and Fairbank, China's Response to the West. A Documentary Survey 1839-1923, pp. 73-74. The Eight Banners referred to the traditional Manchu social structure of organized hereditary groupings of tribesmen, which served as military units and exercised sociopolitical functions as well. In the seventeenth century, "Banner" units were also formed from those Mongols and Han Chinese allies who had pledged loyalty to the Manchu leadership before the founding of the Ch'ing dynasty in1644. By the nineteenth century, the regular Ch'ing military forces were the Green Standard Armies, which were composed of Chinese recruits. The "Banners" continued to exist as privileged members of Ch'ing society. 
nations for the attainment of prosperity and strength, would it not be the best of all procedures?"43

In this one brief essay was the formulation which became the basis of educational reforms in the Self-Strengthening Movement. Other essays in this collection covered subjects such as: the promotion of Chinese manufacture of Western-style weapons and a discussion of ways to control "barbarian affairs".

In "On The Adoption of Western Knowledge," Feng began with a scathing denunciation of those Chinese in Shanghai and Canton who promoted themselves as "experts" on "Western affairs" (yang-wu). In view of the fact that these men most likely had gained their "expertise" through commercial or missionary contacts, Feng's comments can be seen as a reaction by a member of China's intellectual elite ${ }^{44}$ to the manner in which the "knowledge" was acquired. ${ }^{45}$ In his essay, Feng specified two important points: 1) that the sole responsibility for the teaching of "Western knowledge" must be entrusted to the "official establishment"; and 2) that the "original foundation" should continue to be the traditional knowledge found in the Chinese Classics. For these late Ch'ing scholar-officials, the issue was not one of merely introducing Western learning to students but one of controlling the process of educating those students. In Peking, the Foreign Languages Institute was officially opened with the admission of the first ten students in the summer of 1862.

Other scholar-officials were also stressing the importance of "Western learning" for its practical applications. In 1862, the Viceroy of Liang-kiang and Imperial Commissioner of military affairs in the Kiangnan, Tseng Kuo-fan (18111872), wrote in his diary of the importance of developing a Chinese method for

\footnotetext{
${ }^{43}$ For information on the publication of this important collection, see Mackerras, Modern China, p. 87. For a translation of this essay, see Teng and Fairbanks, China's Response To The West, pp. 51-52. The underlining is mine to emphasize the essential equation of the Self-Strengthening philosophy; which was the addition of selected applications, (Hsi-i or "Western techniques") to a "foundation" of Classical learning.
}

${ }^{44}$ Feng Kuei-fen had been named to the Hanlin Academy in 1840, after obtaining the chinshih degree. He also acted as assistant to Li Hung-chang in later years. See Hummel, Eminent Chinese, Vol. I, pp. 241-43.

${ }^{45}$ See Biggerstaff, The Earliest Modern Government Schools in China, pp. 13-14. 
"self-strengthening". ${ }^{46}$ In 1863, Li Hung-chang had memorialized the throne on the need to establish Foreign language-training institutions in Shanghai and Canton. ${ }^{47}$ That same year, the Imperial Censorate forwarded to the throne a memorial from a District Magistrate, Kuei Wen-ts'an, which was far-ranging in its proposals. He suggested: the additions to the examination system of such practical topics as Western geography, politics, and customs; that these examinations should be open to all knowledgeable people, from officials to commoners; and that China should send students abroad to learn Western technologies, as the Japanese had. ${ }^{48}$ Li Hung-chang's memorial was approved, and the schools were established in Shanghai (1863) and in Canton (1864). ${ }^{49}$ Citing the establishment of these schools, the throne declared that since Kuei Wen-ts'an's suggestions were already being introduced, there was no need for additional programs at the time. ${ }^{50}$

These memorials were just a few of many that were accepted by the throne as the first transitional generation began to apply Feng Kuei-fen's formula of a Classical Chinese foundation and selected Western knowledge in the development which became known as the Self-Strengthening Movement.

\footnotetext{
${ }^{46}$ Liang-kiang was the official jurisdictional designation for the Kiangnan provinces of Kiangsi, Kiangsu, and Anhwei. As military commander of this vital area, Tseng was the official in charge of the Ch'ing forces against the Taiping army. For the text of his diary notation, see Teng and Fairbank, China's Response to the West, p. 52.

${ }^{47}$ For a partial text of this memorial, see Teng and Fairbank, China's Response to the West, pp. 74-5; for a discussion of Li's reasons for proposing these schools, see Biggerstaff, The Earliest Modern Government Schools in China, p. 16.

${ }^{48}$ Biggerstaff, The Earliest Modern Government Schools in China, p. 17. A District Magistrate was a mid-level position in the Chinese bureaucracy and was frequently an entry-level position for new "presented scholar" ( chin-shih) recipients.

49 The Shanghai T'ung-wen kuan was renamed the Kuang fang-yan kuan (School for Extensive Languages) in 1869, when it was attached to the Kiangnan Arsenal. Biggerstaff, The Earliest Modern Government Schools in China, pp. 166-67. Governor-general Jui-lin established the Canton T'ung-wen kuan, and, after 1872, the students were limited to the sons of Bannermen. Biggerstaff, pp. 40-41.
}

${ }^{50}$ Biggerstaff, The Earliest Modern Government Schools in China, pp. 16-17. 
This was the first period of Chinese borrowing of foreign education. ${ }^{51}$ Since the appeal of Western learning in this period lay in technology, the early institutions were a combination of language schools and military technology institutes. In 1865, Tseng and $\mathrm{Li}$ founded the Kiangnan Arsenal in Shanghai and Tseng memorialized on its establishment. ${ }^{52}$ In 1866, the scholar and military official, Tso Tsung-t'ang ${ }^{53}$ (1812-1885) appealed to the throne for the founding of a modern naval shipyard with a Western technology facility and school at Foochow, on the southeastern Chinese coast. Tso characterized the present position of China in relation to the foreign powers in uncomplimentary terms:

"It is like crossing a river where others are rowing a boat while we are making a raft. It is like racing when others are riding on a steed while we are riding on a donkey. How is this possible? All of us are human beings, whose intelligence and wisdom are, by nature, similar; but in practice we cannot help being different. Chinese wisdom is spent on abstract things; the foreigners' intelligence is concentrated upon concrete things. Chinese take the principles of the classics as the foundation, and mechanical matters as the practical details; foreigners consider mechanical matters important, principles unimportant. Each of the two believes what it thinks is right and neither can understand the other...."54

This pessimistic assessment of the Chinese position pointed out that the Ch'ing intellectual vigor had already begun to be dominated by abstractions rather than practicalities, as Liang Ch'i-ch'ao would write in the next century. This conception of Western learning as practical was one of the reasons that the Self-Strengthening Movement proposed the inclusion of "new" education as

\footnotetext{
${ }^{51}$ French Sinologist Marianne Bastid has identified four periods of Chinese educational borrowing in her essay, "Servitude or Liberation? The Introduction of Foreign Educational Practices and Systems to China from 1840 to the Present," in Ruth Hayhoe and Marianne Bastid [eds], China's Education and the Industrialized World (Armonk, N.Y.: M.E. Sharpe, Inc., 1987), p. 4. This first period was characterized as the search for "new knowledge in specific fields", which corresponded to the "practical application" concept of the Self-Strengthening Movement. Bastid's periodization continues with: a second stage of borrowing from 1890 to 1925; a third from 1925 to 1949; and a fourth beginning in 1949.

${ }^{52}$ For a translation of this 1868 memorial, see Teng and Fairbank, China's Response to the West, p. 64-65.

${ }^{53}$ See Hummel, Eminent Chinese, Vol. II, pp. 762-67.

${ }^{54}$ For full text, see Teng and Fairbank, China's Response to the West, pp. 81-83.
} 
part of its efforts in the 1860 s and the 1870 s.

Although an Imperial edict of August 1866 granted the proponents of Self-Strengthening another victory as the new naval shipyard and technical school, the Navigation Academy (Ch'uan-cheng hsüeh-t'ang), was authorized and work was begun on its construction, the basic structure of Chinese education had not been significantly altered. For the most part, these initial institutions resulted from strong individual efforts and from the influence of Prince Kung at the court and were authorized to fill specific educational needs and in controlled circumstances. Li Hung-chang's 1863 memorial had also called for the introduction of studies in Western science and mathematics at the language schools. This part of his memorial was ignored when the schools in Shanghai and Canton were authorized. The next year, Li made another, more radical, proposal that would have altered the examination system. In a letter, he proposed that there should be a new category $\left(k^{\prime} 0\right)$ in the examinations to test technical knowledge and to promote practical, applied knowledge among scholars:

"I believe that when events reach the extreme limit, a change takes place, and once change occurs, things go smoothly. Chinese scholars and officials have been immersed in the inveterate habit of learning commentaries [on the classics] and writing fine script...so that what scholars and officials use is not what they have studied, and what they study is not what they use....[1]n China the way of manufacturing machines is for the scholars to learn the principles while the artisans learn how to run the machines, so there is no coordination of their expertise. Hence, their achievements are not combined....The most skillful craftsman, who develops his capacities to the fullest, can advance no further than becoming a chief artisan. The foreigners are different. Whoever builds a machine that is useful to the nation can become a prominent official, and for generations his family can live from his attainments and inherit his position... Whenever honor and profit are to be gained, men will exert themselves in study, exhausting their energies day and night, with the hope of achieving mastery....

"I believe that if China wishes to self-strengthen,... if we want to seek the machines...and men to make them, we might establish a special examination to recruit scholars. Seeing this as a means of attaining wealth, high position, and fame, scholars will occupy themselves with it throughout their lives. Then a 
profession can be established, there will be skill in the craft, and talents can be assembled ....".55

However, even though he had the endorsement of Prince Kung, this proposal was ignored by the throne. ${ }^{56}$

This lack of attention on the part of the throne reflected the political climate that characterized China during the decade of the $1860 \mathrm{~s}$. As noted before, the process of educational reform of the Confucian tradition would continue to reflect current political concerns. Perhaps part of the reason for this lack of attention could be explained by the fact that the state was still dealing with the "internal disorder" of rebellions. In addition, the court was also faced by the volume of reform requests proposed in such a short period of time and by the lack of revenue resources to finance any acceptable reforms. ${ }^{57}$ In his study of the intellectual environment of the mid-1860s, Kwang-Ching Liu noted a more ominous problem -- the development of factionalism at the Ch'ing court,

${ }^{55}$ This is not the entire translation of the letter, but these selections show the extraordinary changes that had occurred in the thinking of this traditionally-educated Chinese bureaucrat in the eighteen years since Li Hung-chang first attained office. The distinctions between the knowledge required by the "superior man" and the vocational skills required of the artisan were becoming blurred. See the previous footnote on this distinction in Mencius (\#15). For a translation of part of the letter, see Gentzler, Changing China, p. 75. The underlining is mine for emphasis.

${ }^{56}$ Kwang-Ching Liu, "Politics, Intellectual Outlook, and Reform: The T'ung-wen Kuan Controversy of 1867," in Paul A. Cohen and John E. Schrecker [eds], Reform in NineteenthCentury China (Cambridge: Harvard University Press, 1976), p. 91.

${ }^{57}$ The Taipings were not defeated until 1866; the Niens were finally defeated in 1868; and the Moslem uprisings were suppressed in 1873. The first memorial on "Western Affairs" (establishing the Tsungli Yamen) was in 1861 and had been followed by others in 1862, 1863, and 1864. The Ch'ing government had been presented with reparation demands after the Opium War for 21 million dollars and after the Anglo-French (Arrow) War of 6 million dollars. At the time of the Opium War, the Spanish silver dollar had become a standard currency in southern China and the reparations were most likely stated in terms of Spanish dollars. By the time of the 1860 treaties, Mexican silver dollars had replaced Spanish coinage as the standard. See Lloyd E. Eastman, Family. Field, and Ancestors (New York: Oxford University Press, 1988), p. 111. In addition, military expenses incurred by the Ch'ing government in both wars and by the continuing rebellions imposed an enormous strain on the Imperial budget. 
which was coming under the domination of the Empress Dowager, Tz'u-hsi. ${ }^{58}$

Although Prince Kung and Wen-hsiang represented the attitude for SelfStrengthening at the Imperial court, there were other, equally influential, high officials who did not share this attitude. Starting with his 1861 appointment as president of the powerful Censorate, Wo-jen (1804-1871) established his growing influence as an orthodox Neo-Confucian and the leading conservative voice in the Grand Secretariat. ${ }^{59}$ In 1865, with Wo-jen's compliance, the conservative political faction and Tz'u-hsi moved to strip Prince Kung of his influence. Even though the Prince was subsequently reinstated in most of his previous positions, his influential voice on behalf of Self-Strengthening never regained its former power at the court. ${ }^{60}$

Factionalism in the court immediately began to impact the educational reform effort. In late 1866 and early 1867, the power struggle within the court became a general intellectual dilemma for Ch'ing scholar-officials. In two

${ }^{58}$ Kwang-Ching Liu, "Politics, Intellectual Outlook, and Reform," in Reform in NineteenthCentury China, p. 90. The Empress Hsiao-ch'in was granted the title of Empress Dowager Tz'uhsi, upon the ascension of her son in 1861 as the T'ung-chih Emperor. She was a co-regent for her minor son with Hsiao-chen, Dowager Empress Tz'u-an, the consort of the Hsien-feng Emperor. For dates and titles, see Mackerras, Modern China, p. 85. The Empress Dowager had a difficult position. As a woman, Tz'u-hsi's position in traditional China was theoretically inconsequential; however, as the mother of and a regent for the young T'ung-chih Emperor, her interests lay in the preservation of the realm for her son. The differences in the specific titles for Tz'u-hsi and Tz'u-an were determined by their relationships to the T'ung-chih and Hsien-feng Emperors, respectively. As the mother of the T'ung-chih Emperor, Tz'u-hsi became the Empress Dowager; on the other hand, as the widow of the Hsien-feng Emperor, Tz'u-an was respectfully called the Dowager Empress.

${ }^{59}$ Wo-jen was a Mongol who rose to the ranks of the Hanlin Academy. See his biography in Hummel, Eminent Chinese, pp. 861-863. The Grand Secretariat was one of the Principle Offices of the Ch'ing government and influenced Imperial policy through control of the submission of bureaucratic memorials to the throne. For his conservative views, see Biggerstaff, The Earliest Modern GovernmentSchools in China, p. 20; for his orthodoxy and influence, see Kwang-Ching Liu, "Politics, Intellectual Outlook, and Reform," in Reform in Nineteenth-Century China, pp. 9091. Mary C. Wright noted that Wo-jen became the voice at court for the majority of the scholarbureaucrats, whose status depended upon the preservation of the traditional examination system. See Mary C. Wright, The Last Stand of Chinese Conservatism: The T'ung-chih Restoration, 1862-1874, (New York: Atheneum, 1967, second printing), p. 245.

${ }^{60}$ Kwang-Ching Liu, "Politics, Intellectual Outlook, and Reform," in Reform in NineteenthCentury China, p. 91. The Prince was reinstated as head of Tsungli Yamen and to his Grand Council seat. Liu's essay places the demotion of Prince Kung in the context of the political reorganization of the court. 
memorials, the Tsungli Yamen proposed more substantive reforms to the Foreign Languages Institute with the introduction of studies in mathematics and astronomy for traditional degree holders under foreign instructors. ${ }^{61}$ Although these memorials were approved and some elite scholars showed initial interest in the new studies, a conservative reaction (to educational reforms, in general, and to Western instructors, in particular) was immediately mounted. In two 1867 memorials, Wo-jen discounted any necessity for "Western techniques" in Chinese education and stressed the importance of the Confucian tradition to the well-being of the state and its officials. In his first memorial, Wo-jen deprecated the importance of the subjects and questioned the advisability of employing foreigners:

"Mathematics, as one of the six arts, should indeed be learned by scholars as indicated in the Imperial decree, and it should not be considered an unworthy subject. But according to the viewpoint of your slave, astronomy and mathematics are of very little use. If these subjects are going to be taught by Westerners as regular studies, the damage will be great... Your slave has learned that the way to establish a nation is to lay emphasis on propriety and righteousness, not on power and plotting. The fundamental effort lies in the minds of the people not in techniques....The empire is so great that one should not worry lest there be any lack of abilities therein. If astronomy and mathematics have to be taught, an extensive search should find someone who has mastered the technique. Why is it limited to barbarians, and why is it necessary to learn from barbarians?"62

The significance of this "war of words" lay not in fact that it had occurred but in the fact that the elite intellectual power structure had not yet been altered by any of the educational reforms. As previously noted, the examination system remained unaffected by reform and still constituted the only avenue to power

\footnotetext{
${ }^{61}$ The significance of these proposals lay in their attempt to induce the intellectual elite ("presented scholars" and Hanlin compilers) to enroll in the new programs. The Tung-wen kuan had been established for younger students without traditional degrees. See the previous excerpt from that memorial, pp. 19-20. As noted, the initial learning facilities for Westem studies had been established outside the traditional system and were attached to new institutions for specific training, p. 23. Equally important was the recognition that foreign instructors would have to be employed until the Chinese system could produce knowledgeable teachers in these subjects.

${ }^{62}$ For a translation of part of Wo-jen's memorial, see Teng and Fairbank, China's Response to the West, pp. 76-77. Underlining is mine for emphasis.
} 
and status for the intellectual elite.

As long as this confirmation of traditional authority remained in the hands of an Imperial court dominated by conservative political and intellectual factions, practical educational reform implementation would be piecemeal, at best. When the Empress Dowager utilized her power to present the conservative side by allowing only the circulation of Wo-jen's published memorials among the general Ch'ing bureaucracy, interest in the new "Western Learning" disappeared among Chinese elite intellectuals; and the Foreign Languages Institute's mathematics and astronomy instruction programs had to be discontinued, due to lack of qualified applicants. ${ }^{63}$

\section{THE PROBLEMS OF REFORM IN A TRADITIONAL SYSTEM: "OFFICIAL FAILURES" AND "UNOFFICIAL SUCCESSES"}

These unsuccessful struggles for reform within the system were also accompanied by proposals to utilize Western studies outside the system. In 1868, China's premier foreign-educated "returned student" (liu hsüeh-sheng), Yung Wing ${ }^{64}$, interested the Self-Strengthening leaders in the promotion of a program to send Chinese students to the United States for advanced education. Tseng Kuo-fan and Li Hung-chang memorialized the throne on this proposal in 1871 and received approval for the plan. In this comprehensive memorial, Tseng Kuo-fan proposed a timetable for Self-Strengthening, defined some of its goals, discussed some of the problems in China that reformers faced, and

\footnotetext{
${ }^{63}$ Biggerstaff, The Earliest Modern Government Schools in China, p. 21; for the political manuevering behind this development, see Kwang-Ching Liu, "Politics, Intellectual Outlook, and Reform," in Reform in Nineteenth-Century China, pp. 92-94.

${ }^{64}$ Yung Wing (1828-1912) was a Chinese youth (born Jung Hung) who received a missionary (Western) education in Macao, after he converted to Christianity. He was subsequently educated in the U.S.A. at Yale university, graduated, and returned to China in 1854, where he had contacts with both the T'ai-p'ing and the Self-Strengthening Movement leaders. See Ch'ên, China and the West, p. 151.; Grieder, Intellectuals and the State in Modern China, p. 140; and Mackerras, Modern China, pp. 81, 91. This was not the first proposal on sending students abroad for study. In his 1863 memorial, Kuei Wen-ts'an had also suggested that China send youth abroad for technical training, citing the successful example of Japan; see the discussion of Kuei's memorial, pp. 20-21, and Biggerstaff, The Earliest Modern Government Schools in China, p. 17.
} 
presented an eloquent assessment of the benefits to his country:

"Last autumn when...Kuo-fan was at Tientsin, Governor Ting Jih-ch'ang frequently came to discuss with me proposals for the selection of young and brilliant youths to be sent to the schools of various European nations to study military administration, shipping administration, infantry tactics, mathematics, manufacturing, and other subjects. It is roughly estimated that after more than ten years their training will have been completed, and they will return to China so that the Chinese can learn thoroughly the new techniques in which the Westerners are particularly strong, and then we can gradually plan for self-strengthening.....All those who have studied in foreign countries and have learned the superior techniques are to be immediately invited by academies after their return to teach the various subjects and to continue their own scholarly development....Article VII of the treaty recently concluded with the United States [1868] says that hereafter, if Chinese wish to enter the higher and lower levels of American government schools in order to learn various kinds of literature and sciences, they will enjoy equal treatment with the people of the 'most favored nation.'... To establish arsenals for manufacturing and to open schools for instruction in China is just the beginning of the struggle to rise again. To go abroad for study, to gather ideas and the benefits of greater knowledge can produce far-reaching and great results. Westerners seek knowledge for actual use. Regardless of whether they are scholars, workers, or soldiers, they all go to school to study and to understand the principles, to practice on the machines, and to get personally familiar with the work....But there are two difficulties in the trial period. One is the selection of human talent, and the other is the raising of funds...Kuo-fan and Hung-chang are deeply aware of these two difficulties...."165

That Tseng Kuo-fan had realistically assessed the problems was evident almost from the time that the memorial was approved. He had originally proposed Shanghai as the site for selecting "human talent"; however the eastern coast and the Kiangnan region proved to be difficult recruiting areas, because professional risks continued to be associated with foreign study and with expertise in "Western Learning". Since the effort to incorporate the study of mathematics and astronomy in the Foreign Languages Institute had failed, primarily due to the lack of interest among scholar-bureaucrats, traditional

${ }^{65}$ Translations of parts of the memorial can be found in Gentzler, Changing China, pp. 75-76; and Teng and Fairbank, China's Response to the West, pp. 91-93. 
studies associated with success in the examination system remained the only appropriate education for young men. Yung Wing eventually had to travel to Canton and Hong Kong to find prospective students. ${ }^{66}$

Although Tseng Kuo-fan's memorial had clearly proposed that students be sent to European countries as well as the U.S., the initial effort was directed toward study in America. Therefore, within four years (1872-1875), one hundred twenty young men had been sent to the U.S., in groups of thirty, to begin studies in scientific and mechanical arts. ${ }^{67}$ In order to assure that the youths would continue to receive a Classical "foundation" to their Western technological study, Chinese tutors accompanied each group to teach the Classics and Chinese language. The second problem, that of financing the effort, also influenced the program's progress, almost from its initiation. In 1877, even though the number of students had been reduced to one hundred eleven, the amount budgeted for their study had to be increased. ${ }^{68}$

In addition to the problems cited in his memorial, the Chinese Educational Mission (C.E.M.) encountered some unforeseen difficulties, not the least of which was the loss of an eloquent and respected advocate with the death of Tseng Kuo-fan in 1872. The conservative faction also responded to the subject of foreign study by securing the 1876 appointment of $\mathrm{Wu}$ Tzu-teng as the resident supervisor of the C.E.M. in the U.S.A. When negative reports of the students' activities began to be received by the Imperial court, Li Hung-chang wrote of his deepening concerns to Ch'en Lan-pin at C.E.M. headquarters in the U.S., from 1879-1881:

${ }^{66}$ The initial difficulties in recruiting acceptable students are discussed in Ch'ên, China and the West, pp. 151-52; and Y.C. Wang, Chinese Intellectuals and the West. 1872-1949 (Chapel Hill: The University of North Carolina Press, 1966), pp. 42-43. Wang notes that ninety percent of the students were recruited from southern China.

${ }^{67}$ This educational enterprise was called the Chinese Educational Mission (C.E.M.) and was headquartered in Hartford, Connecticut. See Biggerstaff, The Earliest Modern Government Schools in China, p. 22; and Ping Wen Kuo, The Chinese System of Public Education, pp. 67-8. Yung Wing and Ch'en Lan-pin accompanied the first group in 1872, and were the resident commissioners in Connecticut. See Mackerras, Modern China, p. 119.

${ }^{68}$ It is possible that financial constraints may have also influenced the decision to send the students to only one country. See the discussion of the expenses entailed and the increase in the Imperial budget for the Mission in Y.C. Wang, Chinese Intellectuals and the West, pp. 44-45. 
"[1879] The enterprise of sending young people to foreign countries has cost a lot of money and created numerous evils, but will after all have little actual effect. The criticisms of Chinese officials and scholars have been numerous....If all you gentlemen who are in charge of the task still cherish differing opinions and cannot control and manage it seriously, you have failed in the first attempt which was inaugurated by Tseng Kuo-fan; and you and I will also be greatly criticized by public opinion."

Perhaps Li had hoped that by mentioning the name of the honored and respected proposer of the Mission, Tseng, he could encourage the Commissioners to institute changes which might yet insure some measure of success for this initial effort However, by 1881, Li Hung-chang's re-assessment of the apparent failure of the C.E.M. rested not on a faulty vision of reform that he and Tseng had initiated but on the age and immaturity of the students, as well as on the character of the Commissioners. He wrote:

"In recent years there has been considerable criticism of Yung Wing, charging that he has laid too much emphasis upon Western knowledge, with the result that the young boys have neglected their Chinese studies...I have reviewed the case with a candid mind and feel that, since more than half the students were natives of Kwangtung who went abroad at an early age, it is probably hard for them to avoid indulging in foreign customs. Wu Tzu-teng disciplined them too severely and so compounded the trouble....." ${ }^{69}$

By 1881, official opinion in China had completely turned against continuing the Mission, and the Tsungli Yamen recalled the students home. ${ }^{70}$ The young men

\footnotetext{
${ }^{69}$ Partial texts of two letters to Ch'en Lan-pin and the 1881 comment are translated in Teng and Fairbank, China's Response to the West, pp. 94-95. As a member of the Hanlin Academy, Wu Tzu-teng must have been concerned that traditional Chinese sociocultural attitudes be maintained and may have sought to reinforce those concepts because of a perception that the young Chinese students had become influenced by a "foreign" educational atmosphere in their American schools.

${ }^{70}$ Ping Wen Kuo termed the reports as "misrepresentations" and as "false reports." See his account of the mission in The Chinese System of Public Education, pp. 67-69. Jerome Ch'ên noted that some of the reports were accurate in China and the West, pp. 151-152. Both discussions did note that the cultural climate for the Chinese students in the U.S. was affected by the rising American anti-Chinese prejudice over labor problems. In 1880, the Angell Commission began negotiations with the Ch'ing government over the limitation and eventual cessation of Chinese emigration to the U.S. See Mackerras, Modern China, p. 140. Y.C. Wang has noted that the unexpected escalation of expenses which the mission entailed for the Ch'ing state was a factor. See Y.C. Wang, Chinese Intellectuals and the West, pp. 42-45.
} 
were then distributed among the various schools with Western studies in China, such as the Foochow Naval School and the Tientsin Telegraph School (Tienpao hsüeh-t'ang), where they continued their education. ${ }^{71}$

Although the attempts to introduce new learning into the curriculum of the Foreign Languages Institute and to educate a new type of student in America were both brought to failure by turning elite intellectual opinion against them, there were other less spectacular and less "official" successes in the SelfStrengthening educational reform efforts. In 1876 and 1877, small groups of Foochow Navy Yard School graduates were dispatched to England and France for further technical studies. Among the 1877 group sent to England was Yen Fu (1853-1921), who would become one of the intellectual reformers of the next transitional generation. ${ }^{72}$ At the same time, Li Hung-chang arranged for seven army officers to be sent to Germany for advanced military studies. ${ }^{73}$

Among the less "official" successes were the efforts of a new generation of Western missionaries. In 1849, a young American Presbyterian missionary, W.A.P. Martin, had arrived in Canton and proceeded north to the missionary complex at Ningpo. ${ }^{74}$ During his early years in China, Martin would continue to pursue his interests in Chinese culture, and, after his return to China in 1862, in the promotion of scientific education. With the backing of Robert Hart, an

${ }^{71}$ The Tien-pao hsüeh-t'ang was established in Tientsin in 1880, after a memorial from Li Hung-chang. Biggerstaff, The Earliest Modern Government Schools in China, p. 22.

${ }^{72}$ Yen Fu was named Yen Tsung-kuang at birth, came from a Fukien gentry family of moderate means, and received a traditional primary education. After his father died, Yen became a scholarship student at the Foochow Navy Yard School and showed such promise that he was selected for the first Foochow group to study abroad. Yen Fu was the name he adopted for his later translations and writings. For an account of his early education, see Grieder, Chinese Intellectuals and the State, p. 149.

${ }^{73}$ Wang, Chinese Intellectuals and the West, pp. 45-46.

${ }^{74}$ W.A.P. Martin (1827-1916) was born William Alexander Parsons Martin in Indiana, educated in the sciences and theology, and always expected to become a missionary. Once in China, however, his missionary activities took a distant second place to his interest in the languages, people, and culture of China. He would spend the next half-century trying to introduce progressive education into the Chinese system. Jonathan Spence has written a very brief, readable, account of Martin in To Change China (Boston: Little, Brown and Company, 1969), Chapter 5, "Martin and Fryer: Trimming the Lamps," pp. 129-160. Martin's association with the Foreign Languages Institute is discussed in Chapter 2. 
Irishman who was the Chinese Imperial Customs Inspector-General from 1863 to 1908, Martin did some translating work for the Tsungli Yamen that eventually proved useful to Prince Kung and was rewarded with a position in the Foreign Languages Insitute as an English teacher in $1864 .{ }^{75}$ It was upon the advice of Hart and Martin that Prince Kung had "officially" attempted to introduce Western astronomy and mathematics into the curriculum of the Foreign Languages Insitute in the memorials of $1866-67 .{ }^{76}$ At the same time and with more success, Prince Kung had "unofficially" authorized Robert Hart to recruit Western instructors for the school during his 1866 furlough. ${ }^{77}$

Another Protestant missionary who was drawn to China and became involved in educational reform was an Englishman, John Fryer. ${ }^{78} \mathrm{He}$ had a varied career in China. After his arrival in Hong Kong as a Protestant missionary in 1861, Fryer studied Cantonese, became an English instructor at the Foreign Languages Insitute in 1863, moved to Shanghai for another teaching position two years later, and finally accepted a position as a scientific translator from the Chinese leadership of the Kiangnan Arsenal, a position which he held for the

${ }^{75}$ Robert Hart (1835-1911) was one of the handful of Westerners who worked loyally for the Ch'ing government in its efforts to meet the requirements of the Chinese treaties with the foreign countries. Martin's translation was Henry Wheaton's Elements of International Law. The principles in the translated work assisted Prince Kung and the Tsungli Yamen in their 1864 negotiations with the Prussians over a foreign ship confiscated in Chinese waters. See Spence, To Change China, pp. 134-35; and Grieder, Chinese Intellectuals and the State, pp. 69-70. Martin was subsequently appointed to a professorship of political economy and international law, at the Foreign Languages Institute, in 1867. See Biggerstaff, The Earliest Modern Government Schools, pp. 120-21. A further discussion of Robert Hart's contributions to Chinese educational reform is in Chapter 2.

${ }^{76}$ Kwang-Ching Liu, "Politics, Intellectual Outlook, and Reform," in Reform in NineteenthCentury China, p. 92.

${ }^{77}$ Hart was able to arrange for the services of three professors (in English, chemistry, and French) who subsequently taught at the Foreign Languages Institute. One of them, the chemistry professor Anatole Billequin, remained at the school until 1896. See Biggerstaff, The Earliest Modern Government Schools, pp. 120-21.

${ }^{78}$ John Fryer (1839-1928) was born in Kent, England; spent the years 1861-1896 in China; and died in Berkeley, California, after retiring from a professorship at the University of California (1896-1914). See Biggerstaff, The Earliest Modern Government Schools, p. 174. Jerome Ch'ên has characterized Fryer as a "rice missionary" or one who came to China for monetary and/or personal gain. See Jerome Ch'ên, China and the West, p. 102. 
next twenty-eight years. ${ }^{79}$ At the Arsenal, Fryer made tremendous contributions to the spread of Western "learning" in China with his translations of works on scientific subjects, technologies, and scientific terminology. ${ }^{80}$ This body of work constituted Fryer's official work for China. Among his great "unofficial" contributions to the reform of Chinese education were: the publication of numerous English (British and American) educational and scientific articles, which he edited for his Chinese periodical, The Scientific Magazine (K'O-chih hui-pien); the establishment of a Shanghai book depot, which marketed Chinese translations of Western books; and the 1875-76 founding of the Shanghai Polytechnic Institution and Reading Room, which was intended to bring "the Sciences, Arts and Manufactures of Western Nations in the most practicable manner possible before the notice of the Chinese."

The activities of Hart, Martin, and Fryer represent one of the central characteristics of the Self-Strengthening Movement in its efforts to introduce some educational reform into Ch'ing China. All of their activities were associated with what Marianne Bastid has called "ad hoc institutions" ${ }^{82}$, which existed outside of the traditional system. As noted before, the institutions associated with the Self-Strengthening Movement were products of individual efforts, which never were coordinated into a coherent structure and whose graduates lacked the advantages of traditional degree holders. Therefore, any

${ }^{79}$ Spence, To Change China, Chapter 5, "Martin and Fryer," pp.129-160; and Biggerstaff, The Earliest Modern Government Schools. p. 174.

${ }^{80}$ Delia Davin noted that when Liang Ch'i-ch'ao published his recommended bibliography of 329 works on Western topics, he included 119 books translated by Fryer. See Delia Davin, "Imperialism and the Diffusion of Liberal Thought: British Influences on Chinese Education," in Hayhoe and Bastid, China's Education and the Industrialized World, p. 39.

${ }^{81}$ On the K'o-chih hui-pien, see Ch'en, China and the West, p. 117; and Davin, "Imperialism and the Diffusion of Liberal Thought," in China's Education and the Industrialized World, p. 39. For the Shanghai Polytechnic Institute, see Davin, "Imperialism and the Diffusion of Liberal Thought," p.39-40; and Spence, To Change China, p. 153.

${ }^{82}$ Marianne Bastid, "Servitude or Liberation?," in China's Education and the Industrialized World, pp. 7-8. She noted that 22 of these "ad hoc institutions" existed in China by 1895. In addition to the foreign language schools, these institutions included the specific Western learning schools at the Foochow Navy Yard, the Kiangnan Arsenal, the Tientsin Telegraph School, and various other technological and military academies. 
hope for professional advancement among these students of the "new learning" lay in the reform of the examination system.

The initial recommendations for reform of the system by Li Hung-chang (1864) and the memorials by the Tsungli Yamen (1866-67) on teaching Western Learning to the chin-shih and Hanlin compilers (pien-hsiu) were both victims of the Neo-Confucian intellectual resurgence at the Ch'ing court, which coincided with the Empress Dowager's attempt to revitalize the traditional Confucian sociopolitical system in the T'ung-chih Restoration (T'ung-chih chung-hsing) of $1862-1874 .^{83}$ Although a detailed discussion of the elements of Sung NeoConfucianism that were the basis for the T'ung-chih Restoration is beyond the scope of this study, it should be noted that the philosophical concept on which this revitalization came from the writings of Chu Hsi (1130-1200) ${ }^{84}$ In his section on the duality of knowledge and action, Chu Hsi wrote:

"Knowledge and action always require each other....With respect to order, knowledge comes first, and with respect to importance, action is more important... Generally speaking, in any matter there is only one right or wrong. When the right or wrong is determined, one should choose the right and keep acting on it.... Whether a thing is right or wrong will eventually become definite of itself.... Throughout a person's handling of affairs and dealing with things, there is no point at which moral principles are not present. Although one cannot know all of them, in all likelihood he has heard the great essentials. The important point is to put into action vigorously what he has already known and make efforts to go beyond it. In this way he can go from the near to the far and from the coarse to the refined, methodically and in an orderly manner, and observable effect can be

${ }^{83}$ The dates for the T'ung-chih Restoration are the reign dates of the T'ung-chih Emperor (the son of Tz'u-hsi and the Hsien-feng Emperor). Due to the fact that he was a minor for most of his reign, Imperial policies were decided by his regents, which included his mother. His tutor was Wojen. Jerome Grieder makes the notation that the "Restoration" of the T'ung-chih Restoration was "chung-hsing", while the "Restoration" of the Meiji Restoration (1868) was "wei-hsin". See Grieder, Chinese Intellectuals and the State, p. 111. "Chung-hsing" conveys a meaning of a return to original nature and "wei-hsin" connotes renewal or to become renewed.

${ }^{84}$ See Mary Wright's section on "The Philosophic Bases of Restoration Thought," in her The Last Stand of Chinese Conservatism, pp. 59-60. 
achieved every day." ${ }^{\text {'s }}$

By returning to this philosophical basis of unchanging morality and immutable knowledge in the handling of affairs, late Ch'ing Neo-Confucians presented a strong argument for a return to Confucian traditional principles ${ }^{86}$ as the basis for the governmental and the intellectual response to the current difficulties (nei Iuan, wai huan). To an Imperial court assailed by both domestic uprisings and foreign aggressions, the Neo-Confucian concept that solutions to present problems could be found in a revitalized Chinese intellectual tradition was a powerful incentive for conservation of that tradition, rather than reformation of that tradition.

Therefore, in this political climate of Confucian retrenchment there were only opportunities for individual successes, which had been found only outside the system. However, there had been successes, and, although minor in comparison to those that were to follow, they did constitute an initial shift in the intellectual foundations of the Chinese education system. That there was not a more substantive shift was due to the fact that the traditional content of the examination system remained intact; and this would remain a barrier to substantial reforms as long as the content relied on the literary criteria.

As noted before, the civil service examination system had not been free from criticism. In 1662, Huang Tsung-hsi had criticized the reliance on the system as the only avenue for recruitment of officials. Over two centuries later, in June of 1863 , an aspiring official would voice much the same criticism of the system in his palace examination (tien-shih). His second essay was in response to a question seeking suggestions for better recruitment of bureaucrats. In an open attack on the intellectual framework of the very system that he was trying to master, the young man dismissed the current requirements as "speaking in abstractions and neglecting realities" and wrote that this situation "most definitely was not the way of the sages." The ancients "understood the

${ }^{85}$ Taken from "The Great Synthesis in Chu Hsi," translated by Wing-tsit Chan in his volume: $\underline{A}$ Source Book in Chinese Philosophy (Princeton, N.J.: Princeton University Press, 1969), pp. 60910. Underlining is mine for emphasis.

${ }^{86}$ William Ayers has termed the conservative prescription for reform as a "revival of Chinese learning, a rededication to Chinese principles of government". See William Ayers, Chang Chihtung and Educational Reform in China (Cambridge: Harvard University Press, 1971), p. 2. 
substance and comprehended the function" of the recruitment of good officials. ${ }^{87}$ This last phrase in Chinese is "ming-t'i erh ta-yung" and its author was Chang Chih-tung, the young examination candidate of 1863.

Chang's words echoed the suggestions made by Feng Kuei-fen ${ }^{88}$ in his 1861 Chiao-pin-lu k'ang-i. Where Feng had called for Confucian teachings as the "original foundation", his phrase would correspond to Chang's " $t$ '"; and when Feng had suggested the addition of "the methods used by various nations", this addition came to be identified with the concept of "yung". These two words would become identified in the Self-Strengthening Movement as the struggle to coordinate the learning of Western "methods" with Chinese educational content for the examinations. Although these words represented concepts that were not novel to the intellectual tradition of Confucian thought ${ }^{89}$, they were not well received by Chang Chih-tung's Chinese examiners. Even though he passed the examination, Chang's position on the graduates' list was near the very bottom. However, when his answers were reviewed by Tz'u-hsi, in her capacity as regent, the Empress Dowager was very impressed and subsequently improved Chang's standing on the list as the third highest chin-

${ }^{87}$ See Ayers, Chang Chih-tung and Educational Reform in China, pp. 29-35.

"It should be noted that Feng's essay, "On Western Learning," was not formally published until 1884 and was not widely distributed for official reading until 1898; Teng and Fairbanks, China's Response to the West, p.50. Chang Chih-tung's examination answer could not have been influenced by Feng Kuei-fen's essay. The famous phrase [Chung-hsüeh wei-t'i, Hsi-hsüeh wei-yung] incorporating this "t'i-yung" concept, credited to Chang Chih-tung and identified with the Self-Strengthening Movement (in retrospect), was not popularized until 1898, when Chang's Ch'üan-hsüeh p'ien (Exhortation to learning) was published. On the fact that the exact wording of the phrase never did occur in Chang's work, see Ayers, Chang Chih-tung and Educational Reform in China, pp. 50, 151. A discussion of Chang's work is in Chapter 3 of this text.

89 The intellectual tradition of " $t$ 'i-yung" can be traced back to the Sinification of Buddhist literature during the T'ang dynasty (618-906). The concept than reappeared in Sung NeoConfucianism and the thought of the influential Ming philosopher, Wang Yang-ming, who utilized the dichotomy of "t'i-yung" to describe the totality of an individual's moral character. See Ayers, Chang Chih-tung and Educational Reform in China, p.4; Grieder, Intellectuals and the State in Modern China, pp. 74-75; and Levenson, Confucian China and Its Modern Fate, Vol. I, pp. 59-60. 
shih graduate..$^{90}$ This position allowed Chang to take part in the special examination for the Hanlin Academy, which led to his appointment as a compiler (pien-hsiu) in that prestigious institution.

The examinations had a very structured form, consisting of four parts: 1) the pa-ku wen (eight-legged essay) which was a literary composition in eight parts on a specific topic from the Four Books or the Five Classics ${ }^{91}$; 2) a shih (ode) poetic composition of five lines; 3 ) a fu (prose) poetic composition of unspecified length; and 4) the lun-wen (dissertations) on a series of questions on government. ${ }^{92}$ Because this structure dictated that a thorough and precise knowledge of the nine texts of Confucianism was necessary in order to advance through the system, there was simply no opportunity for a candidate educated in nontraditional learning to display his abilities and attain status in Ch'ing China. This restriction discouraged ambitious young men and their families from investigating Western learning. ${ }^{93}$

${ }^{90}$ This could suggest that, even in 1863, Tz'u-hsi was not opposed to the subject of reform, and that she later moved against Prince Kung (in 1866-67) because of political reasons, rather than ideological differences. Ayers discusses her intervention on the question of Chang Chihtung's final standing in Chang Chih-tung and Educational Reform in China, p. 29.

${ }^{91}$ The Pa-ku wen was a stylized literary composition [wen] on a specific concept taken from Confucianism and consisted of an introductory explanation of the topic and a conclusion in eight [pa] parts or legs [ku]. For an explanation of this structure, see the excerpt from Ts'ai Yüan-p'ei's "Wo so shou chiu chiao-yü ti hui-i" ("Recollections of My Old-fashioned Education") in Gentzler, Changing China, pp.180-82. Ts'ai noted that the "eight-legs" had been reduced to "six" by the time that he was learning the structure. The Four Books (Ssu Shu) were the foundation of NeoConfucian thought. They are the Mencius; the Analects; the Great Learning, and the Doctrine of the Mean. The Five Classics ( $W u$ Ching) are the ancient texts of Confucian thought. They are the Classic of Changes, the Classic of Odes, the Classic of Documents, the Record of Rites, and the Spring and Autumn Annals, with the Tso Commentary.

${ }^{92}$ William Ayers describes the four parts of the Civil Service Examination in discussing the traditional system in his Chang Chih-tung and Educational Reform in China, pp. 11-12. These four divisions formed the structure for the first three levels of general examinations: district, prefecture, and metropolitan. Higher levels of the system, such as the tien-shih examination, consisted of essays on specific questions.

${ }^{93}$ As noted previously, all of the first transitional generation and most of the second group had achieved their rank and status through the Examination System. Therefore, it could be said that in order to be able to promote reform, these men first had to acquire positions in the traditional system. Regardless of whether they were reformers or revolutionaries, these generations were traditionally educated first. 
However, even though the previous attempts to alter the content of the examinations had been ignored (1864) or rendered ineffective (1867), the adherents of Self-Strengthening did not give up. The first step in true educational reform remained the acknowledgement of the existence of Western learning, and this acknowledgement necessitated an alteration of the examination system. ${ }^{94}$ Ten years after Prince Kung's initial failure, Li Hungchang and others mounted another series of memorials. One of the memorials to the throne came from Ch'en Hsiu-ying of the Imperial Censorate and was forwarded by the Empress Dowager for consideration by the Tsungli Yamen and the boards..$^{95}$ In May of 1877 , the decision was made to allow candidates for the provincial chü-jen degree to write an additional "dissertation" on a mathematics and science, if they so wished. ${ }^{96}$

The results of this change were neither immediately apparent nor widely evident in the system, but the importance of this change to reform efforts can be based on the facts that the first addition to the content of the examinations in virtually five hundred years had finally been made and that this addition was based on foreign learning. Even though the Imperial edict only amended the traditional examination content by testing a very specific learning application (mathematics), this was a reform initiated from within the Chinese intellectual elite and not a response to external pressures, as had been the case when the Foreign Languages Insitute was established in 1862. The significance of the

\footnotetext{
${ }^{94}$ See Kwang-Ching Liu, "Politics, Intellectual Outlook, and Reform," in Reform in NineteenthCentury China, p. 92.

${ }_{95}$ Two of the Six Boards of the Imperial government were directly concerned with the Civil Service Examinations. The Board of Civil Office or Civil Appointment was responsible for conferring the ranks attained by the successful candidates. The actual administration of the Examinations themselves was a function of the Board of Rites. In order to effect a change in the system, both Boards had to agree to any alteration in the content of the examinations and in the rank conferred for success in demonstrating ability through the new content. In addition, the Hanlin Academy, which was an independent body, would eventually have to become involved because it provided the examiner-officials, who would have to be capable of judging the new content.
}

${ }^{96}$ Chü-jen (recommended man) was the second level of degree in the traditional system. Since only those who had passed the district examinations and received the sheng-yüan (scholarlicentiate) degree could sit for the chü-jen level, the need for a thorough traditional education was preserved. See Biggerstaff, The Earliest Modern Government Schools in China, pp. 28-29. 
first successful reform initiated from within the Chinese system should not be underestimated. ${ }^{97}$ However limited, this amendment to subjects tested in the examination system marked an official acknowledgement of the fact that Western learning might have some practical uses in the selection of elite scholar-officials and might have a role in the Ch'ing educational system; and these limited acceptances represented a definite foundational shift in Chinese education.

\section{EDUCATIONAL REFORM AND THE FIRST TRANSITIONAL GENERATION: INDIVIDUAL "SUCCESSES" AND GENERAL "FAILURE"}

The alteration of the content of the examination system in 1877 marked the high tide of general structural reform in education for the first transitional generation during the Self-Strengthening Movement. Not until after China's humiliating defeat in the Sino-Japanese War of 1894-95 would another concerted effort at sweeping educational reforms completely occupy the thoughts of a group of Ch'ing bureaucrats. ${ }^{98}$ As had been the case since the beginning of reform efforts in the wake of defeat in the Opium War, successful changes in the latter years of this first generation occurred as results of individual efforts and were not part of an organized process or movement. The conservative retrenchment of the T'ung-chih Restoration had failed to provide solutions to the internal and external problems besetting Ch'ing China, and the traditional system remained relatively unaffected by proposed reforms. The first transitional generation was aging and new voices for reform were making themselves heard.

\footnotetext{
${ }^{97}$ The numbers of chü-jen candidates who were allowed to participate in the science and mathematics questions were limited by the Edict and their tests were graded separately from the others. In order to proceed to the metropolitan examinations, successful candidates had to display exceptional ability in both traditional and Western learning. See Biggerstaff, The Earliest Modern Government Schools in China, pp. 29-30. Pin Wen Kuo took a more optimistic view of this modification of the Examinations, The Chinese System of Public Education, pp. 66-67.
}

${ }^{98}$ See Cleverly, The Schooling of China, pp. 34-35; Ping Wen Kuo, The Chinese System of Public Education, pp. 66-69; and Grieder, Intellectuals and the State in Modern China, pp. 74-76. 
By 1877, Li Hung-chang was the sole representative of this first generation who was still involved with reform efforts and who retained an influential voice for reform. ${ }^{99}$ However, the focus of his reform efforts during the final stage of the Self-Strengthening Movement had shifted. Although his general intention continued to be an incorporation of selected aspects of Western learning (Hsi-hsüeh) in the Chinese educational system, the emphasis of his reforms had focused on the introduction of specific Western technologies (Hsi-i). In 1880, Li memorialized the throne on his intention to establish a special training school for telegraph operators under foreign instructors in Tientsin. ${ }^{100}$ The Telegraph Institute (Tien-pao hsüeh-t'ang) was opened in October of that year and accepted some of the students from the failed Chinese Education Mission in the United States two years later. ${ }^{101}$

In the decade of the $1880 \mathrm{~s}$, new areas of confrontation with Western colonial imperialism also began to influence the reform priorities of Li Hungchang. By 1882, he was representing the Ch'ing government in negotiations with France, resulting from their encroachments on the traditional Chinese

${ }^{99}$ Tseng Kuo-fan, Feng Kuei-fen, and Wen-hsiang had died; and although Prince Kung remained at the court, he never regained his power to influence decisions after the events of 1867. Even though he had established the Foochow Navy Yard School in 1866, Tso Tsung-t'ang was primarily an administrator and military expert, who spent most of the remaining years in directing Imperial military actions in the Western and Northwestern provinces of Ch'ing China. See his biography in Hummel, Eminent Chinese, Vol. II, pp. 762-67.

${ }^{100}$ Due to the Imperial policy of periodically shifting provinicial assignments, Li Hung-chang served in many different governorships during his long official career (1846-1901), and he attempted to implement educational reforms in each of his jurisdictions. However, his three assignments in Tientsin (1870-82, 1883-95, and 1900-1901) were an exception to this policy and the majority of the institutions Li helped to establish were in the Tientsin-Chihli area, which had been established in 1861 as an enhanced "governor-generalship". The title of the post was Governor of Chihli and Imperial Commissioner of the Northern Ports. See the chart of "Selected Governors-General in the Late Ch'ing Period," in John K. Fairbank, Edwin O. Reischauer, and Albert M. Craig, East Asia: The Modern Transformation (Boston: Houghton Mifflin Company, 1965), p. 353. It should be noted that Li's assignments were not the only exception to this policy. In the late nineteenth century, Chang Chih-tung dominated the central provinces of Hupeh and Hunan in successive assignments to the Hu-kwang governor-generalship, based in the Wuhan urban complex; and Liu K'un-i would establish his influence in his position as the Liang-kiang governor-general, centered in Nanking. For Li Hung-chang's establishments in the Tientsin area, see Biggerstaff, The Earliest Modern Government Schools in China, pp. 56-68.

${ }^{101}$ See previous footnote, number 71. 
tributary state of Annam in the Gulf of Tongking. Three years later, Li would represent his state in the signing of the Sino-France Treaty on Vietnam, after China had lost yet another military encounter with a Western power. ${ }^{102}$ This was not the only military problem faced by Ch'ing China in 1885 . Two months before he signed the Sino-French treaty, in April, Li had initialed a convention on the status of another tributary, Korea, with the Japanese representative, Ito Hirobumi. These events brought the need for a modern military to the forefront of $\mathrm{Li}$ Hung-chang's reform priorities. Within two weeks of signing the SinoFrench Treaty, he memorialized the throne on the need to establish academies for the modern training of army and navy officers. The first school in China for officer training in modern military techniques was the Military Preparation Academy (Wu-pei hsüeh-t'ang) in Tientsin, founded by $\mathrm{Li}$ and modeled after Western military training institutions. ${ }^{103}$ When Li had authorized the departure of the first group of military cadets to travel to Germany for observation and advanced military training, they came from the Tientsin Military Preparation Academy. ${ }^{104} \mathrm{Li}$ Hung-chang's concern with Chinese military preparedness in the face of the confrontational crisis with the French in Annam was shared by other younger scholar-officials, who gradually added their voices to the reform effort.

Until 1884, Chang Chih-tung concerned himself with the traditional goals of a dedicated Confucian scholar-bureaucrat -- advancement in office and

\footnotetext{
${ }^{102}$ Annam, or An-nan (Peaceful South), was the Chinese name for the former colony (until 907) and the subsequent tributary state which was centered in the Red River delta area. In 1552, the area became known by its historic Vietnamese name of Tongking, but the Chinese continued to refer to the state as Annam. For the developments leading up to the Sino-French War of 188485, see Mackerras, Modern China, pp. 142-52.

${ }^{103}$ Biggerstaff, The Earliest Modern Government Schools in China, p. 61. The Western model was the Prussian military, which had impressed the Chinese with its unification of the German states and its subsequent victory over the French in 1870-71. The Chinese purchased their first German Krupp cannon in 1871; see Françoise Kreissler, "Technical Education as a Key to Cultural Cooperation: The Sino-German Experience," in Ruth Hayhoe and Marianne Bastid, China's Education and the Industrialized World, p. 83.
}

${ }^{104}$ See the previous discussion of the first Chinese missions to Europe [p. 32]. 
administration of the policies of the throne. ${ }^{105}$ After serving as the governor of Shansi province from 1882 to 1884 , Chang was promoted to the governorgeneralship of the vital Liang-kwang region, which became the military preparation stage for Chinese forces in the Sino-French War. ${ }^{106}$ As a result of this first-hand encounter with Western military superiority, Chang became convinced of China's need for Self-Strengthening. Due to the political climate of the times, his initial interests lay in military reforms. ${ }^{107}$ Although he remained a proponent of a firm scholarly foundation in the classical heritage of the Confucian tradition for every scholar and bureaucrat, Chang Chih-tung would increasingly call for educational reforms and he would become the driving presence behind the late Ch'ing efforts to modify the system in the last decades of the dynasty.

In addition to the development of a new era of foreign military aggressions against Ch'ing China, the socioeconomic atmosphere of the state also influenced the priorities of the Self-Strengthening Movement. In 1872, $\mathrm{Li}$ Hung-chang carried on the work begun by Tseng Kuo-fan when he memorialized the throne on the necessity of establishing a steamship company to reverse the effects of foreign competition on the Chinese coastal marine transportation system. ${ }^{108}$ The next year, the Merchant Steam Navigation Company (Lun-ch'uan chao-shang chü) was founded to revitalize Chinese coastal transportation by organizing against foreign competitors. This was the

${ }^{105}$ Chang served in the Ch'ing capital as a Hanlin pien-hsiu(1863-67) and in the provinces as Director of Education in Hupeh (1867-73) and Szechwan (1873-77). In 1877, he returned to the capital and to the Hanlin Academy, where he aligned himself politically with the conservative, hawkish ch'ing-liu tang (pure-stream group), which sought to restore domestic institutional integrity and to protect the territorial integrity of the Ch'ing Empire. They scorned the diplomatic efforts of the "peace party", led by Prince Kung, Li Hung-chang, and Liu K'un-i. Ayers, Chang Chih-tung and Educational Reform in China, pp. 30-62, 65-66, 88-89.

${ }^{100}$ The Liang-kwang region comprised the provinces of Kwangtung and Kwangsi and was headquartered in Canton.

${ }^{107}$ Ayers, Chang Chih-tung and Educational Reform in China, p. 98.

${ }^{108}$ The fleet of coastal junks had shrunk drastically from 2000 in 1850 to 400 by 1870 ; figures cited in Jean Chesneaux, Marianne Bastid, Marie-Claire Bergére, China From the Opium Wars to the 1911 Revolution (New York: Random House, 1976), pp. 222-23. 
initiation of an important new concept in late Ch'ing economic development, a revolutionary institution known as an "official supervision/merchant management" (kuan-tu shang-pan) joint venture between the public and private economic sectors. ${ }^{109} \mathrm{Li}$ would follow this venture with the establishment of other significant kuan-tu shang-pan companies: the K'ai-p'ing Coal Mines in 1877; the Imperial Telegraph Administration in the years 1879-81; and the Mo-ho Gold Mines in 1887. The significance of this new form of enterprise to the process of educational reform would become more evident in the second stage of educational transformation in the endeavors of a new segment of the educated elite, the scholar-merchants.

The process of educational reform became just one aspect of a sweeping commitment to modernization on the part of a handful of influential scholarofficials in this first stage. That its successes were due more to individual efforts rather than a general political and intellectual climate favorable to systematic reform has been discussed as an indication of the personal commitments to the concept of Self-Strengthening on the part of individual members of this first transitional generation. There was another factor, however, which influenced the individual successes and the general failure of the Self-Strengthening Movement; and this factor would continue to qualify the limits of educational reform in the Imperial era. This factor was the relative difference in the power to reform between the center and the provinces and it was composed of both the intellectual attitude toward reform and the political implementation of reform. Paul Cohen has described this factor as "the distribution of power within the state-society continuum." ${ }^{110}$ This was not a phenomenon particular to late Ch'ing China; previous dynasties had experienced the periodic fluctuations of power

\footnotetext{
${ }^{109}$ Even though they had traditionally held the lowest status in Confucian society, merchants had been allowed to pursue their activities. However, the traditional Confucian scholar-official had always kept himself aloof from the pursuit of commercial profit. The fact that officials were aligning themselves with merchants in the commercial enterprises of kuan-tu shang-pan was evidence of an incipient social revolution. Li Hung-chang not only initiated the new joint venture, he invested his own funds in the Lun-ch'uan chao-shang chü. See Eastman, Family. Field, and Ancestors, pp. 101-102,192-95. For the establishment of the kuan-tu shang-pan, see Albert Feuerwerker, China's Early Industrialization (New York: Atheneum, 1970), pp. 8-10.
}

${ }^{110}$ Paul A. Cohen, "The Post-Mao Reforms in Historical Perspective," in The Journal of Asian Studies, 47 no. 3, p. 520. 
between centralized Imperial authority and decentralized regional identifications. Contemporary China has continued to experience this tension in power-sharing. ${ }^{111}$

When the political and intellectual climate at the court was dominated by Confucian retrenchment in the T'ung-chih Restoration, the Self-Strengthening Movement's reform efforts became focused in the localities where the reformers were stationed, such as Li Hung-chang's innovations in the Tientsin-Chihli area in the 1880s. Chang Chih-tung and Liu K'un-i would continue this pattern in the 1890s; and Chang Chien would concentrate his educational reform efforts in his native region of Nan-t'ung, Chekiang, in the first decade of the twentieth century.

${ }^{111}$ For the tensions between provinces and the center in traditional China, see Joseph Levenson's essay, "The Province, the Nation, and the World: The Problem of Chinese Identity," in Albert Feuerwerker, Rhoades Murphey, and Mary C. Wright [eds], Approaches to Modern Chinese Histon (Berkeley: University of California Press, 1967), pp. 268-288. For the problems of regionalism in the P.R.C., see James C.F. Wang, Contemporany Chinese Politics: An Introduction (Englewood Cliffs, N.J.: Prentice Hall, 1989, Third Edition), pp. 162-68. 


\section{CHAPTER III}

\section{BUILDING UPON THE FOUNDATIONAL SHIFT IN THE INTELLECTUAL CLIMATE}

\section{THE STRUCTURE DEVELOPED BY THE SELF-STRENGTHENING EFFORTS: SPECIALIZED INSTITUTIONS AND A TRADITIONAL BASE}

By the 1880s, the focus of the Self-Strengthening Movement reform efforts had shifted from overall systematic changes to individual, provincial projects, which had proven more successful. On a nation-wide scale, the most successful educational innovation had actually been one of the first proposals-the Foreign Languages Institute. When the school had been opened in 1862, the first language to be taught was English; and, although other foreign language classes were added in the next two decades ${ }^{112}$, the demand for English language remained dominant. ${ }^{113}$ In addition, the financial support for the school could be said to have reinforced the paramount position of English language instruction. From its inception, the Foreign Languages Institute was financed by a percentage of foreign tonnage fees collected in the treaty ports by the Chinese Imperial Maritime Customs, headed by Inspector-General (I.G.)

${ }^{112}$ French and Russian instruction were added in 1863, German language classes began in 1871, and training in Japanese was introduced in 1895.

${ }^{113}$ Two factors accounted for the demand for English language instruction. The first was the need for Chinese interpreters trained in English to translate diplomatic correspondence after the Tsungli Yamen's establishment in 1860-61. English and French were specifically required languages for Chinese diplomatic interactions after the Peking Convention of 1860 . See Robert A. Scalapino and George T. Yu, Modern China and lts Revolutionary Process (Berkeley: University of California Press, 1985), p. 45; and the discussion of Peking Convention in Chapter 1. The second (and perhaps more important) factor was the dominance of English as the language for business transactions in the Treaty Ports after the Opium War. See Davin, "Imperialism and the Diffusion of Liberal Thought," in China's Education and the Industrialized World, p. 33. 
Robert Hart from 1863-1908. ${ }^{14}$

Robert Hart's support of the Tsungli Yamen and the Foreign Languages Institute has already been noted in the discussions of the debate between Prince Kung and Wo-jen on the expansion of the curriculum of the school in 1866-67 and of his promotion of the W.A.P. Martin's translation work for the Tsungli Yamen. ${ }^{15}$ That Hart was committed to assisting the Chinese in their modernization efforts was evident from the beginning of his tenure as the I.G. In 1864, Hart negatively assessed the attitude of his predecessor, H.N. Lay, in scathing terms:

"Any one who, like Mr. Lay, thoroughly distrusts the Chinese, and believes that the only way to manage, is to drive them, can easily put together facts and arguments sufficiently specious to cause many to coincide in his views....[But] the dictatorial attitude that had proved successful with a Taoutae at a distance from the capital, turned out to be mistakenly applied when assumed towards the high functionaries at Peking....To say, that nothing is to be hoped from the present government because it does not at once turn its attention to the construction of railroads, the laying down of electric telegraph wires, the negotiation of foreign loans, and the introduction of all the appliances that exist among the people by whom it has been thrashed, and for whom it has heretofore had an ignorant contempt, is, to my mind, justified by neither logic nor common sense." 116

With this type of positive attitude toward his patron country, Robert Hart became indispensable to proponents of Self-Strengthening in the Tsungli Yamen. In his years in the foreign office, Prince Kung would frequently refer to the I.G. as "our Hart".

${ }^{114}$ Thirty percent of the fees was set for a general fund in 1862; Biggerstaff, The Earliest Modern Government Schools in China, pp. 31-32. Robert Hart was not the first foreign Inspector General of the Chinese Imperial Maritime Customs. H.N.(Horatio Nelson)Lay was the first to hold the post from its establishment in 1858 until he was replaced by Hart in 1863. See Spence's chapter, "Lay and Hart: Power, Patronage, Pay," in To Change China, pp. 93-128. Spence dates Hart's term as I.G. from 1864; while 1863 is the date cited in Davin, "Imperialism and the Diffusion of Liberal Thought," p. 37; and Mackerras, Modern China, p. 93.

${ }^{115}$ Also see Davin's essay, "Imperialism and the Diffusion of Liberal Thought," p.37.

116 "Taoutae" was Hart's romanization for "Tao-t'al" ("intendant of a circuit"--a Chinese provincial or prefectural official). See citation in Spence, To Change China, p. 111. 
In addition to his close association with the Tsungli Yamen, Robert Hart would also provide support and assistance to the educational reform effort by his interest in the development of the Foreign Languages Institute. One of the initial difficulties for the school was the turnover in the teaching staff. Part of this turnover was due to a lack of competent Chinese instructors and part of it lay in Ch'ing bureaucratic efforts to control the organization of the school. ${ }^{117}$ When the Foreign Languages Institute was established, it became necessary to employ Western missionaries for English and French instruction, as it had proven impossible to supply "the two honest and reliable persons to be sent from each province"118 to be teachers in the capital. In a later 1861 memorial, Prince Kung had noted that the inability to find Chinese teachers "well acquainted with foreign letters" had delayed the opening of the Foreign Languages Institute. His memorial continued with an explanation of the need to hire foreign instructors:

"... Now these nations at large expense employ natives of China to teach them our literature, and yet China has not a man who possesses a ripe knowledge of foreign languages and letters--a state of things incompatible with a thorough knowledge of these countries. As therefore no native candidates were sent up from Canton and Shanghai, we have no recourse but to seek among foreigners for suitable men...."119

Once Westerners were reluctantly hired, their actual employment became an issue, because Chinese scholars and officials distrusted the motivations of

117 On the need to employ foreign teachers, see Biggerstaff, The Earliest Modern Government Schools in China, p. 72. On the efforts to control the school's organization, see, Davin, "Imperialism and the Diffusion of Liberal Thought," p. 36.

${ }^{118}$ The proposal was made in Prince Kung's original memorial (1861) on the establishment of the Tsungli Yamen and the Foreign Languages Institute. See pp. 19-20 (Chapter 1).

${ }^{110}$ Cited in Scalapino and Yu, Modern China and Its Revolutionary Process, p. 45. 
foreign Christian missionaries as teachers of Chinese youth. ${ }^{120}$ However, this question of motivation did not deter Chinese authorities from hiring able missionaries as instructors; John Fryer came from a Hong Kong missionary school to teach English in Peking in 1863; and, when W.A.P. Martin was employed as an English instructor in 1864 , he was still formally associated with his American mission board. ${ }^{121}$

W. A. P. Martin, in particular, became identified with the development of the Foreign Languages Institute. When Robert Hart had arranged for Martin to do some translation work for Prince Kung, he had already known him for almost ten years. They had become acquainted in 1855, when both were studying Chinese in Ningpo, before either of them became directly involved with Ch'ing government service. After his appointment as an English instructor, Martin felt constrained by the strict controls placed on his teaching and submitted his resignation to the school officials, saying: "To be candid...the care of only ten boys who learn nothing but English is for me too small a business. It looks like throwing away my time." 122 The Chinese managed to persuade Martin to stay, with the prospect of greater influence in the future. That promise was not long delayed, for Martin was able to begin the instruction of political economy and international law in 1867 and to start teaching physics in 1869, when he also

\footnotetext{
${ }^{120}$ Jerome Ch'ên notes that this distrust was mutual and that it developed out of the combination of Chinese "bigotry" toward the Christians and the "utter blindness" of Christian missionaries toward any inherent Chinese morality. See his China and the West, pp.95-96, 110. Biggerstaff described the Chinese distrust in terms of a Chinese "disbelief that a Westerner would honestly share with Chinese students knowledge...that gave European powers military superiority over China" and of a suspicion that the Westerners might use their position to "subvert" their students' cultural heritage and loyalty. See his The Earliest Modern Government Schools in China, p. 72.

${ }^{121}$ It should be noted that the subsequent activities of both of these men demonstrated that their primary callings might have been described as the desire to gain influence through the spread of Western learning rather than through the spread of the Western gospel. Fryer informally abandoned missionary work when he accepted employment at the Kiangnan Arsenal in Shanghai in 1868. W.A.P. Martin formally resigned from the Mission Board in 1869. See Spence, "Trimming The Lamps, in To Change China, pp. 129-160.

${ }^{122}$ Quoted in Spence, To Change China, p. 136. Martin's frustration could have been related to the efforts of Ch'ing authorities to limit the foreign staff to teaching activities only. See Davin, "Imperialism and the Diffusion of Liberal Thought," p. 36.
} 
became the President of the Foreign Languages Institute. ${ }^{123}$ From 1869 to 1895 , W. A. P. Martin helped to reshape the administration and curriculum of the institution that he called "The School of Combined Learning". ${ }^{24}$ Martin devoted not only his educational and organizational abilities to the Foreign Languages Institute, but he also brought an attitude toward his patron country that echoed that of his friend, Robert Hart. In 1868, Martin wrote:

"Never have a great people been so misunderstood. They are denounced as stolid, because we are not in possession of a medium sufficiently transparent to convey our ideas to them, or transmit theirs to us; and stigmatized as barbarians, because we want the breadth to comprehend a civilization different from our own... The national mind has advanced from age to age with a stately march; not indeed always in a direct course, but at each of its great epochs, recording, as we think, a decided gain....".125

That he would devote the rest of his time in China to educational reform efforts was a clear indication that Martin truly believed what he had written.

In addition to the problem of hiring and retaining good instructors, the Foreign Languages Institute had initial difficulties in attracting capable students. Part of the recruitment problem could definitely be tied to the fact that the content of the examinations remained unaffected by educational reform in the first decade of the school's existence; and, as long as the only avenue to official status and the possibility of power remained based on traditional subject

\footnotetext{
${ }^{123}$ Martin had returned to the United States for advanced study before he began teaching physics in 1869. See Biggerstaff, The Earliest Modern Government Schools in China, pp. 32-33. Chemistry instruction was begun in 1867, when one of Robert Hart's special "recruits" Anatole Billequin, arrived from France. See the discussion in Chapter 1 on the "Unofficial Successes" of the Self-Strengthening Movement.

${ }^{124}$ Scalapino and Yu, Modern China and Its Revolutionary Process, p. 45; and Spence, To Change China, p. 139-40. Under Martin's administration, mathematics were added to the curriculum in 1869, when Li Shan-lan (1810-1882), the leading Chinese mathematician of his day, was added to the staff. After his death, the professorship of mathematics was always filled by Chinese scholars. For a negative assessment of $\mathrm{Li}$, see Grieder, Intellectuals and the State in Modern China, footnote, p. 72; for a more positive assessment, see Biggerstaff, The Earliest Modern Government Schools in China, footnote, pp. 121-22; and Wang, Chinese Intellectuals and the West, p. 32.
}

${ }^{125}$ From Martin's 1880 publication, "Hanlin Papers, Essays on the Intellectual Life of the Chinese," in Spence, To Change China, p. 139. 
matter ${ }^{126}$, ambitious and worthy young scholars would continue to pursue conventional knowledge. It was all well and good for someone of Li Hungchang's generation to advocate the "new" learning, because he had already attained his status and power in the conventional way. ${ }^{127}$

However, another influence on recruitment was the location of the Foreign Languages Institute. As previously noted, the intellectual atmosphere of the capital, dominated as it had been by the Confucian retrenchment of the T'ung-chih Restoration, did not provide a fertile ground for discovering committed and capable students. That the foreign instructors were aware of the recruitment problem was evident from this article by an instructor of English, $M$. J. O'Brien, in the North China Herald:

"...No man young enough to still have hopes of advancement in any other career would cast in his fortune with that of the College. The few who came were men who had failed in the official career -- broken down hacks to whom the stipend offered by the yamen proved dearer than their reputation.... They were looked upon by their literary brethren as renegades and traitors to the cause. They felt that they were so themselves. One of them...admitted...that outside the yamen... he represented himself as a copyist or clerk. He never acknowledged himself to be a student of the College, such a position being, to use his own expression, han-ch'en, disreputable."128

Since the capital area was unable to provide committed students, the administration of the Peking Foreign Languages Institute had to discover

${ }^{126}$ Note: the option to be tested on science and mathematics would not be offered until after the 1877 Imperial edict. See previous discussion, pp. 39-40 (Chapter 1).

${ }^{127}$ Biggerstaff makes the point that, prior to the twentieth century, virtually all of the civil service appointments were attained by mastering the traditional examination subjects. This was true for those who had also studied "Western learning." See The Earliest Modern Government Schools in China, p. 73.

${ }^{128}$ Quoted in a footnote in Biggerstaff, The Earliest Modern Government Schools in China, pp. 119-20. "Han-ch'en" is literally "hateful or vexatious subject [of the state]", which certainly indicated self-abasement on the part of the student. The article was published in 1870 . The North China Herald was a British-owned weekly that began publishing in Shanghai in 1850 and presented the views of British merchants in China. In 1864, the same company began publication of the more general, English language, North China Daily News and the Chinese language daily, Shanghai hsin-pao (Shanghai News). For a brief discussion of the growth of Western and Chinese press in treaty ports, see Grieder, Chinese Intellectuals and the State in Modern China, pp. 93-97. 
prospective scholars in other regions. The quality of the students was improved in 1867, when the Tsungli Yamen was authorized to recruit the graduates of the Shanghai and Canton T'ung-wen kuans for advanced study in Peking. ${ }^{129}$

However, the inability to recruit promising students remained a formidable barrier for the more effective use of the Foreign Languages Institute during its entire existence. The 1867 attack by Wo-jen and the conservative elite faction on the curriculum additions proposed by Prince Kung and Wen-hsiang continued to influence the intellectual climate against the school. Thirty years later, in his famous 1898 Exhortation to Learning (Ch'üan-hsüeh p'ien), Chang Chih-tung wrote of the detrimental effects of this negative attitude:

"Wen-hsiang once opened the T'ung-wen Kuan and published various books on international law and the natural sciences. If he had kept on promoting these things, he would have been able to obtain many men qualified to be sent to distant countries and thoroughly familiar with current affairs. Nevertheless, those who are careful about trifles and feel self-conscious warned one another against entering the T'ung-wen Kuan or taking examinations for secretaries of the Tsungli Yamen. Among the capital and court officials those who can discuss new knowledge are silent and unheard. Why? Because they are impeded by the erroneous ideas of all the absurd and narrow-minded scholars. Thus, even a meritorious minister (Tseng Kuo-fan) and a venerable statesman (Wen-hsiang), though celebrated for their virtue and great authority, still cannot avoid being hindered by the criticism of those who are accustomed to using the wrong to overcome the right, and so no good effect can be seen. This is pitiful and lamentable!"130

Even though student recruitment remained a problem, changes continued to be made to strengthen the quality of the education that those students received. Under the administration of Martin, the school's curriculum was broadened. From 1870, two courses of study were established at the Foreign Languages Institute: an eight-year curriculum encompassing traditional Chinese subjects, foreign language study, mathematics, sciences, international law, political economy and applied sciences; and a less popular five-year

${ }^{129}$ See Biggerstaff, The Earliest Modern Government Schools in China, pp. 32-33.

${ }^{130}$ Translated in Teng and Fairbank, China's Response to the West, p. 171; also, see Wright, The Last Stand of Chinese Conservatism, pp. 247-48. 
curriculum, which replaced foreign language study with instruction in Chinese language and Chinese mathematics but contained all of the other subjects of the longer course. ${ }^{131}$ However, since the original purpose for establishing the school had been to train interpreters, the educational stress continued to be foreign language instruction. With the appointment of Kuo Sung-t'ao (18181891 ) to the Court of St. James in 1875 , the first permanent Chinese diplomatic mission was established abroad, and these missions utilized the translating services of Foreign Languages Institute graduates. ${ }^{132}$

This employment of graduates of the school in the nascent Chinese foreign service was gratifying to those connected to the Foreign Languages Institute, because, in W.A.P. Martin's words, "the students trained in that school of diplomacy had to shiver in the cold for many a year before the Government recognized their merits and rewarded them with official appointment." ${ }^{133}$ On the other hand, this use of Foreign Languages Institute graduates in foreign legations did not result in any noticeable change of attitude toward that school among traditional Chinese scholar-bureaucrats. At the very least, they regarded foreign service positions as decided risks to the hope for an official career. The avenue for ambitious young Chinese remained tied to positions which handled

\footnotetext{
${ }^{131}$ The traditional Chinese subjects were the Classics and Chinese literature. The foreign languages were: English, French, Russian, German (1871), and Japanese (1895). Mathematics study was calculus; the sciences were physics, chemistry, astronomy, geology, and mineralogy; and the applied sciences were mechanics and theoretical navigation. Political economy was the study of economics in service of the state. See Biggerstaff, The Earliest Modern Government Schools in China, pp. 33-34.

${ }^{132}$ Biggerstaff notes that all Chinese diplomatic missions abroad were served by T'ung-wen kuan graduates in the positions of interpreters or secretaries. In the years 1876-79, permanent Chinese legations were subsequently established in Germany, France, the United States, Japan, and Russia. See The Earliest Modern Government Schools in China, pp. 148-49. Biggerstaff dates Kuo's appointment in 1876, which was probably the year that he assumed his post. Mackerras states that Kuo was appointed in the summer of 1875 and left for Britain in late 1876. See Modern China, pp. 127, 130.
} 210.

${ }^{133}$ W.A.P. Martin, The Awakening of China (New York: Doubleday, Page \& Company, 1910), p. 
internal affairs. ${ }^{134}$ Moreover, in the opinion of the majority of Ch'ing bureaucratic hopefuls (including many of the Foreign Languages Institute students) the best education for these preferred positions remained the traditional discipline of Classical studies. ${ }^{135}$

Although the interests of the majority of Chinese officials would continue to be tied to tradition, during these years there was also a small, but steady, growth in the accumulation of knowledge about Western educational methods (Hsi-chiao-fa). The most obvious source of that knowledge was the foreign instructors who became part of the faculty of the specialized "training schools" opened in the second half of the nineteenth century. ${ }^{136}$ In addition, there began to appear special studies, in Chinese, of educational methods in Western countries. One of the initial studies was published in 1873 by a German missionary, Ernst Faber. Titled "Te-kuo-hsüeh-hsiao lun-lüe" (An overview of German schools), the study was a description of the successful German system of compulsory education and professional schools and became very influential among the elite reformers. ${ }^{137}$ Seven years later, W.A.P. Martin was

\footnotetext{
${ }^{134}$ Samuel C. Chu writes that officials who were associated with Yang-wu (Foreign Affairs) were not necessarily considered "abnormal"; however, since the acceptance of a foreign service position could prove detrimental to one's career, these men might be considered to be "risktakers". This label would be an uncomfortable one for an ambitious young man seeking status in such a traditional system. See his chapter, "China's Attitudes Toward Japan at the Time of the Sino-Japanese War," in Akira Iriye [ed], The Chinese and the Japanese (Princeton, N.J.: Princeton University Press, 1980), pp. 77, 83-84.
}

\section{${ }^{135}$ Wright, The Last Stand of Chinese Conservatism, p. 248.}

${ }^{136}$ Biggerstaff lists seven types of modern educational facilities opened in this era. These categories were schools to train: 1) interpreters; 2) nautical engineers and technicians; 3) naval officers; 4) army officers; 5) telegraph operators; 6) military medical personnel; and 7) mining engineers. All of these types of institutions could be called "professional" schools. He notes that all of these were considered specialized training "outside the regular concept and system of education." See his The Earliest Modern Government Schools in China, pp. 31, 74-5. See also the earlier reference to Marianne Bastid's classification of these as "ad hoc" institutions, p. 35 (Chapter 1).

${ }^{137}$ Bastid, "Servitude or Liberation?," in China's Education and the Industrialized World, p. 9. One of the reasons for the influence of this work was the attraction of the "German Model" to the Chinese reformers after the 1871 Prussian unification of Germany, see the earlier discussion of the impression this event made on the Chinese, p. 42 (Chapter 1). The impact of this work on early Chinese reform efforts might be indicated by the fact that virtually all of the new institutions established before 1895 were specialized training schools [see previous footnote,136). 
commissioned by the Ch'ing government to undertake a two-year tour of seven foreign countries to investigate their educational systems. After his return in 1883, his materials were published as An inquiry into education in the West (Hsi-hsüeh k'ao-lüe) and became the standard Chinese reference work on foreign educational methods. ${ }^{138}$ In addition, Martin, the faculty, and the advanced graduates of the Foreign Languages Institute translated into Chinese and published more than twenty Western works on mathematics, sciences, international law and foreign legal systems. These translations were then distributed by the Tsungli Yamen to key government officials. ${ }^{139}$ A further broadening of the knowledge of the West came from the publication of diaries by Chinese envoys to the West, upon their return. One of the best known was Summing up my travels ( $Y u$-li wen-chien tsung-lüeh), published in 1884 by Hung Hsü, a Chinese diplomat who returned from Europe. In addition to the usual descriptions of Western governments and commercial structures, Hung had high praise for the educational systems, particularly the requirement of compulsory education for every boy, the variety of employment opportunities for graduates, and the broad scope of the instruction. ${ }^{140}$ When these works were added to the the translations of John Fryer in Shanghai, it became apparent that those members of the Chinese elite who were interested did not lack information on Western subjects, particularly science and technology. ${ }^{141}$

\footnotetext{
${ }^{138}$ Bastid, "Servitude or Liberation?," p. 9.

${ }^{139}$ Biggerstaff, The Earliest Modern Government Schools in China, p. 34; and Scalapino and Yu, Modern China and lits Revolutionary Process, pp. 44, 48-49.

${ }^{140}$ Ch'ên, China and the West, p. 67.

${ }^{141}$ For Fryer's contributions, see the previous discussion on pp. 34-5 (Chapter 1). Biggerstaff places the number of works attributed to Fryer at the Arsenal at eighty-seven. In addition he notes translations by two missionaries, Young J. Allen (15) and Alexander Wylie (10), and one former missionary, Carl T. Kreyer (37). The subjects of the works translated ranged from military and naval sciences to physics and astronomy. See his The Earliest Modern Government Schools in China, pp. $175,190-92$.
} 


\section{MISSIONARY-SPONSORED EDUCATIONAL ACTIVITIES: PUBLICATION, SECULARIZATION, AND THE SEARCH FOR "COMMON GROUND"}

\section{Additional sources for translations of Western works were publications} by missionary societies in China. Initially, the majority of these publications were either various translations of the Bible or religious tracts. ${ }^{142}$ From the arrival of the first Protestant missionary to China, Robert Morrison (service dates: 17921834), the publication of religious materials became an integral part of the efforts to instruct the Chinese people in the English language. When he established the first foreign school for Chinese in the British territory of Malacca in 1818, Morrison also established a methodology linking English language training, publications, and the gospel that was utilized in the subsequent founding of missions and their schools in China. ${ }^{143}$ These publications were naturally tied to the conversion activity of the missionaries. However, almost from the beginning of nineteenth-century Protestant activities in China, some missionaries also sought to spread Christian influence through the introduction of Western sciences and arts. In 1815, William Milne established the first modern periodical in Chinese, the Monthly chronicle investigating current customs (Ch'a-shih-su mei-yueh t'ung-chi-ch'uan), which was published in Malacca for distribution in China. Dr. Milne later acknowledged the importance of other Western knowledge to the spread of Christian doctrines:

"To promote Christianity was to be its primary object.... Other things, though

\footnotetext{
${ }^{142}$ Y.C. Wang notes the Protestant missionaries translated the Bible into a variety of Chinese "spoken languages" (vernacular) through romanization and characters using local idioms in the second half of the nineteenth century, in his Chinese Intellectuals and the West, p. 395. When W.A.P. Martin arrived in Ningpo, he developed a system of romanization to assist his learning that dialect and was soon publishing religious materials. See his account in Spence, To Change China, pp. 130-31. Robert Morrison, whose language skills were utilized by the British East India Company for interpreting, completed a translation of the Bible, which was published in Malacca by Milne and distributed in China, in Chesneaux, et al., China From the Opium Wars to the 1911 Revolution, pp.51-52.

${ }^{143}$ For Morrison's activities, see Peter Ward Fay, The Opium War, 1840-1842 (Chapel Hill: The University of North Carolina Press, 1975), pp. 84-89. Fay gives the date of his arrival in China as 1807. For the education methodology that Morrison formulated, see E.R. Hughes, The Invasion of China by the Western World (London: Adam and Charles Black, 1937), p. 158.
} 
they were to be treated in subordination to this, were not to be overlooked. Knowledge and science are the hand-maids of religion, and may become the auxiliaries of virtue...."144

In 1832, the Society for the Diffusion of Useful Knowledge was one of the first of missionary groups to begin publishing a Chinese-language magazine in China, the Chinese Repository, in the print shop at the Canton Factory. Regular columns in the magazine treated Western literature. However, the most important columns were either the ones devoted to sciences, such as mechanics or medicine, or those which presented the "scientific" study of traditional subjects, such as natural history, geography, and Western history, as well as theology. ${ }^{145}$ By writing on these subjects, the Chinese Repository was not only attempting to introduce new learning to its audience but was also responding to the interests of that audience. ${ }^{146}$ In addition, there were

${ }_{144}$ Quoted in Lee Ou-fan Lee and Andrew J. Nathan, "The Beginnings of Mass Culture: Journalism and Fiction in the Late Ch'ing and Beyond," in Johnson, et al. [eds], Popular Culture in Late Imperial China, p. 365. The Italics are in their citation.

${ }^{145}$ The Society was organized by J. Matheson, D.W.C. Olymphant, Elijah Bridgman, and Charles Gutzlaff. There is some discrepancy about the initial publication date of the magazine. Ch'ên gives the founding date as 1834; see his China and the West, p. 116. The starting date of 1832 is given for the Chinese Repository in Fay, The Opium War, 1840-1842, pp. 89-92; and the dates for the Chinese Repositoryare 1832-1851 in Chesneaux et al., China From the Opium Wars to the 1911 Revolution, p. 52. Some of these articles most likely presented the prevalent trends in the development of the Western intellectual tradition. The first half of the nineteenth century was a time of intellectual vitality in Europe. A brief list of some contemporary scientific scholarship that may have influenced the articles in the the Society's magazine included: in 1785, James Hutton had published The Theory of the Earth, which became a basis for the development of modern geology; Leopold von Ranke modernized Western historiography with the 1824 publication of his The Histories of the German and Roman Peoples; the Christian Socialist, Count Claude Henri de Saint-Simon, published The New Christianity in 1825; Auguste Comte published his six-volume Cours de Philosophie Positive, describing the importance of natural law and reason in the development of society, from 1830-42; Herbert Spencer extended Comte's ideas in his Social Statics (1850) and First Principles, laying the basis for the theory of "social" evolution; Michael Faraday demonstrated electromagnetic induction in 1831; and Charles Darwin's The Origin of the Species was published in 1859. This is merely a small sampling of the writings to point out the range of inquiry in those years and to indicate the influence of science on different aspects of European thought.

${ }^{146}$ Suzanne Wilson Barnett writes that these topics were a response to Chinese publications, such as the "geographical" writings of Commissioner Lin Tse-hsü and Hsu Chi-yü; see her "National Image: Missionaries and Some Conceptual Ingredients of Late Ch'ing Reform," in Cohen and Schrecker, Reform in Nineteenth-Century China, p. 165. [See footnote 147, following]. 
publications of secular works, such as English history, astronomy, and arithmetic and secular literature with a religious theme, such as an 1842 Chinese edition of Pilgrim's Progress. Publications such as these helped to introduce Western knowledge and intellectual attitudes to Chinese scholar-officials in the areas of the country where they were distributed. ${ }^{147}$

Protestant missions were supported by faithful congregations back home, which were made up of the growing Western middle class. The interests of this class reflected the social issues of the societies in which they lived and worked. As the intellectual atmosphere influencing the congregations in midnineteenth century Europe (and post-Civil War United States) was imbued with a faith in scientific progress and rationalism, the philosophical attitudes of the missionaries they supported also began to reflect these ideas. In 1863 London, The Times ran a series of articles on the controversy surrounding the primary purpose of missionaries; this controversy centered around the question of whether the initial work of missionaries was to introduce Western civilization or to spread religion. The decision that introducing the benefits of civilization should precede the teaching of religion then spread to mission societies in the United States. ${ }^{148}$ By 1877, the Conference of the Protestant Missions in Shanghai had noted this shift in the agenda, and the secularization of missionary education was advocated and instituted. ${ }^{149}$

${ }^{147}$ One example of this use of information published by missionaries was the 1843 publication of Wei Yuan's Hai-kuo t'u-chih (Illustrated gazeteer of maritime countries), which was partly based on materials gathered by his friend Lin Tse-hsū, while serving in Canton. Among those materials were commercial treatises, geographical descriptions, and missionary papers. Wei Yuan (17941856) and Lin Tse-hsü (1785-1850) were members of the 'contemporary affairs' group, bureaucratic reformers who stressed Confucian ethical morality in state relations. See Chesneaux, et al., China From the Opium Wars to the 1911 Revolution, pp. 74-5. These authors give the title of Wei Yuan's book as "Atlas of the Countries Beyond the Seas" but do not provide the Chinese. Mackerras provides the Chinese for the title and the correct translation in his Modern China, p. 27. Wei Yuan's book was full of inaccuracies and was outshone by the 1849 publication, Ying-huan chih-lueh (A short account of the maritime circuit), by Hsu Chi-yũ (1795-1873), who compiled his information through contacts with foreigners in the treaty ports, including American missionary, David Abeel. See Grieder, Chinese Intellectuals and the State in Modern China, pp. 54-55.

${ }^{148}$ See the discussion in Hughes, The Invasion of China by the Western World, pp. 68-70.

${ }^{149}$ For the importance of the 1877 Shanghai Conference and secular influences, see Ch'ên, China and the West, pp. 96-99, 116-21. For the secularization of missionary education, see Cleverly, The Schooling of China, pp. 31-32. 
Ten years after the Shanghai Conference, in 1887, the Reverend Alexander Williams would establish another Christian publishing organization, The Society for the Diffusion of Christian and General Knowledge (S.D.K.), that would have the express purpose of presenting Western thought and Christian principles from a Chinese "literati" perspective. ${ }^{150}$ Although the previous publications had also presented foreign knowledge, they had been written from a Western Christian perspective and were intended for both a Western missionary and Chinese audience. ${ }^{151}$ This shift in perspective from Western Christian to Chinese elite was a further indication that missionaries were incorporating new methods into their educational activities in order to present a broader range of ideas.

Although Protestant missionaries had been active in China for over half a century, their contacts had been largely confined to their activities among the poor and the students of their mission schools in the treaty ports. ${ }^{152}$ Since the primary purposes of these early institutions had been to proselytize, the instruction provided was designed for that purpose. ${ }^{153}$ As noted before, many of these early publications associated with the missions had been written in local vernacular styles. ${ }^{154}$ While this might have made it easier to communicate Christianity to the less well-educated Chinese public, the use of vernacular language restricted the ability of the missionaries to appeal to elite readers, for one of the important social structural barriers in traditional China was the ability to communicate in "official" language, the literary language (wen-yen) of the

\footnotetext{
${ }^{150}$ Scalapino and Yu, Modern China and Its Revolutionary Process, p. 80. See the further discussion of the S.D.K. activities at the end of this chapter.

${ }^{151}$ On the perspectives of the early missionary publications, see Suzanne Wilson Barnett, "National Image: Missionaries and Some Conceptual Ingredients of Late Ch'ing Reform," in Cohen and Schrecker, Reform In Nineteenth-Century China, pp. 160-69.

${ }^{152}$ Cleverly notes that only "free food, lodging and clothes kept the schools operating", in his The Schooling of China, pp. 30-31. In his discussion of W.A.P. Martin's early missionary work in Ningpo and Peking, Spence writes that "most of his pupils were from the poorest classes"; see Spence, To Change China, pp. 132-33.
}

${ }^{153}$ Ch'ên, China and the West, p. 122.

${ }^{154}$ See footnotes 139 and 140 on the use of vernacular language in missionary literature. 
Chinese Classics. ${ }^{155}$

Therefore, if the missionaries could not establish a common ground with the scholarly elite through the use of wen-yen in their publications, they might be able to widen the appeal of their instruction and information through a change in the content of the instruction. This was a powerful inducement for secularizing education in order to gain influence among the Chinese scholarly elite; and, the Conference noted that, since science was based on rationalism rather than ethical morality, it could prove the common ground for developing relationships with Chinese elite reformers. ${ }^{156}$

One common ground that already existed between Chinese and missionaries was the introduction of Western medical practices, which had accompanied the pre-Opium War establishment of Protestant missions. One of the early successes for medical missionaries in China was in the treatment of eye diseases, which encouraged an American, Dr. Peter Parker, to open the first Western medical facility in China, the Ophthalmic Infirmary of Canton in $1835 .{ }^{157}$ Although he had been trained as a general surgeon, Dr. Parker reported that the specialty of ophthalmic surgery was the most logical choice for the introduction of Western medicine. In his first quarterly report to the American Mission Board, Parker wrote "Diseases of the eye were selected as those the most common in China, and being a class in which the native practitioners are most impotent, the cure, it was supposed, would be as much appreciated as any other." 158 Three years later in the same city, he formed the Medical Missionary Society with: Elijah Bridgman, an American missionary and educator; Thomas

${ }^{155}$ Evelyn S. Rawski, "Problems and Prospects," in Johnson, et al., Popular Culture in Late Imperial China, p. 400.

${ }^{156}$ Ch'ên, China and the West, p. 98.

${ }^{157}$ Hughes, The Invasion of China, p. 222; and Ch'ên, China and the West, p. 129. Thomas Colledge had opened an eye clinic for Chinese patients in the late $1820 \mathrm{~s}$, but that clinic was located in the Portuguese colony of Macao. He closed it in 1833, when he moved to Canton. See Fay, The Opium War, 1840-1842, pp. 92-93.

${ }^{158}$ This wording seemed to indicate that Dr. Parker's intention was to find a way to gain credibility with the Chinese, by complementing rather than confronting traditional medicine. The quotation is from the 1836 Chinese Repository, cited in Spence, To Change China, p. 42. 
Colledge, a former senior surgeon of the British East India Company; and William Jardine, a former surgeon's mate on a Company ship. ${ }^{159}$ Parker acknowledged that acceptance of Western medicine assisted the primary work of the missionaries:

"Viewing with peculiar interest the good effects that seem likely to be produced by medical practice among the Chinese especially as tending to bring about a more social and friendly intercourse between them and foreigners, as well as to diffuse the arts and sciences of Europe and America, and in the end to introduce the gospel of our Saviour,...we have resolved to attempt the foundation of a society, to be called the Medical Missionary Society in China." ${ }^{160}$

This Society helped to support Western medical institutions and to train Chinese students in Western medicine. This combination established the future pattern for developing medical missions in China, one that linked treatment and training. ${ }^{161}$

One aspect of the medical treatment and training pattern resulted in educational opportunities for Chinese girls. The need for nurses to work with hospital patients had resulted in a decision to train medical personnel. The growth of Western medical institutions created a problem when female patients began to come for treatment. Due to Chinese cultural traditions, such as the strict separation of the sexes in public, there was a need to train male nurses for male patients and female nurses for female patients. ${ }^{162}$ In addition, the introduction of female education in missionary schools produced young women

\footnotetext{
${ }^{159}$ Elijah Bridgman had founded the Bridgman school. (See footnote 23). Thomas Colledge had become the senior surgeon to the British factory in Canton. William Jardine was one of the most successful private merchants in the "Canton Trade." He became famous with the establishment of Jardine, Matheson and Company, with fellow Scotsman, James Matheson. For the founding of the Medical Missionary Society, see Ch'ên, China and the West, p. 129. For a discussion of the backgrounds of Colledge and Jardine, see Fay, The Opium War, pp. 44-45, 9294.

${ }^{160}$ Spence, To Change China, p. 46.

${ }^{161}$ Ch'ên, China and the West, pp. 129-30. One of the first Chinese doctors trained in Western techniques, Yu Ho-ch'uan, helped to spread the use of vaccinations throughout China. See Chesneaux et al., China From the Opium Wars to the 1911 Revolution, p. 76.

${ }^{162}$ Hughes, The Invasion of China By the Western World, pp. 225-26.
} 
who had little opportunity for any vocation in traditional society. Since the options for further learning beyond elementary training in girls' mission schools (such as the one founded by Miss Aldersey in Ningpo in 1844) were unavailable in traditional society, young women sometimes took the opportunity to study for a non-traditional career in medicine. ${ }^{103}$ As a contrast to the unsuccessful government-sponsored Chinese Education Mission for boys, between the years 1881 and 1892, four young women were sponsored by missionary groups to study medicine in the United States, where they successfully completed their studies and became the first women doctors in China. ${ }^{164}$

Medicine provided an early access to Chinese bureaucrats for the missionaries, when the Imperial Commissioner Lin Tse-hsü contacted Dr. Parker in 1839 about a personal health problem and subsequently praised the doctor's hospital in public. ${ }^{165}$ Forty years later, in 1879, another Western doctor assisted another Chinese bureaucrat with a medical problem, when Li Hungchang's wife was cured of some unnamed malady by a Western doctor in Tientsin. Li's gratitude was expressed by a personal donation toward the

${ }^{163}$ In her discussion of Chinese female literacy rates, which were estimated at between one and ten percent at the beginning of the nineteenth century, Evelyn Rawski notes that the estimates would vary from rural to urban and from region to region. As an example of regional variance, she cites the female literacy rate for Chinese immigrants to Hawail of twenty-five percent as an indication that literacy was higher in Kwangtung, which was the province of origin for the majority of Chinese immigrants to Hawaii in the nineteenth century. Since this region had had the longest interaction with the missionaries, there might be a correlation between missionary schooling and female literacy rates. See her Education and Popular Literacy in Ch'ing China, pp. 6-7. On early missionary schools for girls, see Cleverly, The Schooling of China, p. 30. As was the case with the male students of missionary schools, most of the girls were also from the poorest classes of Chinese society. One interesting example was the school established for "beggar girls" in Peking in 1864, by Mrs. Eliza Bridgman. Jerome Ch'ên writes that the 1895 renaming of the school as the Bridgman Academy, when the school added a secondary education level, indicated that the girls now came from "good families". See China and the West, p. 123. On the new medical careers for Chinese women, see Hughes, The Invasion of China By the Western World, p. 226.

${ }^{164}$ Wang, Chinese Intellectuals and the West, p. 49.

${ }^{165}$ The medical problem was a hernia and the personal nature of Lin Tse-hsü's complaint presented some unique problems in medical procedure for Dr. Parke; see the description of this procedural process and its effects in Spence, To Change China, pp. 47-48. 
founding of the Isabella Fisher Hospital for Women in that city. ${ }^{166}$ However, these contacts were usually confined to the treaty ports and were very rare occasions.

\section{TREATY PORTS AND THE INTRODUCTION OF WESTERN LEARNING: NEW INTERACTIONS AND NONTRADITIONAL INTELLECTUALS}

In 1842, Article II of the Treaty of Nanking did more than merely "open" five coastal ports to British mercantile activities. By permitting the permanent residence of British merchants, their families, and establishments in these cities, however reluctantly, the Ch'ing court was opening five "windows"167 on a different cultural tradition. Twenty years later, after the Convention of Peking ratified the Treaty of Tientsin, eleven more "windows" on the West were forced open. However, in the conventional attitudes of the Ch'ing leadership, their initial acquiescence to foreign residence in the cities of the treaty-port system might have represented a compromise between the lesser of two evils.

From the establishment of the dynasty in 1644, the core of the Manchu power system was the developed area that encompassed the Yangtze valley and the North China plain; and the coastal provinces and their maritime ports might have been considered as "peripheral" to this core. ${ }^{168}$ Therefore, to allow the barbarians to reside in these peripheral areas could be rationalized as preferable to the possibility of a greater disaster, which might have been the imposition of foreign control over all or part of the Middle Kingdom. By allowing

${ }^{166}$ Ch'ên, China and the West, p. 131.

${ }^{167}$ The "window" metaphor is Liang Ch'i-ch'ao's and one that is particularly appropriate to this discussion of the developing interactions between Chinese traditions and Western learning in the treaty ports. See the previous citation from Liang Ch'i-ch'ao's 1920 Ch'ing-tai hsüeh-shu kai-lun, [p. 15, Chapter 1].

${ }^{166}$ See John E. Wills, Jr., "Maritime China from Wang Chih to Shih Lang," in Jonathan D. Spence and John E. Wills, Jr. [eds], From Ming To Ch'ing: Conquest, Region and Continuity in Seventeenth-Century China (New Haven: Yale University Press, 1979), p. 204-205. Wills makes the point that the southeastern coast and the southern provinces were the last regions of Ming China to be brought under Ch'ing domination in 1683. The concept of a Chinese center from which the civilizing force of civilization reached out is very old. See Legge, The Works of Mencius Book VII, Part I : 21, and Part II : 4. 
the foreigners to settle in what was considered the outer reaches, the ManchuChinese center might have decided that they were actually keeping the barbarians at arms length.

In addition, the political structure of the Ch'ing government was one that initially had been characterized by a strong central administration imposed at the beginning of the dynasty which had gradually become attenuated by the time that the Western nations were moving into the peripheral areas. ${ }^{169}$ In the terms of a cultural structure, Paul Cohen has noted that the treaty ports formed part of a "littoral" culture that had developed somewhat separately from the traditional interior of China. ${ }^{170}$ This littoral culture had historically served as a border checkpoint or gate between the Middle Kingdom and the maritime tributary states. As such, these areas could be considered cultural outposts that could keep unwanted influences separate from the Chinese core.

If the treaty ports themselves were considered to be part of the Chinese border, the foreign enclaves for which the treaties provided could not be so considered. One aspect that was different was the issue of extraterritoriality, which effectively removed certain sections of the ports from Chinese legal and political jurisdiction. Although this may have seemed a small price to pay for the preservation of the inherited tradition, in essence, foreign enclaves under foreign jurisdiction offered a special opportunity for the introduction of Western learning to the Chinese inhabitants. Increasingly, during the latter half of the nineteenth century, the demand for foreign-language training grew among the more affluent Chinese families as an avenue for the advancement of their sons in new treaty-port business careers. ${ }^{171}$ Among those careers were possible positions in foreign firms, in Chinese firms established to deal with maritime enterprises, in the Imperial Customs Service or the Chinese Imperial Postal Service (under the control of the Customs), or in the Christian missions and the

\footnotetext{
${ }^{169}$ See Frederick E. Wakeman, Jr., "China and the Seventeenth-Century Crisis," in Late Imperial China, Vol. 7, No. 1 (June 1986), p. 22. Also refer to the discussion of traditional powersharing tensions between provinces and the center on pp. 44-45 [Chapter 1].

${ }^{170}$ See his "The New Coastal Reformers," in Cohen and Schrecker, Reform in NineteenthCentury China, pp. 255-264.
}

${ }^{17}$ Cleverly, The Schooling of China, pp. 31-32. 
secularized schools attached to these mission establishments. ${ }^{172}$ When these possibilities were compared to the only official career avenue in traditional China, there was an immediate recognition of both a wider range of opportunities and a changing situation for young educated Chinese men in the treaty ports. ${ }^{173}$ Two intellectuals who became identified with this littoral culture, albeit in different ways, were the journalist, Wang T'ao (1828-1897) and the comprador who became a Western Affairs (yang-wu) "expert", Cheng Kuanying (1841-1920). ${ }^{174}$ Although both men came from coastal areas, their careers represented some very different orientations that traditionally educated intellectuals, who became "experts" in "Western Affairs", could follow in the last decades of nineteenth-century China. Wang T'ao pioneered the career of the émigré intellectual who sought to influence the intellectual climate from the safety of the treaty ports, and Cheng Kuan-ying represented a new, nontraditional, intellectual attitude, which was based on actual experience in treaty port affairs.

Wang T'ao's experiences present the classic case of the what Paul Cohen has called the "littoral reformer", lacking both effective sociopolitical

${ }^{172}$ Ch'ên, China and the West , p. 123. Chinese enterprises that were established to deal with the maritime commerce included not only those that dealt with foreign companies but also with Chinese trade between the treaty ports, between the ports and the interior, and between the mainland and overseas Chinese communities in Southeast Asia and the Pacific rim. See Cohen, "The New Coastal Reformers," p. 256. There might also have been the possibility of a foreign service career, if the young man was able to enter one of the Foreign Languages Institute classes for further language study.

${ }^{173}$ In 1872, in responding to a call for the dismantling of the naval programs at Foochow and Shanghai, Li Hung-chang wrote a memorial in which he used a phrase that would come to be applied to this era of Chinese history. Li defended the need for these relatively new programs by noting that China was now encountering "the greatest change of situation (pien-chü) in three thousand years." This pien-chü could clearly be seen in the intellectual vitality of the treaty-port cities, two of which were Foochow and Shanghai. See Kwang-Ching Liu, "Li Hung-chang in Chihli: The Emergence of a Policy, 1870-1875," In Feuerwerker et al., Approaches to Modern Chinese History, p. 85.

174 Because of his native province, Fukien, his overseas study in England, and his subsequent career in various coastal ports, Yen Fu could be considered a third type of coastal intellectual. Although he began his official activities during this era, Yen Fu's influence more properly belongs to the post-1895 educational reform efforts, and he will be discussed in that segment. 
power and sociocultural status. ${ }^{175}$ Born in Soochow, Wang had been classically educated by his father, who was a private tutor, and had passed the first rung of the examination ladder, the prefectural level, by the age of seventeen. His subsequent attempt to pass the provincial (chü-jen) examination met with failure in 1846, and he might have repeated the effort when the provincial examinations were offered next offered, in 1849, if it had not been for the death of his father that year. Pressed by the need to support his family, Wang T'ao took a step that reflected the new opportunities in the treaty ports. He accepted a translating position at the Shanghai London Missionary Society (Mo-hai shukuan) Press that year. This decision could be considered a turning point in his life, for Wang T'ao spent the remainder of his life in either Shanghai or Hong Kong, areas beyond the intellectual and cultural pale of China. ${ }^{176}$ During the twelve years that he spent in Shanghai, Wang was able to work with some of most effective missionary proponents of Western scientific learning, men such as Alexander Wylie, who was working with Li Shan-lan on translations of Euclid and Sir Isaac Newton. ${ }^{177}$ As with so many other young men of his era, Wang's career was affected by the political situation of China. In Wang's case, the specific political situation was the "interior disorder" of the Taiping rebellion and his perceived collaboration with the rebels, which forever closed the door to any

${ }^{175}$ Cohen, "The New Coastal Reformers," p. 259. In his 1861 essay, "On the Adoption of Western Knowledge," Feng Kuei-fen had denounced just this type of so-called "expert"; see the previous discussion on pp. 20-21 (Chapter 1).

${ }^{176}$ Cohen discusses this aspect as the phenomenon of "collaboration" in the opinion of traditional Chinese elite intellectuals. "Collaboration" referred to the sense that coastal intellectuals had somehow abandoned their tradition by working with or for foreigners. Reformerelite intellectuals, such as Li Hung-chang, Chang Chih-tung, and Liu K'un-i, frequently employed men from the treaty ports on their staffs; see Cohen's "The New Coastal Reformers," p. 259-60. Grieder termed the coastal areas, where Chinese and foreigners interacted, "culturally ambiguous" environments; see his Intellectuals and the State in Modern China, p. 99.

${ }^{177}$ Grieder, Intellectuals and the State in Modern China, p. 99. Li Shan-lan became the first Chinese professor of mathematics at the Foreign Languages Institute, under W.A.P. Martin, in 1869 [See footnote 144]. 
future within the borders of his homeland. ${ }^{178}$ From 1862, Wang T'ao would become the Chinese intellectual who could only look into his country from the outside safety of the foreign enclaves in Hong Kong and Shanghai. Whatever introductions of Western knowledge that Wang made to the Chinese intellectual climate of his day were made through the written and not the spoken word.

The "changed situation" (pien chü) of his day made it possible for Wang T'ao to be a émigré who could still make his opinions known and to add to the intellectual development of his motherland through new forms of media. The émigré might have been prevented from re-entering his homeland, but the artificial "borders" of the treaty ports would prove ineffective barriers to the introduction of new ideas.

Wang's position was not new; for there had been political exiles from China at various times in her history, in particular during the mid-seventeenth century, when the Manchu forces overthrew the Ming dynasty. ${ }^{179}$ The situation that had changed by Wang Tao's time was the fact that the extraterritoriality of the treaty ports allowed Chinese émigrés a "safe area" in which to continue working within their own borders. Although denied a traditional bureaucratic position, Wang pioneered a new career for a traditionally-educated Chinese intellectual, that of journalist. In 1870, after a trip to England as assistant to the renowned Scottish translator of the Chinese Classics, James Legge, and a

\footnotetext{
${ }^{178}$ The Ch'ing government considered his 1860-61 journey to the Taiping-controlled area of Soochow and Nanking and subsequent letters to rebel leaders as evidence of his traitorous conduct. Although nominally a Christian, Wang Tao always protested that he was innocent of any collaborative association with or support of the quasi-Christian T'ai-p'ings; see Grieder, Intellectuals and the State in Modern China, pp. 99-100; and Cohen, "Wang T'ao's Perspective on a Changing World," in Feuerwerker et al., Approaches to Modern Chinese History, p. 135. Paul Cohen is the acknowledged Western biographer of Wang T'ao. In addition to the two works cited here, Dr. Cohen has also written Between Tradition and Modernity: Wang T'ao and Reform in Late Ch'ing China (Cambridge: Harvard University Press, 1962).

${ }^{179}$ Julia Ching has written an excellent short study, detailing some of the difficulties for one of these Ming émigrés; see her article, "Chu Shun-shui, 1600-1682, A Chinese Confucian Scholar in Tokugawa Japan," in Monumenta Nipponica, Vol. XXX: 2, pp. 177-191. Chu made valuable contributions to the development of Japanese Neo-Confucian thought through his position as tutor to the daimyo (lord) of the one of the cadet Tokugawa hans (domains) in Japan. If Chu had lived during the time when treaty ports offered a safe haven for Chinese intellectual émigrés, his contributions might have been to Ch'ing thought.
} 
subsequent tour of Europe, Wang established the Hsün-huan jih-pao ${ }^{180}$, a Hong Kong daily newspaper, covering current events and presenting the ideas of a man who could be considered one of the leading examples of the crosscultural influences found in the treaty ports. ${ }^{181}$ Written in clear, elegant Chinese (rather than the more stilted, scholarly wen-yen), the newspaper presented editorials on the country's current situation with a call for Chinese development of wealth and power (fu-ch'iang) through the promotion of both commercial strength (shang- $/$ ) and military strength (ping- $I$ ) at the same time. ${ }^{182}$ Wang's proposal equating the importance of commercial development to military modernization reflected the attitudes of a new strata of educated Chinese, the treaty port bourgeoisie. ${ }^{193}$ This was the new element in the intellectual environment of the treaty ports created by those who had gradually come to the opinion that Western knowledge was primary in the development of their

180 "Hsün-huan jih-pao" literally can be translated "Cyclical Daily News" or "Revolving Daily News". Either translation is awkward. Grieder noted this problem in a footnote to the title, and simply left it in romanization without translation. See his footnote in Intellectuals and the State in Modern China, p. 95. I have chosen to follow his example. An alternative could be "The Cycle of Daily News". The translation of "Natural Evolution Paper" is given in Chesneaux, et al., China From the Opium Wars to the 1911 Revolution, p. 237.

${ }^{181}$ Both Grieder and Cohen describe this attitude produced by the overlapping of the cultures in the treaty ports as "cosmopolitanism". See Grieder, Intellectuals and the State in Modern China, pp. 100-101; and Cohen, "The New Coastal Reformers," p. 257. This "cosmopolitanism" was an externally oriented Chinese world-view, which was a direct contrast to the internally oriented Chinese "world-view" associated with the cross-cultural interactions of the traditional tribute system.

${ }^{182}$ Grieder, Intellectuals and the State in Modern China, pp. 102-103. This was a contrast to the Self-Strengthening Movement's initial stress on the technological improvement of the military system as the primary method to make China strong. Although Li Hung-chang later added commercial development in the kuan-tu shang-pan enterprises, such as the Lun-ch'uan chaoshang chü in 1872-73, this aspect of the modernization program never attained parity with the importance of military strengthening in the Self-Strengthening Movement. Although the SelfStrengthening efforts included educational reforms, as noted, the successes were principally connected with the establishment of separate military technical institutes. In Biggerstaff's list of the seven types of modern training institutions established during the Self-Strengthening era, four were directly related to the military, and one (telegraphy) had military applications [Footnote 136]. For the discussion of the kuan-tu shang-pan enterprises under Li Hung-chang, see pp. 4344 [Chapter 1].

${ }^{183}$ Chesneaux, et al., China From the Opium War to the 1911 Revolution, p. 237; and Cohen, "The New Coastal Reformers," p. 256. 
country and necessary to the preservation of their cultural tradition. These "coastal" intellectuals had begun to develop a sense of "country", an incipient "national identity", through their continuing interactions with the Western nations. ${ }^{184}$

In the Hsün-huan jih-pao, Wang T'ao might have been reflecting the attitudes of his readership, but he also wrote articles based on his own extensive knowledge of the outside world. From his time in England and his tour of France, Wang had developed decided opinions on those nations. Although he did not write a great deal on England, his observances were penetrating. In the early 1880s, Wang wrote praise of England:

"The real strength of England lies in the fact that there is a sympathetic understanding between the governing and the governed....a close relationship between the ruler and the people."185

On the other hand, Wang T'ao wrote a great deal about France, including a national history and a widely-read account of the 1870-71 Franco-Prussian War ${ }^{186}$, and his assessment of that country was much harsher:

"France is truly a war-loving country.... Her kings and nobles, through the ages, have all striven for glory and victory....They attack abroad and extend their territories at home."1187

After spending some time in Japan, Wang viewed the increasing ambitions of

${ }^{184}$ Cohen cites two situations in the treaty ports that stimulated this nascent sense of nationalism. The first was the supercilious attitude of the Westerners toward their Chinese neighbors, and the second was the Chinese conceptualization of a successful coordinated economic confrontation with the West. See his "The New Coastal Reformers", pp. 257-58. The Chinese reaction to the first could be termed a sense of national identity, and the second concept could be defined as economic nationalism. Grieder terms Wang T'ao's attitude toward the "commercial Self-Strengthening" of Li Hung-chang as one of "economic nationalism". See Intellectuals and the State in Modern China, p. 103.

${ }^{185}$ Quoted in Grieder, Intellectuals and the State in Modern China, p. 104.

${ }^{186}$ This was titled P'u-Fa chan-chi(An Account of the Franco-Prussian War) and was published in 1873 and reprinted in Japan in 1878 and 1887 . It was well received by Chinese intellectuals, such as Li Hung-chang and Liang Ch'i-ch'ao. Cohen, "Wang T'ao's Perspective on a Changing World," pp. 136-37, 148. Cohen also lists Tseng Kuo-fan as one who praised it, but Tseng had died in 1872. Either the date of the initial publication might have been incorrect or the reference might be to Tseng's son, Tseng Chi-tse, who was often called Marquis Tseng.

${ }^{187}$ Quoted in Grieder, Intellectuals and the State in Modern China, p. 104. 
that country in Pacific Asia in much the same way, suggesting that Japan may have caught the "French disease" and commenting on the current situation:

"The scholars of Japan have eyes only for their country's imitation of the West.... [They] are convinced that they can become strong. They don't realize that, in fact, their strength is on the surface only, and that they are weak within." ${ }^{188}$ Although these three assessments represented the views of one man who had actually studied the foreigners in their own countries, they also indicated the new awareness of external events and foreign attitudes that was becoming a part of the intellectual climate of the treaty ports. ${ }^{189}$

In view of the fact that coastal ports existed in a tangential relationship to intellectual development in the interior, Wang T'ao's contributions to the development of Chinese educational thought through his journalism might have remained an interesting side trip to this discussion. However, Wang T'ao also made direct contributions to the introduction of Western knowledge through his life-long translation work with Protestant missionaries. The translations that had a direct bearing on this subject were: the 1853 translation, K'o-chih hsi-hsüeh t'i-yao (The essentials of science and western learning); an 1858 translation of K'o-chih hsin-hsüeh t'i-yao (The essentials of science and the new learning); and a six-volume compilation, Hsi-hsüeh chi-ts'un liu-chung (Six works on western learning), issued in the years $1889-1890 .^{190}$ The very fact that these works were considered worth translating should be an indication of the growing

${ }^{188}$ Quoted in Grieder, Intellectuals and the State in Modern China, p. 102.

${ }^{189}$ Refer to the previous discussion on the "cosmopolitanism" of treaty port intellectuals. See also the discussion of China and the world order in Grieder, Intellectuals and the State in Modern China, pp. 100-101; and the linking of European events with changes in the Chinese situation in Wang T'ao's thought in Cohen, "Wang T'ao's Perspective on a Changing World," pp. 148-49.

${ }^{190}$ The first two were collaborative efforts with Joseph Edkins and the last one represented the work of Wang T'ao and Alexander Wylie. Most likely, all three works were published in Shanghai. Wang T'ao had worked in that city prior to his proscription by Ch'ing authorities in 1861 . After spending the years 1870 to 1883 in Hong Kong, Wang returned to Shanghai in 1884, where he had accepted a position with John Fryer's Shanghai Polytechnic Institute and Reading Room. The titles are listed in Cohen, "Wang T'ao's Perspective on a Changing World," p. 136; see also Grieder, Intellectuals and the State in Modern China, p. 104. In addition, Wang T'ao also wrote articles on Western learning and scientific subjects. It would be interesting to discover if any of these essays had been published in Fryer's Shanghai periodical, K'o-chih hui-pen. See the discussion of Fryer's activities p. 33-34 [Chapter 1]. 
interest in Western learning among Chinese readers.

Wang T'ao was not the only "coastal" intellectual who was interested in spreading Western learning to the Chinese interior. Cheng Kuan-ying represented a different type of treaty port "Western-affairs expert" and one that was completely outside of the Chinese scholarly tradition. Although he had a traditional education, Cheng took an untraditional route to status. After his failure in the examination system, he first gained economic status as a Shanghai comprador and then gained intellectual status as a treaty port scholar. Economically, he was tied to the Ch'ing establishment reformers through his association with Li Hung-chang's "official supervision/merchant management" enterprises, such as the K'ai-p'ing coal mines and the Imperial Telegraph Administration. ${ }^{191}$ Intellectually, Cheng influenced educated elite Chinese through collections of essays, published from 1862 through the 1890s. ${ }^{192}$

In a special essay, written in response to the events of $1885^{193}$, Cheng Kuan-ying eloquently defended the need for Western learning:

"Those who have a reputation as purists these days, and who regard themselves as upright men, haughtily refuse to discuss foreign matters, and condemn those who advocate seeking Western learning as offenders against the sacred principles of the tradition and as a disgrace to the scholarly class.... Of

${ }^{191}$ See discussion of Li Hung-chang's official supervision/merchant management companies on pp. 42-3 [Chapter 1]. For Cheng Kuan-ying's involvement, see Grieder, Intellectuals and the State in Modern China, p. 105; and Chesneaux et al., China From the Opium Wars to the 1911 Revolution, pp. 226-27. For a translation of Cheng's criticism of the official supervision/merchant management companies, see Teng and Fairbank, China's Response To the West, pp.113-115

192 In 1862, a collection of Cheng's essays was published as Chiu-shih chieh-yao (What is to be done?). In 1872, the collection was revised, enlarged, and republished as I-yen (Easy advice). By far the most influential work of Cheng Kuan-ying was the Sheng-shih wei-yen (Words of warning to a prosperous age), issued in several printings, during the 1890s. See Grieder, Intellectuals and the State in Modern China, p. 105. In 1938, when recounting his life story for Edgar Snow, Mao Tse-tung would mention how important reading Cheng's Sheng-shih wei-yen was to the development of his skeptical attitude toward Chinese traditions and to his decision to pursue further education beyond what his father had thought was necessary for a thirteen-yearold peasant youth in 1906. See Edgar Snow, Red Star Over China (New York: Bantam Books, 1978 revised and enlarged edition), pp.118-19.

${ }^{193}$ See the discussion of the Sino-French war and the Japanese encroachments in Korea [Chapter 1, page 42]. 
what use in such times and to the urgent concerns of men is the conventional fidelity of conventional people to conventional principles? Foreign matters nowadays are timely matters. If we would seek a cure to the disease of the age we must prescribe for the symptoms. If your prince or your father lay critically ill would you, as a loyal minister or a filial son, do whatever you could to seek out and master the arts of medicine, or would you, neither seeking nor studying it, disparage medical knowledge as unreliable, and swearing an oath to be buried with the body, sit by to watch death come? May we not then get on with it, wasting no more words in argument as to whether we should or should not discuss Western learning?"'194

These were strong words indeed and they would not fall on deaf ears. However, much like the new attitudes expressed by Wang T'ao in his Hong Kong newspaper, Cheng Kuan-ying's bitter question, "May we not then get on with it...?", would have to wait for a positive response from the next transitional generation. ${ }^{195}$

\section{EDUCATIONAL REFORM WITHIN TRADITIONAL STRUCTURES: A CONTINUATION OF THE SELF-STRENGTHENING PATTERN}

As noted, the T'ung-chih Restoration political reform effort was effectively over by the end of the young emperor's reign in 1874. These efforts had sought to reestablish a Confucian sense of order to the state, and on the surface, the relative peace within the Middle Kingdom signaled a success. ${ }^{196}$ Although $\mathrm{Li}$ Hung-chang had memorialized the throne in this year on the danger of merely

\footnotetext{
${ }^{194}$ Quoted excerpt from Cheng's Hsi hsüeh (Western learning) in Grieder, Intellectuals and the State in Modern China, pp.105-106. On the importance of these years to the educational reform effort, see the previous discussion of Chang Chih-tung on pp. 42-3 [Chapter 1]. The underlining is mine.

195 On Wang T'ao's lack of political influence in his own time, see Kwang-Ching Liu's remarks during the general discussion in Cohen and Schrecker, Reform in Nineteenth-Century China, $p$. 181. On Cheng Kuan-ying's influence on later reformers, see Chesneaux et al., China From the Opium Wars to the 1911 Revolution, pp. 282-83; and Wilbur, Sun Yat-sen. Frustrated Patriot, p. 16.

${ }^{196}$ See Jerome Ch'ên's discussion of the restoration policy in his "Historical Background," in Jack Gray [ed], Modern China's Search for a Political Form (London: Oxford University Press, 1969), p. 4.
} 
maintaining the status quo and called for both "the change (pien-fa) of institutions and the proper use of personnel (yung-jen)," little effort was made to alter the system. ${ }^{197}$

Of course, Li was a significant and somewhat exceptional figure in the last quarter of the nineteenth century in China. ${ }^{198}$ His calls for reform could have been considered merely the actions of an atypical individual Chinese bureaucrat. However, the call for reform within the system that had been raised by coastal reformers was also becoming a significant message from members of the traditional scholarly elite. One of the most articulate of these scholarbureaucrats was Hsüeh Fu-ch'eng (1838-1894), who served as secretary to both Tseng Kuo-fan (from 1865 to 1872) and Li Hung-chang (from 1875 to 1884). It was during his service with $\mathrm{Li}$ that Hsüeh compiled a volume of his essays, entitled Ch'ou-yang ch'u-i ${ }^{199}$, from which the following excerpts are taken.

In his essay, Pien-fa (On reform), Hsüeh presented a view of the historical process that included an argument for the necessity to reform the strength of Chinese tradition with the need to adjust to a rapidly changing world. Hsüeh's argued for systemic change:

"In my opinion there have been no more that ten thousand years from the beginnings of humankind to the present day. How can this be shown? By the rapidity of changes in the world. It is the Way of Heaven that there is a minor change every several hundred years and a major change every several thousand

${ }^{197}$ Kwang-Ching Liu, "Li Hung-chang in Chihli: The Emergence of a Policy, 1879-1875," p. 93-100.

${ }^{198}$ Immanuel Hsü writes that Li was "unrivaled" for the leadership of the Self-Strengthening Movement in the years 1872-1885 and was responsible for "over 90 per cent of the modern projects" inaugurated in those years. See his The Rise of Modern China, (New York: Oxford University Press, 1970), pp. 344-45.

199 The standard translation given for "Ch'ou-yang ch'u- $l$ " is "Rough discussion of the management of foreign affairs." See Teng and Fairbank, China's Response to the West, p. 140, and Chesneaux, et al., China From the Opium Wars to the 1911 Revolution, p. 245. Since the topics of the fourteen essays in this collection include such subjects as the "handling" of Russia and Japan, the "securing of intelligence about the enemy," and the "asserting" of China's sovereignty, I felt that the translation of "Ch'ou" may not have been exact. However, without being able to find the title in the Chinese characters, I decided to leave it untranslated. I believe that "Ch'ou-yang ch'u-r" might be translated as: "A preliminary discussion of foreign rivals". 
years....With the accumulation of the sages industrious enterprises, All-underHeaven changed from primitive to civilized....By the time [of] Ch'in Shihhuang...two thousand years had passed since Yao and Shun. All-under-Heaven changed from the feudal system to the imperial system....[N]ow, because of their knowledge of machinery and mathematics, the nations of the West thrive beyond the seas, reaching the farthest limits of the earth as easily as strolling in their own yards, harnessing the wind and thunder as easily as they move their own fingers and arms. Over the $90,000 \mathrm{li}$ of the globe, there is no place that they do not trade or send envoys... And now once again it has been two thousand years since the Ch'in and the Han. All-under-Heaven has changed from China and the barbarians being separated to China and the barbarians having contacts and connections....

"Today the world is rapidly changing. In my opinion, with regard to the immutable Way, the present should be changed so as to restore the past, and with regard to the the changeable laws, the past should be changed to bring it up to date....The nations of the West rely on intelligence and energy to compete with one another. So that our China can stand up to them, we should make plans for commerce and mining; unless we change, they will be rich and we poor. Skills in crafts and manufacturing should be perfected; unless we change, they will be skillful and we clumsy. Steamships, trains, and the telegraph should be promoted; unless we change they will be swift and we slow. The advantages and faults of treaties, the qualities of envoys, and changes in military systems and organizations should be studied; unless we change, they will cooperate with each other and we shall be isolated, they will be strong and we will be frail."200

In this brief analysis, Hsüeh was connecting the historical adaptations of Chinese institutions to the present "change of situation" [pien chü]. ${ }^{201}$ By noting the historicity of change ("every several thousand years"), he was arguing that the reform of traditional institutions had been a natural response to historical "change of situation".

In addition, Hsüeh's presentation of this historical pattern of change clearly represented a different attitude toward Chinese history than had previously been evident in traditional scholarship. By arguing that social, political, and economic institutions had been altered in response to the circumstances of the time, Hsüeh was presenting a linear view of historical

${ }^{200}$ Excerpted from the translation in Gentzler, Changing China, pp. 76-79.

${ }^{201}$ See the discussion of Li Hung-chang's use of this term in his 1872 memorial [footnote173]. 
change, which was closer to the Western concept of historical "progress" than to the Confucian world view of cyclical fluctuation. ${ }^{202}$

Therefore, his implied conclusion was obvious. Having shown that major change occurred periodically and that it had been two thousand years since the last major change ("the Ch'in and the Han"), Hsüeh concluded that it was time for China to change. After making these points, he then presented two opposite views in the present intellectual debate over the use of Western learning :

"Some may say, 'If our great country imitates the Westerners, is this not using barbarian ways to change China?' This is not so. In clothing, language, and customs, Chinese and foreigners differ, but in making use of the forces of nature and in benefiting the people, Chinese and foreigners are alike. The Westerners happen to be the first to catch the winds of change. But are the Westerners to monopolize the secrets nature discloses? How do we know that within several decades or a century China will not overtake them?...

"Some may also say, 'In making reforms [pien fa], we should strive to surpass the Westerners, not to pursue them. Today, Western methods excel; if we imitate them slavishly, how will we ever surpass them?' This too is not so. In order to surpass others, we must first have a thorough knowledge of their methods before we can change, and only after changing can we surpass them. We cannot surpass them by sitting upright and immobile. If now, seeing that others are ahead of us, we scornfully say that we will not condescend to follow them, we shall not be able to budge half a step. Moreover, they brought together the talents and energies of millions of people and expended vast sums of money over a long period of time before acquiring this knowledge. Now we want to surpass them in a single day. Can this really be done?... If we compare the talent and intelligence of Chinese and Westerners, can we find any reason why we should not be able to

${ }^{202}$ In his opening remarks at the workshop on nineteenth century reform in China held in July, 1975, at the Harvard University East Asian Center, John K. Fairbank noted: "The Confucian world view included fluctuation and the interaction of yin and yang, but did not include the concept of linear change. Reform is therefore seen as a revival of the past." See the summary of his opening remarks in Cohen and Schrecker, Reform in Nineteenth-Century China, p. 3. It would seem that, in this 1879 essay, Hsüeh Fu-cheng might have been introducing an historical theory which could have been influenced by Western ideas. 
surpass them? The answer lies in urging ourselves on."203

In presenting responses to two possible arguments regarding foreign learning, Hsüeh Fu-cheng's essay shows how the Chinese intellectual climate had changed in the years since the 1867 debate between Wo-jen and the Tsungli Yamen over the inclusion of astronomy and mathematics in the Foreign Languages Institute curriculum. ${ }^{204}$ At that time, there had only been two sides to the debate. In this 1879 essay, Hsüeh presented three positions on reform: 1) the conservative insistence on preservation of the tradition ("using barbarian ways to change China"); 2) his own suggested schedule for the adaptation of Western learning ("within several decades or a century"); and 3) the insistence that immediate change was possible ("to surpass them in a single day").

Even though significant changes had not yet occurred in the outward structure of the educational system, Hsüeh's 1879 essay demonstrated that an important change had developed in the underlying intellectual climate for reform. That change was indicated by the third position. Some advocates of reforms were no longer arguing the need for changes but were developing impatience with the lack of those changes. The growth of this impatience would become a characteristic of the intellectual climate for reform in the final two decades of the Ch'ing dynasty.

By the 1880s, some gains had been made through the establishment of permanent Chinese diplomatic missions in foreign countries, the publication of

\footnotetext{
${ }^{203}$ Excerpted from the translation in Gentzler, Changing China, pp. 76-79. A slightly different translation of parts of the essay can be found in Teng and Fairbank, China's Response to the West, pp. 142-43. There are also three excerpts from Hsüeh's diaries, recorded during his diplomatic assignments in Europe in the years 1890 to 1894, among the translations in this volume. Grieder has also cited a portion of the Pien-fa essay to point out the anachronism in the Self-Strengthening concept. See his Intellectuals and the State in Modern China, pp. 74-5. I believe that the section of the essay dealing with Hsüeh's responses to the other two positions might argue for a more flexible assessment of the Self-Strengthening concept.

${ }^{204}$ See the discussion on this debate on pp. 26-7 [Chapter 1]. This conservative argument has been traced back to Mencius: "I have heard of men using the doctrines of our great land to change barbarians, but I have never yet heard of any being changed by barbarians." Legge's translation of The Works of Mencius, Book III, Part I, Chapter IV: 12, p. 253. Mencius wrote this well over a century before the last period of major change that Hsüeh had identified (the time of Ch'in and Han).
} 
Chinese-language newspapers which covered international events ${ }^{205}$, the development of a "cosmopolitan attitude" among the new Chinese treaty port intellectuals, and the birth of a "reform consciousness" among the traditional Chinese scholarly elite. However, even with the addition of Chang Chih-tung's voice to the Self-Strengthening efforts during this decade, the pattern for educational reform remained that of randomly established institutions, which frequently prospered or languished according to the interests of individual governors during their terms of office, within a relatively unchanged tradition.

One such educational institution was opened outside of Canton at Whampoa in 1882 with fifty students, under the aegis of the Liang-kwang Governor-General, Chang Shu-sheng, who named it the College of Solid Learning (Shih-hsüeh kuan). When Chang Chih-tung arrived in Canton in 1884, he renamed the institution the College of Extensive Learning (Po-hsüeh kuan). However, the curriculum, which included mathematics, English language, and Chinese literature, remained the same until 1887, when Chang added military and naval sciences to the curriculum and renamed the school the Kwangtung Naval and Military Officers' School (Shui-lu-shih hsüeh-t'ang). ${ }^{206}$ The student body was to be increased to a maximum of 140 students, many of whom would come from the Foochow and Tientsin institutions, which would supply most of the faculty as well. The expanded training programs included English language study for naval students and German language study for military cadets. Even though Chang Chih-tung had insisted that the students study the Four books and the Five Classics daily (in order "to strengthen the root" of their knowledge) and the school began to graduate some promising officer-trainees, after his period of office expired and Chang had been

\footnotetext{
${ }^{205}$ Chinese language publications on state affairs had existed for centuries in China. Official information (Imperial edicts, appointments, etc.) was printed in what was known as the Ching-pao (Capital news or Peking Gazette, in the West). However, the Ching-pao was not a single public organ but a combination of several private publications; this practice was also repeated in most of the provincial capitals.

${ }^{206}$ It should be noted that in 1884-85, Chang had been very involved with the Sino-French War over Annam and this event undoubtedly influenced his decision to alter the school's curriculum in 1887. Refer to the previous discussion of Chang Chih-tung's "conversion" to SelfStrengthening reform in Chapter 1, pp. 42-3.
} 
transferred to Hu-kwang in 1889, the institution languished under the more conservative new governor-general. ${ }^{207}$

This was just one example of the identification of specific "training" facilities with specific reformer-bureaucrats. Li Hung-chang's ability to insure both the establishment and the maintenance of his many projects in Chihli due to his long tenure in Tientsin was the exception to the practice of frequent transfers for high-ranking provincial officials; the fate of the Kwangtung Naval and Military Officer's School and the uneven development of the Foochow Naval Shipyard School were much more typical of the common rule.

During these early provincial posts, Chang began to formulate his ideas that would lead to the new educational combination he would eventually set down in his 1898 Exhortation to learning (Ch'üan-hsüeh p'ien). From his earliest positions as Director of Education in the provinces of Hupeh and Szechwan, Chang had developed his critical interest in the formulation of a Chinese educational system that would culminate in his 1898 publication and forever identify him with the reform of schools in late Ch'ing China. Before he became convinced of the need for Self-Strengthening at the time of the SinoFrench War, Chang had displayed his interest in the traditional Chinese system through his establishment or reorganization of traditional Confucian academies (shu-yüan). As has been noted, these academies were usually private institutions of learning, although they occasionally had connections to the local government structures through their funding, as the following description indicates:

${ }^{207}$ In coupling specific language programs with specific training, Chang was following Li Hungchang's method. Refer to the discussions on Li's 1876-77 program sending Foochow naval students to England and his 1885 establishment of the Tientsin Military Preparation Academy [Chapter 1, pp. 32 and 41, respectively]. For a full discussion of the changes in this one Canton/Whampoa educational facility, see Ayers, Chang Chih-tung and Educational Reform, pp. 108-113. Ayers notes that the school eventually shut down for a time but was reorganized to become the Whampoa Naval Academy of the early Republic. I believe that this institution was also known as the Whampoa Military Academy, which later became known as one of the joint Kuomintang/CCP United Front efforts. The Academy's military commandant was Chiang K'ai-shek and Chou En-lai served as one of his assistants in the early 1920s. Lin Piao (1908-1971), who became Mao's designated heir at the beginning of the Cultural Revolution in 1966, was a graduate of the fourth class at Whampoa in 1925. See Lin's autobiographical statement in Helen Foster Snow (Nym Wales), The Chinese Communists: Sketches and Autobiographies of the Old Guard (Westport, Conn.: Greenwood Publishing Company, 1972), p. 164. 
"A Shu-yüan consisted usually of an endowment of land, a library, a well-known scholar as director, and a number of students, who were given a small allowance to cover at least part of their expenses. The expenses of the academy were defrayed from the proceeds of the land endowment and, in some cases, a subsidy was granted by the local authorities. No lectures were given [regularly] in the academy: the function of the professor was only to advise the students as to their reading and criticize the results of their researches. Occasionally the professor or an outside scholar would lecture on some selected topic, but, on the whole, the Shu-yũan was a place of self-study, and a center of research under expert guidance." 208

Chang's interest in these traditional academies resulted in the founding of one institution in Hupeh, the Chiang-nan shu-yüan, in 1869 and one in Szechwan, the Tsun-ching shu-yüan, in 1874-75. In his subsequent three assignments, Chang co-founded the Ling-te shu-yüan in Shansi in 1882, the Kuang-ya shuyüan in Kwangtung in 1887, and the Liang-hu shu-yüan in Wuchang in 1890 to serve Hunan and Hupeh. ${ }^{209}$ The fact that Chang continued to establish traditional academies even after his decision to support Self-Strengthening efforts represented his total commitment to the continuation of the Chinese intellectual heritage through the educational process.

${ }^{208}$ From T'ang Leang-li, China in Revolt (London, 1927), cited in Ayers, Chang Chih-tung and Educational Reform, p. 16. The method of instruction in the academies (a professor supervising readings and critiquing research) sounds somewhat similar to Leopold von Ranke's innovative use of the "seminar" in training young historians in nineteenth-century Germany; see Ernst Breisach, Historiography: Ancient. Medieval, \& Modern (Chicago: The University of Chicago Press, 1983), p. 233.

${ }^{209}$ See Ayers descriptions of these academies, their foundings, and their subsequent development in Ayers, Chang Chih-tung and Educational Reform, pp. 54-62. The Liang-hu Academy also admitted a number of the students from a nontraditional group, the sons of $\mathrm{Hu}$ kwang tea merchants. 
In addition to his continued promotion of traditional schooling ${ }^{210}$, Chang was reformulating his attitude toward Western learning. In these years, he became more eclectic in his approach to learning, writing that the purpose of Chinese education must be to "blend the Chinese and Western with thorough understanding and discrimination, in the hope that education will create talent and prepare responsible officials for the Empire." As the international political climate became more difficult for China in the years after the Sino-French War, Chang would write: "If we wish to control the changing times, we must establish schools."

Although he had established Western training facilities as well as the traditional academies in his two previous appointments, Chang Chih-tung became known for the institutions that he organized in the $\mathrm{Hu}-\mathrm{kwang}$ area, ${ }^{212}$ as Li Hung-chang had become identified with his projects in the Chihli area. It was also during these years that Chang would establish himself as a rival to $\mathrm{Li}$ Hung-chang in Tientsin and to Liu K'un-i in Nanking in the competition for qualified and able young Chinese Western-affairs experts that marked the years

${ }^{210}$ In 1870, Chang had compiled a bibliography of suggested readings for the promotion of education that was widely circulated through official channels. This bibliography did not include a single book of Western learning. See Hao Chang, "The Intellectual Context of Reform," in Cohen and Schrecker, Reform in Nineteenth-Century China, p. 148. However, one interesting aspect of Chang's promotion of traditional education was that he did not include a course on the "eightlegged essay" in the curricula of the academies that he set up during this time. When questioned about the omission in 1875, Chang replied: "There is no need!" Quoted in Ayers, Chang Chihtung and Educational Reform, pp.56-57. This was an early indication that Chang had not forgotten his early criticism of the examination system in his 1863 palace essay and was not as conservative in his educational reform outlook as he was in his political views at this time. See the previous discussion, pages 36-7 [Chapter 1].

${ }^{211}$ Both quotations are from Ayers, Chang Chih-tung and Educational Reform, p. 105.

${ }^{212}$ As early as 1882 , Chang had discussed modernization suggestions with Timothy Richard (1845-1919), a Welsh missionary who would become the secretary for the S.D.K. and an influential advisor to the reformers, and had organized the Yang-wu chü (Office of Foreign Affairs) in 1884, while he had been governor of Shansi province. As noted, he enlarged the Canton/Whampoa school during his term as governor-general of the Liang-kwang. The Hu-kwang administrative area covered the provinces of Hunan and Hupeh and contained the vital Yangtze treaty port area of the Wuhan cities (Wuchang, Hanyang, and Hankow). Chang Chih-tung served as Hu-kwang governor-general from 1889-94, 1895-1902, and 1904-1907. See footnote 100 [Chapter 1] and the chart of "Selected Governors-General in the Late Ch'ing Period," in Fairbank, et al., East Asia: The Modern Transformation, p. 353. 
1885-1898. ${ }^{213}$ Even though the addition of Chang and Liu had enlarged the scope of the elite commitment to Self-Strengthening reform by 1890 , their efforts continued to be within the individual success pattern established by Li Hungchang.

In examining this pattern of individual success against a backdrop of "general" or "national" failure, two factors influenced this pattern. The first was related to the absence of a coordinated "national" commitment to modernization projects, which had the effect of attracting Self-Strengthening proponents among the lower bureaucratic ranks to service under these top officials who had definite, individual agendas and projects. This attraction of men of like mind to specific individuals can be related to the tradition of the "superior man" in Confucian society, which promoted vertical hierarchical relationships. ${ }^{214}$ Therefore, elite officials such as Li Hung-chang could attain the services of a scholar-bureaucrat like Hsüeh Fu-cheng for his staff or of a compradorspecialist like Cheng Kuan-ying for his unofficial private secretariat (mu-fu) during these years. Conversely, an adherent of the "Pure Flow Party" (ch'ing-liu tang), which opposed $\mathrm{Li}$, such as Chang Chih-tung in his early bureaucratic positions (1860s-1870s), would not seek employment in the service of an ideological or political opponent.

The second factor was a combination of the lack of a strong voice for reform in the center (the court) and the attenuation of central control in the waning decades of the dynasty. With the absence of an intellectual climate for reform at the top, modernization efforts increasingly became concentrated at the provincial levels, ${ }^{215}$ where they could be controlled by the more direct

\footnotetext{
${ }^{213}$ Ayers, Chang Chih-tung and Educational Reform in China, pp. 102-103; and Immanuel Hsü, The Rise of Modern China, (New York: Oxford University Press, 1970), pp. 346-37.

${ }^{214}$ See the examples of the ideal Confucian relationship between master and student in the Analects: Book I: Chapters II, IV, VIII, XIII, and XIV, in Legge, Confucius: Confucian Analects. The Great Learning \& The Doctrine of the Mean, pp.137-144.

${ }^{215}$ See the discussion on the "persistent weakness at the center" in Cohen, "The Post-Mao Reforms in Historical Perspective," in The Journal of Asian Studies, pp. 520-21. Daniel Bays has proposed that these concentrations of power in the hands of regional governors-general were actually extensions of the central authority into new, more risky, modernization efforts, such as "educational, military, and economic activities", that could be better controlled on a local level. See his China Enters the Twentieth Century (Ann Arbor: The University of Michigan Press, 1978), p. 4.
} 
relationships between these individual bureaucrats and local elite interests. ${ }^{216}$ Therefore, when reviewing the introduction of new learning or training in the 1880 s and 1890s, one can see several "centers" of activity: large "pockets" of modernization, such as the Chihli/Northern Ports area and the Wuhan/Hukwang region; smaller growth areas, such as Nanking; the province and port with the longest association with the West, Kwangtung/Canton; and the Westernizing "littoral", such as Shanghai and the British/Chinese city of Hong Kong.

At the same time that this phenomenon of individualized projects became the focus of a few reformers among the top echelon, changes were also occurring among the rank and file bureaucrats. One of these changes was due to the disruption of the social structure during the "internal disorder", when the Taipings had devastated the heartland of China. The years of rebellion had disrupted the traditional examination system in those ares and had resulted in an imbalance in the bureaucratic structure, allowing a selected few, such as $\mathrm{Li}$ Hung-chang, to advance much more rapidly and acquire much more power than through the normal distribution of positions in peaceful times. In addition, the examination quotas had been raised to fill lower official ranks in order to redress the imbalance, creating greater competition for the same number of positions. This left a number of dissatisfied young intellectuals, who would either seek nontraditional positions, such as Wang T'ao and Cheng Kuan-ying had, or would become associated with criticism of those in power. This later group, which has been identified as a "ch'ing-r" (incorruptible discussion) movement by John Schrecker, remained within the traditional bureaucracy but effectively outside of the existing power structure. ${ }^{217}$

As this "movement" derived from political opposition to the existing power holders, its relationship to educational reform efforts was largely tangential.

\footnotetext{
${ }^{216}$ See the summary by James Polachek, "Reform At the Local and Provincial Level," in Cohen and Schrecker, Reform in Nineteenth-Century China, pp. 211-12.

${ }^{217}$ See John E. Schrecker, "The Reform Movement of 1898 and the Meiji Restoration as Ch'ing-i Movements," in Iriye, The Chinese and the Japanese, pp. 97-98. Schrecker made a point on the difficulty of translating this term into English and suggested that "Movement for renovation" would be a "reasonable" translation. Ch'ing-i literally means "pure talk" or "clear expression".
} 
However, as in the earlier period, when Self-Strengthening proponents had attempted to alter the examination system, politics continued to influence the outcome of educational reforms in the 1880 s and the 1890s. Since one of the policies of the top echelon officials in late Ch'ing China was the promotion of specialized institutions for the study of Western learning, ch'ing-i bureaucrats initially opposed this practice. Instead of promoting training to produce Western Affairs experts, these traditionally educated literati called for the improvement of the existing educational structure, in particular, the academies. ${ }^{218}$ Therefore, although opposed to Western learning in the 1870s, the ch'ing-i movement was not unaware of the need to change the existing educational system. In those years, their approach was one of renovation, not innovation. ${ }^{219}$

However, since this was a political and intellectual movement, the ch'ing-i was just as subject to influences arising from the "changed situation" of the day as the Self-Strengthening Movement had been. Chang Chih-tung, who had been one of the leading proponents of ch'ing-ithrough his connection to the Pure Flow Party, had reacted to just such a changed political scene, when he became convinced of the need for Self-Strengthening in the aftermath of the Sino-French War of 1884-85. ${ }^{220}$ In the next decade, another member of the "Pure Flow Party", Chang Chien, would react to another Chinese defeat (the Sino-Japanese War) by dropping national political activity in favor of educational reform at the local level. ${ }^{221}$

A third aspect of the ch'ing-iphilosophy that would eventually connect it to later educational reform attempts developed from two changes in the movement's opposition to the existing governmental power structure. In addition

${ }^{218}$ See John E. Schrecker, "The Reform Movement of 1898 and the Ch'ing-i. Reform as Opposition," in Cohen and Schrecker, Reform in Nineteenth-Century China, pp. 290-91.

${ }^{219}$ This concern for traditional education clearly ties the ch'ing-i proponents to Wo-jen's opposition and Chang Chih-tung's educational efforts in the 1870s and 1880s--the establishment of academies.

${ }^{220}$ Refer to the previous discussion of Chang Chih-tung's "conversion" on pages 42-3 [Chapter 1].

${ }^{221}$ See Bastid, Educational Reform in Early Twentieth-Century China, pp. 20-21, 27-28; and Schrecker, "The Reform Movement of 1898 and the Ch'ing-i," pp. 293-94. 
to $\mathrm{Li}$ Hung-chang, the ch'ing-i movement indirectly attacked the Empress Dowager, Tz'u-hsi, as the primary Imperial court target. ${ }^{22}$ The first change was the transformation of this ch'ing-i opposition into support focused on the Kuanghsü Emperor (r. 1874-1908), when he attained his majority in 1889. The second alteration was the ch'ing-i insistence that the yen-lu (paths of communication) be kept open between the lower bureaucratic ranks and the Emperor. ${ }^{223}$

Although it would seem difficult to connect these ideas of a conservative traditionalism to later radical reformism, it should be noted that both conservative reaction and radical reform began as opposition to the established power structure. Because opposition was opposition, regardless of where it originated, the political climate of late Ch'ing China united individuals, who would later propose contradictory solutions to the empire's problems, in overall opposition to the establishment. One illustration is the radical reformer, K'ang Yu-wei, who became acquainted with the "Pure Flow Party", through his association with Chang Chih-tung in Canton. ${ }^{224}$ The attraction for K'ang was the ch'ing-ifocus on the Kuang-hsü Emperor as the hope for a new revitalization of the Chinese bureaucracy and the ch'ing-i call for open "communication paths" between the young Emperor and newer members of the literati to establish a union for opposition to the existing power structure from above and from below. $^{225}$

As noted, K'ang Yu-wei was one of the members of the younger literati

${ }^{222}$ Schrecker, Reform in Nineteenth-Century China, pp. 292-93. To have attacked the Empress Dowager directly would have been too politically risky, because of her powerful position as an Imperial regent. Upon the death of her son [the T'ung-chih Emperor] in 1874, Tz'u-hsi adopted her nephew, Tsai-t'an, in order to reestablish her power as the regent for a minor. The new emperor, at four sui or about three years old, was enthroned as the Kuang-hsü emperor in late 1874, after Tz'u-hsi and Tz'u-an had again been named co-regents. See Hsü, The Rise of Modern China, pp. 372-73; and Mackerras, Modern China, p. 127.

${ }^{223}$ Schrecker, "The Reform Movement of 1898 and the Ch'ing-i," pp. 293-94.

${ }^{224}$ Schrecker, "The Reform Movement of 1898 and the Ch'ing-i," pp. 294-95.

${ }^{225}$ Schrecker, "The Reform Movement of 1898 and the Meiji Restoration as Ching-i Movements," pp. 99-100. Schrecker notes that the Kuang-hsũ Emperor encouraged the development of relations with the ch'ing-iadherents in his attempt to form his own opposition to the existing power structure of the Empress Dowager and the top echelon of officials who had gained their positions during her tenures as regent. 
who was seeking a position in the late Ch'ing bureaucratic structure. K'ang (1858-1927) was born into a gentry family in Kwangtung province, south of the first port opened to Western influences, Canton. When his father died in 1868, K'ang's early education was entrusted to his grandfather, who was a chü-jen and an adherent of the Sung-hsüeh school's style of personal moral cultivation through the active duty of the scholar to society. ${ }^{226}$ After his first attempt to attain the chü-jen degree failed in 1876, K'ang entered himself under the formal schooling of one of the acknowledged Confucian scholars of the province, Chu Tz'u-hsi (1807-1881), who enlarged K'ang's Confucian study to included the philological methods of Han-hsüeh school. From the beginning of his education at home, K'ang had been described as something of a precocious eccentric ${ }^{227}$; and two years after he began his study at the school of Chu Tz'u-hsi, K'ang would add to this eccentric image. In his own record of his emotional crisis, K'ang also briefly describes the educational atmosphere of the school:

"Buried as I was every day amid piles of old papers, my mind became confused, and I gradually developed a revulsion for them. Then one day I had a new idea. I thought: 'Scholars like Tai Chen, who engage in textual research, fill their homes with the works they have written, but in the end, what is the use of all this?' Thus I gave it up, and in my own heart I longed to seek a place where I might pacify my mind and determine what would be my destiny. Suddenly, I abandoned my studies, discarded my books, shut my door, withdrew from my friends, and sat in contemplation, nurturing my mind. My schoolmates thought it very queer, for there had been no one who had done this before, inasmuch as the Master was in favor of the personally active performance of the Confucian virtues and detested the study of Ch'an Buddhism. While I was sitting in contemplation, all of a sudden I saw that Heaven, Earth and all the myriad things were all of one substance with myself, and in a great release of enlightenment I beheld myself a sage and laughed for joy; then suddenly I thought of the sufferings and hardships of all living things and wept in melancholy.... When winter came, I took my leave of

${ }^{228}$ Hao Chang, Chinese Intellectuals in Crisis: Search for Order and Meaning (1890-1911) (Berkeley: University of California Press, 1987), p. 21. Note: I am using " $h$ süeh" in the sense of "learning", therefore, the translation of the "Sung-hsüeh school" would be "the school of Sung learning" and the translation of "Han-hsüeh school" in the following sentence would be "the school of Han learning".

${ }^{227}$ Hao Chang, Chinese Intellectuals in Crisis, p. 21. 
Master Chu...."228

In the atmosphere of traditional schooling that K'ang had described (study "amid piles of old papers") it did not seem unreasonable that a young man of twenty would become discouraged with all of the detailed investigations of the Classics. However, this brief glimpse at a turning point in his youthful education also captured one aspect of K'ang's personality. Even at the early age of twenty, one can detect a certain iconoclastic arrogance in K'ang Yu-wei, a rebellious vanity which may have initially drawn him to the ch'ing-i movement and which most certainly deprived him of the later support of other erstwhile members of that movement. In fact, two of his earliest associates, Chang Chih-tung and Chang Chien, would withhold their support from his efforts during the crucial events of $1898 .^{229}$

By 1878, K'ang Yu-wei had left formal traditional schooling, but he had not left his pursuit of learning. In 1879, after a short stay in Hong Kong, K'ang returned to his family home in Nanhai, Kwangtung, with a curiosity about the Western world he had encountered in the British colony aroused. In addition to preparing for the next chü-jen examination, K'ang began to learn about the West through the 1840 geographies written by Wei Yuan and Hsu Chi-yü. ${ }^{230}$ In 1882, K'ang again came in contact with the Western world, when he visited Shanghai, en route to another chü-jen examination in Peking, and he

${ }^{228}$ Quoted in Grieder, Intellectuals and the State in Modern China, pp.83-84. Grieder noted that Tai Chen lived from 1724-1777 and was considered one of the greatest proponents of the Han-hsüeh school methodology. Briefly, Ch'an Buddhism was the Chinese predecessor of Japanese Zen Buddhism, which stressed that enlightenment could only come through individual purification of the mind and body by meditation and austere living.

${ }^{229}$ Although Chang Chih-tung's differences with K'ang resulted from their very different philosophical interpretations of Confucius and from differences on the best reform methodology to strengthen China, K'ang's personality might have influenced Chang. Basically, K'ang's method was political reform; and Chang continued to call for institutional reforms. See Ayers, Chang Chihtung and Educational Reform, pp. 138-40, 144-45. After an initial cordial relationship, Chang Chien became estranged because of K'ang's "vanity." See Chu, Reformer in Modern China, pp. 54-55. When noting these two reactions, it would not be difficult to imagine that an elite official such as Chang Chih-tung might have also been influenced by K'ang's "vanity". There will be a further discussion of K'ang's personality, his relationships with other scholars, and the possibility that he may have not been the best leader for the 1898 reformers in Chapter 3 .

${ }^{230}$ Grieder, Intellectuals and the State in Modern China, p. 83. For the books by Wei Yuan and Hsu Chi-yü, see footnote 144. 
purchased more materials on Western learning in the treaty port city. ${ }^{231}$ Among the materials that he purchased were the Kiangnan Arsenal's translations of Western works and copies of an important missionary periodical, The Globe Magazine (Wan-kuo kung-pao), which was published by an American, Young J. Allen (1836-1907). ${ }^{232}$ This periodical represented one of the missionary secularization efforts, which Allen clearly outlined in his statement of purpose for The Globe Magazine. It was an ambitious undertaking that Allen envisioned for his publication, when he wrote that it was:

"Devoted to the extension of knowledge relating to Geography, History, Civilization, Politics, Religion, Science, Art, Industry, and general progress of Western countries."233

This encounter provided K'ang with yet another turning point in his life. Previously, he had turned away from the "piles of old papers", in order to "meditate" on his own individual "joy" and "melancholy". Now he would turn away from the rigors of the examination system to feed his own "hunger for knowledge." In his later description of this period, Liang Ch'i-ch'ao wrote of this "hunger":

"Men like K'ang Yu-wei...were born and brought up in this environment of a 'hunger for knowledge,' absorbing themselves in introspective meditation and exhausting searching, in the hope of founding a new school of learning which would be 'neither Chinese not Western but in fact both Chinese and Western."'234

Liang Ch'i-ch'ao's words would seem to indicate that an important foundational shift had occurred in the Chinese intellectual climate by the waning years of the

${ }^{231}$ Grieder, Intellectuals and the State in Modern China, pp. 83-84.

${ }^{232}$ On Kang's purchase of these materials, see Hsü, The Rise of Modern China, p. 431. The translation of the publication's title is literally: "International Gazette". From 1875 to 1882, when it was first published by Mr. Allen, the English subtitle "The Globe Magazine" actually appeared under the Chinese title. When the S.D.K. revamped the publication and made it a monthly magazine, the same Chinese title was used, but the translation given for this later (1889-1907) Wan-kuo kung-pao is usually: "Review of the Times." See Grieder, Intellectuals and the State in Modern China, p. 94; and Hsü, The Rise of Modern China, p. 426. On the S.D.K., see the previous page 57; and further discussion of this group will be found in Chapter 3.

${ }^{233}$ Quoted in Grieder, Intellectuals and the State in Modern China, p. 94.

${ }^{234}$ Liang Ch'i-ch'ao, Ch'ing-tai hsüeh-shu kai-lun, p. 113. The underlining is mine for emphasis. 
nineteenth century.

Even though Chang Chih-tung had left the opposition ch'ing-i movement in order to initiate Self-Strengthening reforms in the aftermath of the Sino-French War, Western learning continued to be regarded as a separate "ad hoc" training system that could add specific techniques to the Chinese tradition. However, in 1885, the emphasis remained one of examining the technology in Western leaming. Very little interest had been shown in the wider philosophical content of that knowledge. Although he had again been writing with retrospective hindsight, Liang Ch'i-ch'ao noted an important intensification of interest in Western learning that was to be found in the less "official" attitudes of the younger intellectuals who were coming of age in this era.

What had first been demonstrated by the "new literati" in the treaty port littoral now began to penetrate the traditional core. This was the acknowledgement that other forms of Western learning beyond technology might prove beneficial to China-- knowledge such as Wang T'ao's discussions relating Western history to current events or Cheng Kuan-ying's insistence that "foreign matters are timely matters." Against this backdrop of rapidly widening intellectual horizons that had first appeared in the "cosmopolitanism" of the treaty ports, K'ang Yu-wei and other members of the second transitional generation began to look at Western learning not just as selective adaptions but also as a possible source of answers to modern China's problems. In a very different way, this was also a pattern of "official" failure at the national level and "unofficial" success at the individual level, as more young Chinese scholars were caught up in this "hunger for knowledge". 


\section{CHAPTER IV}

\section{THE SECOND TRANSITIONAL GENERATION AND REFORMS}

\section{THE INTELLECTUAL CLIMATE ON THE EVE OF THE SINO-JAPANESE WAR}

The foundational shift which had begun with the establishment of a separate "system" of specialized institutions in the Self-Strengthening Movement, in response to the "internal chaos and external troubles" of the 1840 s through the 1860 s, had been slight. However, in view of the conservative intellectual climate of the T'ung-chih Restoration, the fact that any shift occurred at all was noteworthy. In the years between the initial educational SelfStrengthening reforms and the development of the intellectual "hunger" for new knowledge among younger Chinese intellectuals that Liang Ch'i-ch'ao had remarked upon, a sizable attitudinal shift had occurred. By the time that K'ang Yu-wei was eagerly reading all that he could about Western knowledge, the fact that there were many different Chinese-language publications available to him on these subjects provided concrete evidence of this shift.

Both of these foundational shifts appeared to have had little lasting effect on the traditional system. The institutional structure seemed to weather the initial slight shift by allowing the development of separate, but certainly not equal, facilities for Western training established in a random fashion by elite reformers within their own jurisdictions. Although the glimpses of Western learning through the "windows" that treaty port intellectuals had opened even wider in the 1870 s eventually appealed to young "outsiders", such as K'ang Yuwei ${ }^{235}$, this external change of scenery had been generally ignored by the majority of traditionally educated Chinese scholars. What was now needed was

\footnotetext{
${ }^{235}$ K'ang could be considered an "outsider" at this time for two reasons. The first was the fact that he had not become a member of the scholar-bureaucracy through the examination system. The second was his connection to the ch'ing-i movement of the 1880 s. See the previous discussion of the "outsider" status of ching-iadherents in Chapter 2.
} 
a catalyst to draw the attention of this majority to the "change of situation" that had taken place outside of those opened windows. In 1895, just such a catalyst was introduced from a much closer perspective. That year witnessed the Chinese defeat at the hands of its neighbor, Japan. In the subsequent decade (1895 to 1905), China was forced to acknowledge that a change of situation had indeed occurred; and this realization would affect the society to its very intellectual and political foundations.

Although the traditional structure had remained relatively unaltered by the previous attempts at reform, certain members of the elite had been very aware of the evolving "change of situation" in their immediate surroundings. As early as 1863 , Kuei Wen-ts'an had memorialized the throne with the proposal that the country send students abroad to learn Western technologies, as the Japanese had. ${ }^{236}$ In the next decade, Japan had established its presence in what had traditionally been considered the Chinese sphere of influence, by claiming the representation of the Ryukyu Islands in a negotiated peace settlement between the former Chinese tributary state and the Chinese possession of Formosa. The Japanese had even managed to demand a reparation payment of 500,000 Taels for losses incurred in their punitive expedition against Formosa in defense of the Ryukyus. ${ }^{237}$ At that time (1874), one leading intellectual of the Tsungli Yamen, Wen-hsiang, had memorialized the throne, warning of future disaster:

"When the peace negotiations were completed [in 1860] everybody spoke of the necessity for self-strengthening, yet during the last ten years or more there has been little achievement. The reason is that those who look down upon and disregard foreign affairs merely have empty discussions without actual accomplishment, whereas those who are accustomed to the peaceful situation are content when nothing happens for fear that if anything is done it may arouse the suspicion of foreigners....Now the (Formosa) incident has already taken shape, a war crisis is imminent. If we do not pay attention to it and suddenly the great enemy (Japan) confronts us, what can we rely upon?... As for the way to

\footnotetext{
${ }^{236}$ See the discussion of Kuei's memorial on page 22 [ Chapter 1]. His proposals had been considered unnecessary at that time.

${ }^{237}$ See Fukuzawa Yukichi's article, "A Speech on the Peace Negotiations Relating to the Formosa Expedition," in the Meiroku Zasshi, (Issue Twenty-one), November, 1874.
} 
make ourselves strong, it lies in our readiness to accept advice in a humble manner in order to seek out the good and bad points in our administration....Otherwise [your ministers] will remain accustomed to taking things complacently and will never think of reforms, in which case, I fear that internally and externally the country will fall apart, the people's confidence will be shaken, and the disaster will be unspeakable." ${ }^{238}$

Even though this was the appeal of one of the earliest Manchu SelfStrengthening supporters at the Imperial court, it had obviously failed to arouse concern. In two decades, the "unspeakable" disaster predicted by Wen-hsiang would overtake a "complacent" (or at least an intellectually complacent) Ch'ing China.

Moreover, the twenty years between this warning and the predicted disaster had not been ones of uninterrupted peace. The Chinese were again reminded of a new aggressive Japanese presence in 1885, when Li Hungchang had initialed the Tientsin convention on Korea with Ito Hirobumi; yet, the defeat of China by the "barbarian" Japanese caused a "shock wave" that reverberated throughout Ch'ing intellectual circles. Liang Ch'i-ch'ao's words capture some of this anguish:

"The defeat in the Sino-Japanese War (1894-1895) produced nation-wide consternation, and assertive young men bitterly and determinedly talked of 'Renovation and Reform'; high provincial officials like Li Hung-chang... and Chang Chih-tung...gave them moderate encouragement. Among the prevailing slogans was the phrase 'Chinese learning for the fundamentals and Western learning for practical use,' which Chang Chih-tung delighted in promulgating, and which the whole nation regarded as a keynote, since the men of that time positively would not admit that the Europeans and Americans, apart from their ability to make [guns], explore [terrain], sail [ships], and drill [troops], had any other kinds of knowledge. A search of the Western works translated would also not reveal any

${ }^{238}$ Excerpted from the translation in Teng and Fairbanks, China's Response to the West, $p$. 90. 
other kinds of knowledge."239

Naturally, Liang had his own political reasons for condemning the bureaucratic "establishment", but he was also indicting the entire intellectual structure for its lack of a "hunger for knowledge".

The individual successes of the Self-Strengthening leadership in the 1870 s and 1880s had appeared to be the best way to quiet those few voices which had insistently been proposing changes. As previously noted, the SelfStrengthening agenda had changed after the 1885 treaty, ending the SinoFrench War. Li Hung-chang had concentrated most of his efforts on attempts to modernize the Chinese military ${ }^{240}$; and, even though Chang Chih-tung did establish the Self-Strengthening School (Tzu-ch'iang hsüeh-t'ang) in 1893 in response to a local magistrate's memorial on foreign language training for Hupeh tea merchants' sons, his major successful efforts had also been connected with military institutions. ${ }^{241}$

However, the fact that Chang did continue to expand the scope of instruction at the Self-Strengthening School indicated that he was developing a broader approach to Western learning than he had previously adopted. When it proved impossible to provide effective instruction in natural sciences and modern commerce because of the language problems involved, Chang wrote:

"Today when Western books with new principles and new learning are coming out increasingly, we still have no way to gain information about the splendors (they describe) or investigate their benefits and faults.... If we do not have men who fully understand foreign languages, we cannot obtain the true import of the new principles and new learning."

${ }^{239}$ Liang Ch'i-ch'ao, Ch'ing-tai hsüeh-shu kai-lun, p. 113. The translated Western works to which Liang referred were the numerous publications of the Kiangnan Arsenal. As noted, they were almost all scientific or technological works. (See footnote 141, Chapter 2). In addition, the translations and publications by Western missionaries leaned heavily toward scientific discussions. See the discussion of the reasons for the secularization of missionary publications, pp. 56-60 [Chapter 2].

${ }^{240}$ See pp. 41-2 [Chapter 1] and pp. 72-3 [Chapter 2].

${ }^{24}$ ' On the Tzu-ch'iang hsüeh-t'ang, see Ayers, Chang Chih-tung and Educational Reform, pp. 124-25. Ayers lists two military schools and two technical institutes (telegraphy and mining) as successful efforts for Chang before the Sino-Japanese War, see his list in the same source, pp. 104-105. 
Chang later turned these thoughts into an axiom, which he would incorporate into his philosophy of educational reform that would eventually transform the Chinese educational system. This 1895 axiom was:

"If one does not have a thorough knowledge of foreign languages, one cannot read Western books. If one does not read Western books extensively, one cannot attain thorough knowledge."2a2

Chang's concern about the language "barrier" was not merely another isolated response to a specific situation, such as the founding of Foreign Languages Institute had been in $1861 .{ }^{243}$ His concern was representative of two, broader, related trends in the changing intellectual climate of China in the 1890s.

The question of language difficulties in education was not a new one. Concerns voiced about foreign language instruction had influenced the curricula of both the Chinese Self-Strengthening institutions and the missionary schools. From its opening in 1862, this question about languages had shaped the curriculum of the Foreign Languages Institute. When it had become necessary to hire foreign instructors, both the Chinese and the Western instructors had displayed some concern about language and instruction. The Ch'ing officials had questioned the foreigners' sincerity in sharing Western knowledge with the Chinese students ${ }^{244}$, and the foreign teachers had debated whether to teach in Chinese or in another language that would require years of initial preparation for the students. Since many Westerners considered the

\footnotetext{
${ }^{242}$ Both quotations from Ayers, Chang Chih-tung and Educational Reform, p. 126. Chang had made an important alteration in his developing educational philosophy with this observation. Foreign language training had hitherto been one of those "specialities", with the stated intention of producing language "experts", who could become translators or act as interpreters. From his 1893-95 statements, Chang's opinion that foreign language instruction was basic to the development of "modern" education clearly indicated that the carefully erected intellectual barrier between specialized "Western" training and traditional learning was disappearing.

${ }^{243}$ The treaties ending the Anglo-French war had demanded that all future diplomatic correspondence between the victors and China must be conducted in the languages of the signatories, English or French. This requirement led to the introduction of foreign language training. (See pages 17-18, Chapter 1).

${ }^{244}$ For the Chinese concerns on hiring foreign instructors, see Chapter 2, pp. 48-9 and footnote 120 . Because the Chinese officials had not received prior language instruction, their inability to read foreign texts and compare them to lectures given in Chinese would be a logical source of suspicion.
} 
Chinese language to be unsuitable for even the introduction of the scientificallyoriented curriculum, the foreign instructors in Chinese government-sponsored schools had decided to concentrate on developing basic language proficiency first. ${ }^{245}$ This equation of language with knowledge also affected the curricula of missionary schools, where the debate over whether or not to provide foreign language training for Chinese students centered on the issue of cultural superiority. In an ironic parallel to the barrier that knowledge of wen-yen provided in traditional Confucian society, some missionaries suggested that it was necessary to erect a similar "language" barrier between themselves and their Chinese pupils, in order to protect their own status. ${ }^{246}$

The second trend which was beginning to emerge was a growing sense of urgency. Compared to the pace of establishing new educational institutions (seven in twenty-five years) between the signing of the 1860 treaties with victorious Anglo-French forces and the signing of an 1885 treaty acknowledging the French "rights" in Annam, Chang Chih-tung's rate of founding new schools (ten in eleven years) from 1885 to 1896 demonstrated a considerable acceleration in the development of an "ad hoc" system. ${ }^{247}$ In this same period of time, the Society for the Distribution of Christian and General Knowledge (Kuang hsüeh hul) or S.D.K., had been organized in Shanghai (1887) to

${ }^{245}$ On the Western argument that the Chinese language was unsuitable for scientific instruction, see Davin, "Imperialism and the Diffusion of Liberal Thought," in Hayhoe and Bastid, China's Education and the Industrialized World, p. 40. Davin notes that this attitude persisted into the 1890s and that John Fryer's contributions to the development of a Chinese "scientific vocabulary" eventually changed this attitude. For the "scientific" orientation of the curriculum, see Chapter 2, pp. 52-3. On the decision to concentrate on foreign language instruction, see Biggerstaff, The Earliest Modern Government Schools in China, pp. 82-83. The governmentsponsored schools were: the Peking and Canton T'ung-wen kuans, the Shanghai Kuang fangyen kuan, and the Foochow Ch'uan-cheng hsüeh-t'ang.

${ }^{246}$ See the previous discussion on the social barrier created by wen-yen in Chinese society (Chapter 2, pages 59-60). The "irony" was that wen-yen had effectively prevented the earlier missionary efforts to interest Chinese scholar-officials in Western learning. An example of this desire to maintain "cultural distance" was the question directed at Timothy Richard in 1885. Jerome Ch'ên notes that the (unidentified) German Minister of Education asked: "And when you have educated the Chinese nation what will become of us?" See his China and the West, pp. 124-25.

247 See a list of these institutions and their locations in Ayers, Chang Chih-tung and Educational Reform, pp. 105-106. 
promote secularized Western learning. One vital communication link to the emerging transitional generation was the renewed publication (1889) of the Review of the times (Wan-kuo kung-pao), which the S.D.K. distributed for free or a nominal fee throughout China at provincial capitals during the time that the triennial civil service examinations were held. ${ }^{248}$ The addition of the new editor, Timothy Richard, helped to establish links with influential officials, such as Chang Chih-tung, and added prestige to the Review of the times and to the other S.D.K. reform suggestions. ${ }^{249}$ One such innovation was the S.D.K. sponsorship of an 1894 essay competition for all chü-jen candidates on "reform" issues, such as the advantages for China of a railway system or an efficient Imperial customs service or suggestions on halting opium trafficking or improving China's international relations. A 600 Tael prize was offered for the best essay. ${ }^{250}$

Although it appears that the prize was never awarded, the fact that this competition was even allowed to be held in connection with such an established educational tradition as the examination system indicated that a consensus on the necessity for some institutional reform had developed among top echelon officials. Any agreement at this level of the intellectual elite could be

\footnotetext{
${ }^{248}$ Scalapino and Yu, Modern China and lits Revolutionary Process, p. 80.
}

249 The connection between Timothy Richard and Chang Chih-tung dated from Chang's governorship of Shansi province in 1882, when he contacted the missionary regarding specific reforms suggested by Richard. See footnote 212 [Chapter 2] and Ayers, Chang Chih-tung and Educational Reform, p.102. Jerome Ch'ên notes that the S.D.K., under Richard, became the "most influential publishing house" in China from the 1890s to W.W. I and even worked with the Ch'ing government on the editing of textbooks after 1905. See his China and the West, p. 117

${ }^{250}$ Scalapino and Yu, Modern China and Its Revolutionary Process, pp. 80-81. Although I have been unable to locate the name and essay topic of the winner (if any), the 600 Tael prize must have created considerable interest among chü-jen candidates. Cleverly has estimated that the costs for progressing through the system to the chin-shih degree came to exactly that amount. See the discussion and footnote 14 on page 8 [Chapter 1 ]. 
said to represent a "national"251, or at least a bureaucratic, climate for reform in late nineteenth century China.

\section{NEW VOICES IN THE DEVELOPING REFORM MOVEMENT: SERIOUS QUESTIONS AND GROWING CONCERNS}

If this consensus on the need for reform had occurred even five years earlier, it would have represented a significant victory for the advocates of reform among the first transitional generation. However, in the Chinese intellectual climate of the 1890s, it merely represented an official confirmation of a general trend. If there could be said to be a characteristic common to the range of Chinese intellectual attitudes in this decade, it would have been that the forum on reform had shifted from a debate over the question of necessity to one over the question of implementation.

Although the types of questions being raised and the reforms being proposed by the members of the second transitional generation in the tumultuous intellectual atmosphere of the 1890s appeared to underscore the general failure of the Self-Strengthening Movement, they had actually developed out of the educational legacy left by those individual successes of the first transitional generation. One central question concerned the nature of historical development.

${ }^{251}$ The adjective "national" is used in the specific sense of the elite government system in late Imperial China. The development of a concept of "modern" nationalism (in the sense of a Western political entity or a nation-state) in the collective Chinese consciousness is a fascinating topic beyond the scope of this study. However, a sense of cultural identity had always been part of the Confucian world view, which had been institutionalized as the tribute system. Briefly, this world view posited that the Confucian monarch of Imperial China was the medium through which the blessings of heaven (civilization or culture) were bestowed on the surrounding tribute states. Therefore, traditional state relations had been based on the concept of shared Confucian culture, not on the concept of different political entities. See John K. Fairbank, "Synarchy Under the Treaties," in John K. Fairbank, [ed], Chinese Thought and Institutions (Chicago: University of Chicago Press, 1957) pp. 211-12. 
When K'ang Yu-wei temporarily withdrew ${ }^{252}$ from the rigorous path of the examination system in 1883 , he did not also abandon scholarly pursuits. In the manner of a traditional Confucianist, K'ang undertook a course of self-study in order to understand the present through an investigation of historical development. However, the way in which he went about this investigation involved some very nontraditional sources. In his autobiography, K'ang noted that he had studied: Ch'ing statues and edicts; histories of Sung, Yuan, and Ming Confucianism; Chu Hsi; and a variety of Western subjects, such as "acoustics, optics, chemistry, electricity, and mechanics, as well as histories and travelogues." Moreover, after noting this unusual combination of sources, K'ang went on to record what can only be described as the use of a nontraditional methodology in his investigation:

"My thoughts wandered far into the mystery and infinity of space and time. I gathered the deep and more abstruse statements in the classics and in the other philosophic works, examined hidden meanings in Confucianism and Buddhism, studied new ideas in China and the West traced the evolution of man and nature, compared the tenets of various religions, pored over maps of the world, reviewed the present and the past in order to see the pattern of the future...."253

In this short excerpt, K'ang had demonstrated just how far the Chinese intellectual foundations had already shifted. The most obvious shift from traditionalism was K'ang's study of the "new ideas". In the Analects, Confucius had warned against the danger in studying "strange doctrines". Less obvious, but more important, were the intellectual shifts indicated by K'ang's comments about "tracing evolution" and looking for a "pattern of the future". Both of these methodologies can only have developed from nontraditional sources. The traditional Chinese concept of history was one of cyclical fluctuation between yin and yang and had not developed a theory of evolutionary change leading

\footnotetext{
${ }^{252} \mathrm{He}$ reentered the examination system in 1893 , when he attained his chü-jen degree (Canton) and progressed on in 1895 to pass the chin-shih examination (Peking). K'ang's major classical study in the late 1880s and early 1890s was in the New Text Movement, which will be outlined in a following discussion of his teaching relationship with Liang Ch'i-ch'ao.
}

${ }^{253}$ Both excerpts from K'ang's autobiography are in Grieder, Intellectuals and the State in Modern China, p. 111. Underlining is mine for emphasis. 
from the past through the present to the future. ${ }^{254}$ Although, K'ang would eventually return to a historical tradition based in Confucianism, there can be no doubt that his earlier exposure to the altered intellectual foundation affected his mature concepts of change and development. ${ }^{255}$

Another question, which was related to theories of historical change, was that of what part history (or historical traditions) could play in changing the present Chinese situation. A decidedly negative answer was proposed by one of the earliest "returned students" who had studied abroad, Yen Fu (1853-1921), who had returned to China from his studies in England in 1878 and had entered the traditional civil service as a teacher at his home institution, the Foochow Naval Shipyard School. Two years later, Yen was promoted to the position of administrator for the newly established Tientsin naval school, under Li Hungchang. Yen used his knowledge of China and the West to assess the differences in their intellectual traditions and his essay, Lun shih-pien chih-ch'i (The perilous changes in the world) was not optimistic:

"I think the greatest difference between China and the West, which can never be made up, is that the Chinese are fond of antiquity but neglect the present. The Westerners are struggling in the present in order to supersede the past. Chinese consider a period of order and a period of disorder, a period of prosperity and a period of decline, as the natural course of heavenly conduct of human affairs; while Westerners consider that daily progress should be endless, and that what has been prosperous will not decline, and that when things are well governed, they will not be in disorder again -- all of which they take as an absolute law of academic thought and political ideas." ${ }^{1256}$

Even though this assessment was preceded by a brief cataloging of the successes achieved during the preceding Self-Strengthening Movement, Yen

${ }^{254}$ It should be noted that Hsüeh Fu-cheng had developed a theory of linear historical change in his 1885 essay, "On Reform". See the previous discussion of Chinese historical concepts on pp. 73-5, Chapter 2.

${ }^{255}$ Wing-tsit Chan has noted that K'ang's signature work, the Ta-t'ung shu (Book of the great unity), in which he proposed his historical theory of the Three Ages, was developed from Chinese intellectual tradition and made K'ang a part of that tradition. Although his theory can be traced back to the Han Confucian synthesizer, Tung Chung-shu, K'ang's methodology of evolutionary rather than cyclical change was novel. See Chan, A Source Book in Chinese Philosophy, p. 724

${ }^{256}$ Cited in Teng and Fairbank, China's Response to the West, pp. 150-51. 
implied that no substantial change had actually occurred in the Chinese intellectual foundation. However, the very fact that he had acquired his knowledge of Western "academic thought" through one of those earlier programs might have been a more accurate measure of the real achievements in educational reform by the first transitional generation.

In answer to the central question of this decade, which was how to implement the necessary reforms, Yen also based his answer on his considerable knowledge of Western political concepts. In an 1895 essay, Yüan ch'iang (On power), Yen proposed a political answer based on universal human experiences ${ }^{257}$, such as survival, self-image, and morality:

"[The term] 'struggle for existence' means that living things struggle to survive; 'natural selection' means that the fittest species survive. The idea is that people and other living things are intermingled in the world, all feeding themselves from the environment and the benefits of nature. When they come into contact, they contend with one another, struggling with each other in order to survive.... The weak are consumed by the strong, and the ignorant are made subservient to the intelligent. Species which succeed in surviving must be tenacious and hardy, agile and sharp-witted, the best-fitted to the climate, the geographical conditions, and the human affairs of the time....

"To be specific, wealth and power are nothing more than benefiting the people. If the government wants to benefit the people, it must begin by enabling each person to benefit himself, and the beginning of each person being able to benefit himself is freedom for everyone.... For this reason, the policies urgently needed at present consist of three fundamentals: 1) encourage the people's energies; 2) enlarge their intelligence; 3) renovate their morality....

"The doctrine of the West is equality. Hence, the common good is used to govern the masses. And so freedom is esteemed, trust and achievement are valued. The doctrine of the East is the principle of human bonds. Hence, filial piety is used to rule the empire, and primacy is given to respect for parents. And because parents are respected, trust and achievement are slighted....Whenever I hear Englishmen talk about England, Frenchmen talk about France, or anyone mention the land of his birth, they say the name in the same tone of voice we utter our parents' names, with sincerity and solidarity, with what seems to be 
unbounded love....But how are we to make each person think of China as his own [parent]? By establishing a legislature in the capital, and ordering the provinces and districts of the empire to publicly select local officials." ${ }^{258}$

Thus, Yen introduced the Darwinian theory of "natural selection" (in its Spencerian social philosophy form) as the basis of Western "political strength", with the implication that only by radical political reforms could China meet the challenges in the current "struggle for existence" and build a sense of national identity, as the English and the French had done.

During the decade of the 1890s, Yen Fu was also engaged in introducing other Western concepts to the Chinese literate elite. In his first published translation of a Western book, Alexander Mitchie's Missionaries in China, Yen helped to acquaint Chinese scholars with the fact that not all foreigners thought alike. Not only did some Westerners disapprove of the missionary work in China, some of them were not even Christians. By showing that there were differences in Western thought, Yen was also introducing the concept that not all foreign thought was based on religion. ${ }^{259}$ For young Chinese intellectuals, whom Liang Ch'i-ch'ao had characterized as a "hungry for knowledge", the menu had suddenly been enlarged to include Western secular thought, untainted by the despised Christianity.

Yen subsequently obtained fame in China and exerted tremendous influence over the late Ch'ing intellectual climate through his annotated

${ }^{258}$ Excerpted from Gentzler, Changing China, pp. 84-86. The underlining is mine for emphasis. Gentzler gives the title, "On Power". In his discussion of this essay, Wang listed the Chinese title and the translation, "On Strength," in his Chinese Intellectuals and the West, pp.195-98. Wang notes that this essay and the previous one were in a series of four "political essays" published in Tientsin in a German-owned Chinese newspaper at the end of the SinoJapanese War. The titles and topics of the other two essays were: Chiu-wang chüeh-lun (Views on how to save the country), an attack on the traditional education system; and P' Han ( $A$ refutation of $H a n Y \ddot{~})$, an attack on the Chinese monarchical system through a critique of the T'ang dynasty essayist, Han Yü, who had written about the need for a strong emperor. Wang, Chinese Intellectuals and the West, p. 200.

${ }^{259}$ Delia Davin, "Imperialism and the Diffusion of Liberal Thought," in Hayhoe and Bastid, China's Education and the Industrialized World, pp. 38-39. 
translations of famous Western philosophical works. ${ }^{200}$ Even before the 1896 publication of his most famous work, Huxley's On Evolution and Ethics, circulation of a manuscript created a sensation among the "hungry" young intellectuals of the second transitional generation. In an age where the use of language still presented a formidable social barrier, the proof of the influence of Yen Fu's version of Social Darwinism, which was written in the traditional elegant literary style, could be found in the fact that people of all social classes throughout China knew and discussed the basics of this theory in the early twentieth century. ${ }^{261}$

One of these young intellectuals who was influenced by this work was Liang Ch'i-ch'ao (1873-1929). Liang was born in Kwangtung province, near the same area that had already produced two members of the second transitional generation, K'ang Yu-wei (1858) and Sun Yat-sen (1866). His father, a shengyüan, was the local schoolteacher ${ }^{262}$, who probably gave his son his educational foundation. Whether due to his father's instruction or to his own intelligence, Liang was a precocious achiever, who attained the sheng-yüan degree at the age of eleven and passed the chü-jen examination in 1889 , at the

${ }^{260}$ Liang Ch'i-ch'ao lists the following translations by Yen Fu: T.H. Huxley's Evolution and Ethics; Adam Smith's The Wealth of Nations; John S. Mill's A System of Logic, and On Liberty, Charles Montesquieu's De l'esprit des lois; and Herbert Spencer's The Principles of Sociology. See Liang, Ch'ing-tai hsüeh-shu kai-lun, p. 114. All of these translations appeared before the 1911 Revolution. After that event, the only Western work that Yen discussed was Rousseau's Social Contract, on which he wrote a critical essay. Grieder notes that Yen annotated his translation of Huxley's work and published it with the title, T'ien-yen lun (On evolution). Although he had managed to to influence a generation through his translations, Yen's official career was unspectacular. Both Grieder and Wang point to the fact that Yen had continually failed to achieve status through passing the examinations as a reason for his growing dissatisfaction with the Imperial system. Wang notes that Yen had even purchased a degree (chien-sheng) in an effort to move ahead more rapidly, but that this had little effect on his career. See Grieder, Intellectuals and the State in Modern China, pp. 149-50; and Wang, Chinese Intellectuals and the West, p. 195.

${ }^{261}$ Delia Davin states that "Mao Tse-tung appears to have read some of them in his home town of Changsha in 1911-12." See Her "Imperialism and the Diffusion of Liberal Thought," in Hayhoe and Bastid, China's Education and the Industrialized World, p. 38. Wang has written that Yen was a man who wished to have little to do with the Chinese public and who admitted that he had deliberately used a difficult literary style in order to "limit his audience." Wang, Chinese Intellectuals and the West, pp. 211-12.

${ }^{262}$ On the status of the sheng-yüan and their service as teachers in the village schools (Shu$h$ süe $h$ ), see the discussion on traditional education in Chapter 1, pp. 8-9 and footnote 15. 
age of sixteen. However, the next year, his failure at the chin-shih examinations would prove to be a turning point for the young Confucian scholar. On his return from the metropolitan examinations at Peking to Kwangtung, Liang stopped in Shanghai, where he was introduced to Western learning through Hsu Chi-yü's dated geography, A Short Account of the Maritime Circuit and several translations from the Kiangnan Arsenal. ${ }^{263}$ Liang's words seem to indicate that this was a moment of significance for him. He wrote: "Then for the first time I learned of the five continents and their various countries...I coveted these books and could not resist buying them."264

In 1890, Liang met K'ang Yu-wei in Canton. In Liang's version of the meeting, he and a fellow-scholar, Ch'en Ch'ien-ch'iu, were "curious" about this "eccentric" and went to see him. It must have been a momentous occasion, because Liang wrote:

"At first sight, they were thoroughly taken with him and formally became his students, urging him to open a school and give lectures. The [school] was [later] known as the Wan-mu ts'ao-t'ang ("the grass hut amid a myriad of trees"). After studying there for several months, the two...severely attacked the old learning; not a day went by that they did not argue with their elders and contemporaries.

'K'ang did not lightly impart his knowledge to others.... [Liang then describes

${ }^{263}$ Hsu's book had been published some forty years earlier, in 1849. See the footnote[147] on these early geographies [p. 58, Chapter 2]. On Liang's introduction to Western learning, which seemed to parallel K'ang Yu-wei's earlier activities, see Grieder, Intellectuals and the State in Modern China, pp. 159-60. In his survey of the intellectual climate in Ch'ing China, Liang specifically mentions the Kiangnan Arsenal translations by Li Shan-lan, Hua Heng-feng, and Chao Chung-han in his Ch'ing-tai hsüeh-shu kai-lun, p. 113.

${ }^{264}$ Quoted in Grieder, Intellectuals and the State in Modern China, p. 160. 
the Classical curriculum of the Modern Text Movement ${ }^{255}$ ] Frequently old ceremonies were performed too, and since Ch'en and Liang had little taste for this, they changed to the study of Chou and Ch'in philosophers and the Buddhist scriptures; they also browsed through various political works by Ch'ing scholars as well as translations of Western works, turning to K'ang for solutions to their problems...."266

As he indicated, Liang was much less interested in the profound scholastic investigation of the New Text Movement than his teacher was. Perhaps he was merely displaying the young student's aversion to being "buried...amid piles of

${ }^{265}$ In these years, K'ang Yu-wei was involved with a historical controversy over the authenticity of the texts ( the Wu-ching or Five Classics) which formed the core of Confucianism. Very briefly: this controversy dated from time of the Han dynasty, when scholars had attempted to reconstruct the Confucian texts, which had been destroyed in the great book-burning ordered by Ch'in Shih-huang-ti, the first Chinese emperor, in 213 B.C.E. When "copies" (the Ancient Texts) of the Classics were later discovered, the Han reconstructions (the New or Modern Texts) fell into disfavor. The differences between the two versions had fueled scholarly debates from the Han dynasty to the Sung, when Chu Hsi had established his synthesis of Neo-Confucianism on the Ancient Texts. In the latter half of the Ch'ing dynasty, the debate resurfaced, and K'ang Yu-wei joined in the scholarly philological study. In Liang's assessment, K'ang's work within the New Text Movement promoted a climate for reform in four ways: 1) "both Han and Sung learning were rejected, and this opened up new frontiers to the academic world"; 2) "it encouraged men's creative spirits"; 3 ) 'the entire corpus of the true classics... was now laid open to question to its very foundations"; and 4) the study "relegated Confucius to the rank of other philosophers,...leading men into comparative studies." Liang, Ch'ing-tai hsüeh-shukai-lun , p. 95. The significance of the New Text Movement to this study is that it indicated the depth of the research among traditional scholars into their inherited intellectual tradition in their search for answers to the current problems in China. It also indicated that some nineteenth-century Chinese scholars were beginning to question their own tradition, anticipating Ch'en Tu-hsiu's New Culture Movement of 1915.

${ }^{266}$ Liang, Ching-tai hsüeh-shu kai-lun, p. 99. There is some controversy about the date of the founding of K'ang's school in Canton. Liang states that he met K'ang in 1889-90 and immediately joined his school (p. 99). Grieder identifies the founding date of the school as 1895, after K'ang and Liang had returned from the chin-shih examination in Peking (p. 117). However, Grieder also states that Liang met K'ang in Canton in 1890 (p.159). Wang doesn't mention a specific date, but notes that Liang met K'ang "soon" after he had encountered Western learning in Shanghai in 1890 (p. 212). Teng and Fairbank state that Liang was already K'ang's student when they went to Peking in 1895 (p. 148). Hsü gives 1891 as the date of the founding of the school, after Liang had become K'ang's student at the age of seventeen, which would have been in 1890 (p. 430 ). See Liang, Ching-tai hsüeh-shu kai-lun; Grieder, Intellectuals and the State in Modern China; Wang, Chinese Intellectuals and the West; Teng and Fairbank, China's Response to the West; and Hsü, The Rise of Modern China. K'ang and Liang must have been acquainted before the chin-shih examinations in 1895 , because they worked together to present a memorial to the throne at that time. Perhaps, K'ang's instruction of students, such as Liang, began informally in 1890 or 1891 and was formalized in the founding of the school in 1895. 
old papers" that K'ang had also faced over a decade earlier. ${ }^{267}$ However, in his own words, Liang "had a burning 'desire for knowledge' and a great variety of interests" which led him "to be extensive and thus superficial". ${ }^{268}$ Whatever their intellectual differences, the two scholars were united at this time in the burgeoning current for reform.

In the 1890s, this current for reform was also influencing men who lived in the littoral areas of China. From 1887 to 1892, Sun Yat-sen was enrolled in the College of Medicine for Chinese in Hong Kong, where he had also engaged a tutor in Classical Chinese and the dynastic histories, in order to add some traditional learning to his predominantly Western education. ${ }^{269}$ While he was in Hong Kong, Sun had become acquainted with a fellow young Chinese, Yang Ch'ü-yün, who was also concerned about the situation in their homeland. ${ }^{270}$ In 1892, Yang founded a Chinese patriotic organization, The Chinese Patriotic Mutual Improvement Association, with six stated aims. Among these were two that were directly related to educational reforms: "to improve in all possible ways Chinese and foreign learning from both a civil and military point of view", and "to obtain a good knowledge of Western science and learning". The intention of these educational reforms was "to learn how to be and act as a

${ }^{267}$ See K'ang's autobiographical statement on pp. 85-6, Chapter 2.

${ }^{268}$ Liang makes some very interesting observations on the differences between himself and K'ang, which would eventually lead to their political estrangement. See his "Contrast between K'ang and Liang," in Ch'ing-tai hsüeh-shu kai-lun; pp. 102-107.

${ }^{269}$ Sun had attended a traditional school in his native village in Kwangtung, but he had left in 1879 , at the age of twelve, to join his brother in Hawaii, where he continued his education at a missionary school, under English instruction. By adding Classical learning to his Western education, Sun could be said to have reversed the educational process of the other members of the second transitional generation. See Wilbur, Sun Yat-sen, Frustrated Patriot, pp. 11-12.

${ }^{270}$ Unlike Sun, Yang had been born outside of his native land, in Hong Kong, where his father was a school teacher. Yang's education was definitely nontraditional. See Chün-tu Hsüeh, "Sun Yat-sen, Yang Ch'ü-yün, and the Early Revolutionary Movement in China," in Chün-tu Hsüeh [ed], Revolutionary Leaders of Modern China (New York: Oxford University Press, 1971), pp. 102-103. 
patriot, and how to wipe out the unjust wrongs our country has suffered."271 Although Sun did not join this organization, he did appear to share the reformist attitudes of its founder. Two years later, Sun's reformist concerns became the focus of his life, when he abandoned his young medical practice in Canton to travel to Tientsin, in order to hand-deliver a letter on reform to Li Hung-chang. In the letter, which was actually in the form of a traditional memorial, the power of the West was attributed to four factors, all of which China had to develop immediately in order to meet the challenges of the West.

The fundamental required reform was an educational program that had a practical relationship to realities, so that "what one studies as a youth he will practice as an adult, and what one excels at in his studies he will be appointed to work at." The second factor was the best utilization of the land, which could be promoted by direct government activity in agriculture and the development of a network of schools to teach agricultural subjects and natural sciences. The third requirement was to develop China's natural resources through the study of science. The final reform must be in the expansion of trade, which would require the cooperation of government and commercial interests. Although the letter would conclude that the critical problem of overpopulation made it necessary to deal with agricultural reform first, China's fundamental need was the educational development of jen-ts'ai (men of talent). ${ }^{272}$

Although his personal approach (in the form of a hand-delivered letter to such an exalted official as Li Hung-chang) was unusual, the content of Sun's message was neither radical nor really political. In the 1860s, Feng Kuei-fen had argued that China needed to "adopt" Western knowledge in order to attain "prosperity and strength", which would correspond to Sun's factors of promoting

${ }^{271}$ The Chinese name was the Fu-jen wen-she, which was translated as "Fu-jen Literary Society" in Chün-tu Hsüeh, "Sun Yat-sen, Yang Ch'ü-yün, and the Early Revolutionary Movement in China," Revolutionary Leaders of Modern China, pp. 103-104. "Fu-jen wen-she" might have been translated as "Literary Society To Enrich Man". This is a Mandarin romanization for the Chinese characters. Since the society had been formed in Hong Kong, the pronunciation of the same characters would have sounded quite different in the original Cantonese. I have been unable to find that Cantonese title. It would have been interesting to learn if the original Cantonese came any closer to the English title given above.

${ }^{272}$ For a detailed discussion of the letter, see Michael Gasster, Chinese Intellectuals and the Revolution of 1911 (Seattle: University of Washington Press, 1969), pp. 11-13. 
agriculture, developing natural resources, and expanding trade. In the $1870 \mathrm{~s}, \mathrm{Li}$ Hung-chang had argued for both a change (pien-fa) of institutions and the proper "use of men" (yung-jen), which could be compared to Sun's proposals that the government must take an active role in agriculture and trade and that education and government service be connected, so that "what one studies as a youth he will practice as an adult, and what one excels at in his studies he will be appointed to work at." In the 1880s, Cheng Kuan-ying had issued a bitter challenge ("May we not then get on with it...?") in his essay pointing out the deficiencies in the Chinese attitude toward reform. Sun's proposals can been seen as a reasonable response to that challenge. This 1894 memorial-letter and Sun's personal quest indicated just how wide the intellectual climate for reform had become in 1890 s China. From the top echelon of elite reformers inside the traditional bureaucratic structure to Westernized intellectuals who were (theoretically) on the outside of the system, there had developed a common interest in reforming the state through education in order to save the country. Educational reformism had swept the country. ${ }^{273}$

Sun Yat-sen did not gain an audience with Li Hung-chang, and this failure clearly was a turning point for Sun, who abandoned his efforts at educational reform to become a proponent of political revolution, when he left China to return to Hawaii, where he established his first revolutionary society, the Revive China Society (Hsing-chung hui ) in 1895. While these events could be seen as a clear indication that the efforts to reform the traditional educational system were failing to address the real problems of China, a case can be made that Sun had chosen the wrong time to make his proposals and the wrong person to receive his appeal.

In 1894, political events had again played a role in changing the course of educational reform in China. War again was becoming imminent due to the continuing pressures of Japanese interests and activities in Korea. This tributary

\footnotetext{
${ }^{273}$ Harold Schiffrin has written an extensive account of the events and personalities involved in Sun Yat-sen's efforts to contact Li Hung-chang. Among the people that Sun contacted were Cheng Kuan-ying and Wang T'ao in Shanghai, indicating that there was some type of loose association among the treaty port intellectual reformers. Schiffrin notes that Sun was also seeking a position with $\mathrm{Li}$, and that the failure of his quest for a position may have accounted for his political radicalization rather than the failure of his reform proposals to gain a hearing. See Harold Schiffrin, Sun Yat-sen and the Origins of the Chinese Revolution, pp. 34-39.
} 
state was actually a part of Li's jurisdiction, due to his position as Commissioner of the Northern Ports. By the eve of this new aggression on Chinese territory, although the first transitional generation had established themselves in positions of considerable local power, they had achieved their status as reformers through individual efforts and may not have been able to change their own professional styles in order to work as a group, much less work with the younger reformers of the second transitional generation, such as K'ang Yu-wei, Liang Ch'i-ch'ao, and Sun Yat sen. ${ }^{274}$

At the end of the Sino-Japanese War, Li Hung-chang was nearing the age of seventy-five, having devoted almost half a century to the service for the Ch'ing court. He was clearly tired and concerned about what his individual legacy would be, when he wrote in his diary, after returning from the 1895 peace negotiations at Shimonoseki:

"In one's old age it is terrible to be beset by troubles, worries, and base falsehoods. I should not mind my physical ills at all, at least but very little, if the lies and dissatisfactions which seem to fill the very air could be gathered into a heap and go up in smoke as do the offering papers. Still, there is to me a great personal satisfaction in what I have accomplished, and within my own heart I feel that not in all my days have I had the right more than now to be proud of my labours for China....Some men would not care what posterity might say or think of them, but after all these years of mine of ceaseless endeavour, both to help the nation and to build up a name for myself, I cannot bear to think that coming generations

${ }^{274}$ The Confucian ideal had always been of the individual "superior man", who could affect society through his own personification of morality in his individual efforts for the throne. Although Chang, Li, and Liu might have been loosely connected through their commitments to reform, they were not always in agreement about political ideas. In 1880, the debate over the Treaty of Livadia with Imperial Russia, Li and Liu were identified with the "peace party" and Chang with the "war party" (the Ch'ing-liu tang) which considered Li as its number one opponent [See footnote 105, Chapter 1]. During the Sino-Japanese War, Chang had been appointed to fill the position temporarily vacated by Liu, when he went north for military defense. While in Nanking, Chang founded a military academy and organized a modern army. When Liu returned, both the academy and the army were neglected. There are other incidents, such as the competition to acquire young men of talent for their personal staffs. See Ayers, Chang Chih-tung and Educational Reform, pp.66-69, 88-89, 113-15; Hsü, The Rise of Modern China, p. 346; and Wang, Chinese Intellectuals and the West, pp. 298-99. Wang makes the point that Yüan Shih-k'ai concentrated his efforts in building his personal relationships in the military during this time. In addition to this importance placed on individual efforts, coordination of programs among different provincial authorities required an active promotion of reform at the center; and the Imperial court continued to be indifferent, if not actively opposed, to reform projects at this time. See Bays, China Enters the Twentieth Century, p. 13. 
might regard me in any light other than a patriot who attempted well and did not always fail...."275

This same conception of individual effort also was evident in the personal blame which $\mathrm{Li}$ had assumed in response to a question on the general lack of Chinese reforms posed by the Japanese representative, Ito Hirobumi, in Shimonoseki, when they had met to negotiate over Korea for the second time in ten years.

Ito had questioned $\mathrm{Li}$ as to why there had not been a single change or reform in China in those ten years. Although diplomatic, Li's response seemed both personal and honest:

"At that time when I heard you, sir, talking about that, I was overcome with admiration, and furthermore I deeply admired, sir, your having vigorously changed your customs in Japan so as to reach the present stage. Affairs in my country have been so confined by tradition that I could not accomplish what I desired. At that time time you advised me and said, 'China is large and populous, the reform of various policies ought to come gradually.' Now in the twinkling of an eye ten years have gone by, and everything is still the same. I am even more regretful. I am ashamed of having excessive wishes and lacking the power to fulfill them...."276

Li Hung-chang appeared to have been spending some time in retrospective musing over his individual legacy to both his country and reform efforts. In this last decade of his long career, it would appear that Li had neither the inclination nor the energy to head a new reform effort.

Moreover, the other great "Viceroys" were also aging. Chang Chih-tung was nearing sixty and had been a scholar-bureaucrat for more than half of his years. Liu K'un-i, at sixty-five, had served the Ch'ing throne from the time of the Taiping Rebellion, and was considered more conservative than the other

${ }^{275}$ From Mannix, Memoirs of Li Hung Chang, pp. 97-99. It was apparent that even at this later date, $\mathrm{Li}$ considered his Self-Strengthening efforts those of an individual and not as part of a movement (yün-tung).

${ }^{276}$ Excerpted from the translation by Teng and Fairbank, China's Response to the West, $p$. 126-27. As to the honesty in the negotiations, Li wrote in his diary of an initial conversation between himself and Ito: "Count Ito, you and I have together gone over this Korean question before, and we were able to understand each other perfectly, because we spoke frankly, and I hope these present negotiations will be conducted in a similar manner..." in Mannix, Memoirs of Li Hung Chang, p. 108. 
Viceroys in his approach to "Western Affairs". 277 If a new reform effort was possible, the energy for that movement would have to be found among the younger intellectuals.

In 1895, there appeared to be just that type of necessary energy. The capital was filled with young scholars, who were there for the triennial chinshih examinations and among these aspiring scholars were K'ang Yu-wei and Liang Ch'i-ch'ao. Seizing the time and the opportunity, the two young reformers wrote a 10,000 word memorial and circulated it among the other chü-jen, collecting 603 other signatures. ${ }^{278}$ This memorial was called the "Petition from the degree candidates" (Kung-che shang-shu) and presented three urgent proposals. The first two were what could be expected of ardent young men filled with patriotic fervor ${ }^{279}$ : reject the Treaty of Shimonoseki and continue the war, after moving the capital away from the possibility of battle. However, the third proposal was an emotional demand for reform: "If the institutional reform had been undertaken earlier, there would be no disaster today; if the institutional reform is undertaken now, it can avert future disaster; if not, the future disaster will be worse that the present one." ${ }^{200}$ Whether K'ang and Liang were aware of it, their prediction of disaster was an eerie confirmation of Wen-hsiang's

${ }^{277}$ The "conservative" label was applied to Liu by the North China Herald at the time of the 1894-95 war. See Chu, "China's Attitudes Toward Japan," in Iriye, The Chinese and the Japanese, p. 75.

${ }^{278}$ Hsü gives this figure, with the footnote that it has frequently been misstated as 1,200 or 1,300. See his The Rise of Modern China, p. 436. Grieder uses the figure of 1,200 in Intellectuals and the State in Modern China, p. 117. It seems probable that 1,200 or 1,300 was the total number of chü-jen in the capital for the examinations and that 603 actually signed the memorial.

${ }^{279}$ Hao Chang termed this feeling of patriotic unity among young intellectuals in response to foreign aggression a "reactive" nationalism or a sense of national identity prompted by external events, such as imperialism. He has identified a second form of unity that also appeared as "ethnic" nationalism or a sense of identity in response to the internal Manchu dominance. See Chang, Chinese Intellectuals in Crisis, p. 2. The literal translation of the petition's title is "Degree candidates who came on public conveyances" and refers to the fact that the aspirants had not yet achieved the status which would allow them to travel to the capital with their own private retinues.

${ }^{280} \mathrm{Hsü}$, The Rise of Modern China, p. 436. The proposed institutional "reforms" were actually sweeping changes in virtually every facet of Chinese life -- in the commercial, financial, agricultural, educational, and political structures. See Chesneaux et al., China From the Opium War to the 1911 Revolution, p. 309. 
memorial on a similar subject over twenty years earlier.

Although K'ang's memorial would get no further than the Imperial Censorate, a later memorial from the new chin-shih was duly forwarded to the young Kuang-hsü Emperor, who was so impressed that he had the memorial copied and distributed to the court and high provincial officials. ${ }^{281}$ In this third memorial ( May 29, 1895), K'ang had proposed a change (pien-fa) in methods or reform of the standard of educating students. The successful passage of this recommendation through the bureaucratic channels could be seen as a confirmation that the need for educational reform had finally gained general acceptance among the bureaucratic elite. ${ }^{282}$

\section{THE SPREAD OF REFORMISM THROUGHOUT THE INTELLECTUAL RANKS:} A CRITICAL "CHANGE OF SITUATION" IN CHINA

By 1895, this consensus at the center had lost any impact as an impetus for reform that it would have had during the period of individual efforts, which

${ }^{28)}$ Hsü, The Rise of Modern China, p. 437. It should be noted that all of the memorials were addressed to the Imperial Censorate, which had the option to pass them on to the throne. In the case of the "Petition from the degree candidates", the Censorate had chosen not to exercise their option; they did exercise this option on Kang's next memorial.

${ }^{282}$ Hsü, The Rise of Modern China, p. 437. This was the third memorial that K'ang had sent. In addition to the "Petition from the degree candidates" at the metropolitan examinations, he had also been unsuccessful in an earlier attempt to present a memorial to the young Kuang-hsü emperor in 1888, when K'ang had held only the sheng-yüan degree. For a discussion on the place of the 1888 memorial in the ching-i movement, see John Schrecker, "The Reform Movement of 1898 and the Ch'ing-i," in Cohen and Schrecker, Reform in Nineteenth-Century China, p. 295. There was a fourth memorial submitted by K'ang on representative government, which was also prevented from reaching the throne by the Censorate. See Chesneaux et al., China From the Opium War to the 1911 Revolution, p. 309. Although one possible reason for the success of the third memorial was that K'ang had finally become a member of the "bureaucratic establishment", this would not account for the failure of his fourth memorial. Since the second and the fourth memorials advocated political changes, the reason for their failure to reach the throne may have been related to their content. 
collectively have been called the Self-Strengthening Movement. ${ }^{283}$ Trends had emerged which served to negate the impact of a central consensus. As previously mentioned, the pace of educational reform had already begun to accelerate in the 1890s. ${ }^{284}$ At the same time, a new generation of Chinese scholars were maturing in an intellectual climate that had already been affected by a shift in its foundation. The evidence of this shift was their "intellectual" appetite for Western learning, which Liang Ch'i-ch'ao later described. ${ }^{285}$ A third trend was the fact that "reformism" was no longer confined to a few political centers identified with individual reformers, such as Tientsin, Nanking, and Wuhan, but was spreading throughout urban China through the developments of "study societies" (hsüeh-hui) and of reform journalism. In September of 1895, all of these trends were united in the formation of the Society for the Study of Strength (Ch'iang-hsüeh-hui ) ${ }^{286}$ in Peking and the October founding of a branch in Shanghai, which initiated a pattern that spread across the urban face of China, where local study societies were formed to focus attention on the issue of educational reforms.

Although he may not have originated the idea of a study group of reformminded intellectuals, such as the Society for the Study of Strength, K'ang Yu-

${ }^{283}$ Marianne Bastid argues against the concept of a unified reform movement and has limited the Self-Strengthening efforts to the 1860-1885 "strategy" of Tseng Kuo-fan and Li Hung-chang. See her Educational Reform in Early Twentieth-Century China, pp. 11-12. Luke Kwong argues that to consider the individual innovations a "movement" distorts the reality that they were never a "bona fide" movement and has resulted in the historical verdict of "failure" usually given to the Self-Strengthening "Movement". See Luke S.K. Kwong, A Mosaic of The Hundred Days: Personalities, Politics, and Ideas of 1898 (Cambridge: Hanvard University Press, 1984), p. 152.

${ }^{284}$ An example of this acceleration is indicated by the dates of K'ang Yu-wei's memorials. While seven years had passed between his first attempt in 1888 and the "Petition from the degree candidates" of May 2, 1895, K'ang's third and fourth memorials were presented within two months of the second (on May 29 and June 30 of 1895).

${ }^{285}$ See quotation from Liang [p. 87]. Liang also wrote that these young intellectuals were "Scholars of New Learning of the Kuang-hsũ period (1875-1908), who were looking for knowledge from abroad..." See his Ching-tai hsüeh-shu kai-lun, p. 113.

${ }^{286}$ This group has also been referred to as the Society for the Study of National Strength (Kuo-ch'iang hui). 
wei immediately became a leader and spokesman for the group. ${ }^{287}$ The manifesto for this organization, attributed to K'ang Yu-wei, displayed a sophisticated assessment of China's position in the international political arena, which actually belied the negative assessment of a completely "unenlightened" Chinese intellectual climate. K'ang Yu-wei's words could also be considered an indication that some "enlightenment" had been part of his own education:

"The Russians are spying on us in the north and the English are peeping at us on the west; the French are staring at us in the south and the Japanese are watching us in the east. Living in the midst of these four strong neighbors, and being the Middle Kingdom, China is in imminent peril. How much more so will it be when there are more than ten nations who are sharpening their teeth and watering at the mouth, desiring to share the surplus?...[The manifesto then cites the current colonial or semicolonial status of India and Turkey as examples of the fate of conservative nations which did not respond to aggressive challenges by changing their traditions]...Our enfeebled China has been lying in the midst of a group of strong powers and soundly sleeping on the top of a pile of kindling. In administration she cares only to prevent evils but does not care to develop sources of profit. Her officials know only how to be law-abiding, but do not know how to judge the trends of the time. Her scholars specialize in the study of antiquity, but not in understanding the present. Her people can defend their immediate surroundings but cannot go far afield....Westerners are very strict about races and they look upon other races as enemies. When the French obtained Annam, the way for the Annamese to become rich and ennobled through the civil service examinations was cut off and the former prominent officials have now become silk merchants. England conquered India more than a hundred years ago, but it was not until 1889 that an Indian was elected a member of Parliament....For China, on the great earth, has had a ceaseless succession of sacred emperors and the country has been very famous....The vastness of her

${ }^{287}$ The founding of the society (in July of 1895) has been attributed to Wen T'ing-shih, an associate of the Grand Councilor and former Imperial Tutor, Weng T'ung-ho (1830-1904) in Chesneaux, et. al., China From the Opium Wars to the 1911 Revolution, p. 310. John Schrecker presents the following developments: Wen became acquainted with K'ang Yu-wei in 1888; under Weng T'ung-ho's patronage, both Wen and Chang Chien were associated with the "Pure Flow Party" in 1894 Peking; and in 1895, Wen held informal discussions for the young degree candidates in the capital, and K'ang founded the Society for the Study of Strength from these meetings. Schrecker has connected all three of these events to the ch'ing-imovement, directed against Li Hung-chang's policies. See John Schrecker, "The Reform Movement of 1898 and the Ch'ing-i," in Cohen and Schrecker, Reform in Nineteenth-Century China, pp. 294-96. Both Grieder and Hsü attribute the founding of the society to K'ang Yu-wei. 
territory is ranked third among the myriad states, the number of her people is rated the first; her climate is in the temperate zone, her people are intelligent and accomplished, and her soil is rich and productive. Among all countries on earth none is her equal. Only because her customs are unenlightened and because of a dearth of men of ability, she is passively taking aggression and insult. [Tseng Kuo-fan's efforts in training militia during the Taiping Rebellion and the development of a Prussian society to strengthen that country for the FrancoPrussian War are then cited as examples of successful reforms in the face of aggression]... In Japan there were people who advocated respect for the Emperor and the rejection of the barbarians and hence they accomplished their reforms. Generally, knowledge can be achieved by means of discussion and men of ability can be produced by encouragement. When the talent and power of many people are combined, then it is easy to assemble the books; and when the minds and thinking of the people are combined, then it is easy to exchange information. [The manifesto then quotes the Classic of Changes and the Analects on the importance of scholarly discussions]... All you gentlemen, how can you avoid the grief of being ruined and subject to the rule of a different race? Are we trying to avoid slander? O you closed door scholars, are some of you coming to the point of speaking about respecting the emperor and rejecting the barbarians? If you do, not only the teachings of the sacred Ch'ing dynasty, the two emperors, the three kings, and Confucius, but also the four hundred millions of the people will have something to rely upon." ${ }^{288}$

These words clearly reflected the influence of K'ang's earlier self-directed study in the 1880s, when he had read "histories and travelogues" and had "studied new ideas in China and the West" and "pored over maps of the world". ${ }^{289}$ At the same time, the thought behind this manifesto demonstrated a mastery of the traditional education that had enabled him to gain the chin-shih degree.

The importance of the manifesto was not that it presented radical new,

${ }^{288}$ Excerpted from the translation in Teng and Fairbank, China's Response to the West, pp. 152-53. The underlining is mine for emphasis. "Respecting the emperor and rejecting the barbarians" was a phrase associated with the successful Japanese reformers, who helped to bring about the Meiji Restoration in 1868.

${ }^{289}$ See the excerpts from K'ang's autobiography on page 97. 
intellectual concepts ${ }^{290}$ but that it represented a synthesis of both traditional Chinese and nontraditional Western educational influences in one scholarly discussion of China's current situation. Although earlier scholarly writers (such as Hsüeh Fu-ch'eng or Yen Fu) had introduced Western concepts, their writings took a more comparative approach in their effort to stress the differences between Chinese and Western intellectual traditions. ${ }^{291}$

Although the Peking Society for the Study of Strength was forced to disband after only a few months ${ }^{292}$, this organization represented a significant step in the Chinese reform process. This was the first time that elite bureaucrats and young degree-holders had joined in an effort to discuss and promote reforms. Among the elite official members were: Chang Chih-tung; Yüan Shihk'ai; Weng T'ung-ho; another Grand Councilor, Sun Chia-nai; and the Governor of Hunan, Ch'en Pao-chen. Upon its founding, both Chang and Li Hung-chang had offered donations to the group. ${ }^{293}$ In addition to K'ang, younger members included Wen T'ing-shih, Chang Chien (Shanghai), and Liang Ch'i-ch'ao, who

${ }^{290}$ Schrecker connected the ideas of K'ang's "manifesto" to the ch'ing-i tradition and concluded that they could have been written by the conservative Imperial Censor, Wo-jen. See his essay, "The Reform Movement of 1898 and the Ch'ing-i," p. 297. Sung Wook Shin characterized the Society for the Study of Strength as a "new vehicle of the self-strengthening movement," in his essay, "Reform Through Study Societies in the Late Ch'ing Period, 18951900: The Nan Hsüeh-hui," p. 310. Both essays are in Cohen and Schrecker, Reform in Nineteenth-Century China.

${ }^{291}$ One can certainly argue that Wang T'ao and Cheng Kuan-ying had also approached Chinese problems and world affairs by a synthesis of both intellectual traditions. However, both of these men were representative of the 'treaty port' intellectuals; therefore, their writings were outside of the Chinese scholarly tradition.

${ }^{292}$ In November of 1895, a marriage relative of Li Hung-chang, Yang Chung-i, wrote an official censorship of the group, accusing it of subversive activities. The Peking Society for the Study of Strength was forced to disband and became the "Book Depot to Strengthen Learning" in November. See John Schrecker's description of the political maneuverings which surrounded the Peking branch of the organization in "The Reform Movement of 1898 and the Ch'ing-i," in Cohen and Schrecker, Reform in Nineteenth-Century China, pp. 297-98. On the accusation of "subversive" activities, see Chesneaux, et al., China From the Opium Wars to the 1911 Revolution, p. 310. Immanuel Hsü gives the official date of dissolution as January 21,1896, in The Rise of Modern China, p. 438.

${ }^{293}$ Schrecker notes that Li's donation was "pointedly refused" in his "The Reform Movement of 1898 and the Ch'ing-i," in Cohen and Schrecker, Reform in Nineteenth-Century China, p. 297. Ayers lists Chang's contribution as 5,000 Taels to the Peking group in Chang Chih-tung and Educational Reform, p. 141. 
became one of the secretaries of the Peking group. In October of 1895, a branch of the Society for the Study of Strength was established in Shanghai by K'ang Yu-wei, who had left the capital after an internal dispute within the original group. Liang remained in Peking, where he worked with the reorganized Book Depot to Strengthen Learning (Ch'iang-hsüeh shu-chü), which was intended to be an education and publication bureau on reform. Many members of this new organization came from the ranks of the Hanlin Academy. ${ }^{294}$

The founding of this study society represented more than the initial attempt of Chinese intellectuals to unite in a reform effort. It set precedents that would rapidly change the intellectual climate of the country. By attracting the interest of Westerners, the society established the basis for a new relationship (education and reform) between Chinese officials as a class and progressive missionaries. ${ }^{295}$ In particular, Timothy Richard expressed interest and kept in close touch with Liang Ch'i-ch'ao, to whom he offered advice and articles on Westernization and reform from the S.D.K. publication, Review of the Times, for republication in the society's daily news sheet, the Ch'iang-hsüeh-pao. ${ }^{296}$ This publication, which reached a daily printing run of 3000 , represented an even

\footnotetext{
${ }^{294}$ By December, 1895, the "Book Depot" occupied more than forty rooms in southern Peking. Ambitious projects for translations and new Chinese works on current affairs were scheduled, but these efforts were stopped by the court decree of dissolution in January. See Kwong, A Mosaic of the Hundred Days, pp. 95-97.
}

${ }^{295}$ Robert Scalapino and George $Y u$ indicated that the relationship between the missionaries, Timothy Richard and Gilbert Reid, and the Ch'iang-hsüeh-hui (the "Reform Club" is their translation) was an "intimate association". See their Modern China and Its Revolutionary Process, p. 66. For the previous missionary efforts to establish a "common ground" with the Chinese elite, as a group, see pp. 59-60 (Chapter 2). Of course, there had been interactions between Chinese officials and missionaries on an individual basis; see the previous examples of medical missionaries [pp. 60-63, Chapter 2] and Chang Chih-tung's connection to Timothy Richard [footnote 212, Chapter 2].

${ }^{296}$ The society's one-page newspaper was originally titled Wan-kuo kung-pao, as a tribute to the S.D.K. publication, but the name was changed when it was moved to Shanghai. Richard and Liang maintained a close correspondence. See Ayers, Chang Chih-tung and Educational Reform, p.140; and Hsü, The Rise of Modern China, p. 437. Robert Scalapino and George Yu attributed the original titling of the paper and the extensive republishing of missionary articles to the Chinese reformers attempts to "avoid official repression". See their book, Modern China and Its Revolutionary Process, p. 81. 
more significant alteration of Chinese society. For the first time, the reform effort moved out of the traditional context (private discussion groups and official memorials) and was presented in a new forum, the "public" newspaper. ${ }^{297}$ For the young writer and editor, Liang Ch'i-ch'ao, his work on the "Society for the Study of Strength" Newspaper helped to establish his reputation as a modern Chinese journalist. ${ }^{298}$

With the disbanding of the first study society, many of the original members carried on the spirit of the new reform era by turning their efforts to founding study societies throughout urban China in the next few years. ${ }^{299}$ However, there was one difference between the Society for the Study of Strength and many of these later associations; that difference was the radicalization of reform programs. ${ }^{300}$

${ }^{297}$ The term "public" refers to the fact that the publication was mass produced and intended for general distribution among those members of bureaucracy and the gentry who were literate. Hao Chang considers these new experiments in reform publications of great significance to the Chinese intellectual scene and the entire reform movement of the 1890s. See his Liang Ch'ich'ao and Intellectual Transition in China: 1890-1907 (Cambridge: Harvard University Press, 1971), pp. 5-6. Also see Kwong, A Mosaic of the Hundred Days, p. 153.

${ }^{298}$ See Philip C. Huang, Liang Ch'i-ch'ao and Modern Chinese Liberalism (Seattle: University of Washington Press, 1972), pp. 24-25. He gives the name of the publication as Chung-wai kung-pao (International Gazette), which would have been a logical title. The literal translation is The Chinese and Foreign Gazette. The only "competition" in Peking was the Ching-pao (Peking Gazette). Scalapino and Yu noted that the International Gazette was printed with the same wooden block method as the Peking Gazette and probably profited from its similarity in appearance to the official publication. See their Modern China and Its Revolutionary Process, p. 81.

${ }^{299}$ The locations and English names for some of the more significant associations are: Chihli, Society for the Study of the West; Shanghai, the Agronomy Society, the Medical Benevolence Society, and the Society for Translating Books; Hupeh, the Essential Study Society; Kwangsi, the Society for the Study of the Sage; Shensi, the Society of Effort; and Hunan, the Southern Study Society. All of these were founded in 1897. See Chesneaux et. al, China From the Opium Wars to the 1911 Revolution, p. 310. Study societies would continue to play an important role in revolutionary China, after 1911. Arif Dirlik has done a study of the role that they played during the New Culture and May Fourth Era (1915-1922) in the radicalization of students and the spread of anarchism and Marxism in his book, The Origins of Chinese Communism (New York: Oxford University Press, 1989), pp. 11-15, 157-90. Mao, Chou En-lai, Liu Shao-ch'i, and Teng Hsiaop'ing had all belonged to study societies in their home provinces.

${ }^{300}$ See Sung Wook Shin's discussion of the radicalization of the Southern Study Society in his essay, "Reform Through Study Societies in the Late Ch'ing Period," in Cohen and Schrecker, Reform in Nineteenth-Century China, pp. 310-12. 
At least three factors assisted in this trend toward radicalization. The first was the shift of power (in this case, organizational power) from the center to the provinces and this paralleled the earlier individual successes during the SelfStrengthening Movement. As previously discussed, reform innovation at the provincial level was much less politically risky than similar efforts at the center. The fate of the Society for the Study of Strength testified to the potential risks associated with reform efforts at the political center.

Related to this shift of reform activities to the provinces was the increasing preoccupation of the center with national and international problems (nei luan wai huan). In late 1895, Sun Yat-sen had attempted to mount his first revolutionary effort against the Manchus in Canton, and was forced to flee the country with a price on his head. The Ch'ing government continued to be concerned with the Treaty of Shimonoseki, as they negotiated foreign loans to pay the $230,000,000$ Taels indemnity to Japan. There was a continuing Moslem rebellion in the West and a secret society (Big Swords) uprising in the East. Germany began their aggressive military movements into Shantung province, with the intention of establishing their own sphere of influence. The government in Peking and the regional "Viceroys" had once again become pressured by this newest phase of "internal chaos and external troubles" in the last years of the nineteenth century; and this preoccupation allowed provincial reform efforts to develop virtually unchecked. ${ }^{301}$

The third factor was a product of the shift that was occurring in the intellectual foundations. By the 1890s, the officials who have been identified as members of the first group of reformers had risen to positions in the Ch'ing government where they were directly involved in coping with the national situations presented above. These affairs left them little time for directing the reform efforts within their regions, as they had been able to do in the 1880 s. Therefore, in the significant years between 1895 and 1898, when an attitude of reformism was sweeping the country, local activities became less subject to the

\footnotetext{
${ }^{301}$ During the years, 1896 and 1897, China negotiated and signed treaties with Russia, Britain, and Japan and separate commercial agreements with Danish, English, French, and German concerns for railroad and telegraph construction. For a detailed listing of these activities in 1896-97, see Mackerras, Modern China, pp. 180-87.
} 
direct supervision of the older, more powerful, elite reformers than they had been in the past.

Traditionally, scholar-bureaucrats began their careers with appointments at the local or provincial levels of government. These new officials were the first group of young men who had been exposed to Western influences, at least indirectly, throughout their entire educational period. When they were presented with a first-hand experience of how an Asian nation with a Confucian-influenced tradition could modernize in China's defeat at the hands of Japan, it seemed only logical that this generation might begin to question previous attempts to modernize their own traditions. When K'ang Yu-wei had called attention to the need for educational reform in 1895 and the first study society was welcomed by officials high and low, it appeared that a consensus had developed between the first and the second transitional generations that the initial Chinese "institution" to be reformed [pien-fa] was the educational tradition. The emphasis was no longer to be on selected adaptation of Western techniques ( $\mathrm{Hsi}-\mathrm{I})$ but on general incorporation of Western learning (Hsi-hsüeh) into the educational foundation. ${ }^{302}$ When this tentative consensus was shattered by political maneuvering, a logical conclusion among the younger generation could have been that true educational reform would remain impossible without concurrent political reforms. Perhaps a better definition of the alteration of reforms in the late 1890 s should refer to its politicization, rather than its radicalization. ${ }^{303}$

The changes in the reform process in the years immediately after the Sino-Japanese War were also reflections of fundamental alternations in the

${ }^{302}$ Marianne Bastid has termed this a shift of emphasis on the part of the K'ang Yu-wei's group from a change of things (pien-shih) to a change of methods or structure (pien-fa). See her book, Educational Reformer in Early Twentieth-Century China, p.7. This would coincide with Grieder's second stage of reforms at the time of the Sino-Japanese War, which he also identified as a pienfa. See Grieder's work, Intellectuals and the State in Modern China, p. 79; and the previous discussion in the Introduction.

${ }^{303}$ Education had always had a link to politics in Chinese tradition, as a method of political indoctrination and as the only "institutionalized" method of training civil servants. Refer to the discussion of this historical link in the Introduction. The change in the period of 1895-98 refers to the shift in attitude, characterized as a revolution (ko-ming) by Grieder, Intellectuals and the State in Modern China, p. 79. For other perspectives of this combined political-intellectual shift, see Marianne Bastid, "Servitude or Liberation?," in Hayhoe and Bastid, China's Education and the Industrialized World, p. 9; and Chang, Chinese Intellectuals in Crisis, p. 5. 
entire intellectual climate of the country. Whereas the first generation's activities were characterized by "individual" interests in specific applications, those of the second arose out of an overwhelming "collective" interest in general reformism. One indication of this change was the accelerated rate at which information became available. These were the years in which Yen Fu began publishing his translations of Western works. Among the missionary translations published by the S.D.K, there was a change not only in the number of translated works but also in the content of those translations. The Society's secretary, Timothy Richard, wrote four books which had definite reform content and arranged for the translation and publication of a fifth work, Robert MacKenzie's Nineteenth Century, A History, which became so popular that it had to be reissued. ${ }^{304}$ At the same time, John Fryer wrote and published Some Advice on How to Rule (Tso-chih ch'u-yen), before he left China in 1896.

Chinese reformers were also involved in the dissemination of information and opinions. In 1896, Liang Ch'i-ch'ao published his Hsi-hsüeh shu-mu-piao ( $A$ bibliography of western learning); and between 1896 and 1898, twenty-five new journals began publication. ${ }^{305}$ The first of these was the Shanghai Society for the Study of Strength Newspaper, and this was succeeded at the end of 1896 by another influential Shanghai reform periodical, Contemporary Affairs (Shih-wu pao), which was launched through the efforts of Wang K'ang-nian, with Liang Ch'i-ch'ao as editor. Since Chang Chih-tung was a patron of Wang and had contributed to the periodical's foundation, he ordered that the Contemporary Affairs be distributed among officials in the province of Hupeh, which was part of Chang's jurisdiction. ${ }^{306}$ The format that eventually evolved

${ }^{304}$ The dates and English titles of Richard's works were: 1895, An Account of the Reforms and Revivals of Various Countries; 1896, New Policies; and 1899, The Warning Bell from the West and Four Chinese and Western Major Policies. The Chinese titles are also given in Ch'ên, China and the West, p. 117. Ch'ên writes that MacKenzie's work was a "scientific" history and, although inferior to Yen Fu's work, it eventually reached a publication total of almost one million copies; see China and the West, pp. 69, 117. Immanuel Hsü has characterized Richard's works as promoting his interest in "institutional" reforms; see his The Rise of Modern China, p. 426.

${ }^{305}$ See Chesneaux et al., China From the Opium Wars to the 1911 Revolution, p. 310.

${ }^{306}$ On Chang Chih-tung's early association with the paper, see Ayers, Chang Chih-tung and Educational Reform, pp. 138-40. 
was that of a journal of thirty pages, issued every ten days, and circulated throughout China, with printing runs of more that 10,000 copies. ${ }^{307}$ It was within this journal format that Yen Fu's reform ideas presented in his 1895 Tientsin essays were popularized throughout the country by Liang Ch'i-ch'ao. It was also in the Contemporary Affairs that Liang published a series of ten essays under the general title, "A General Discussion of Reform" (Pien-fa t'ung-I), in which his writing displayed an integration of classical knowledge with Western learning. In the preface, Liang's developing journalistic writing style and his Classical education were evident:

"Why is it necessary to reform? In general, there is nothing in the universe which does not change....Throughout the span of one thousand years there was not a single time without change, and not a single thing without change....Those who advocate no change frequently claim, 'We follow the ancients, follow the ancients.' Do they know that from prehistoric, ancient, medieval and modern times down to the present day, there have been hundreds of thousands and myriads of changes?...The Book of Changes says, 'When there is exhaustion, there should be change; after a change there is cohesion; when there is cohesion things will be long-lasting.' "' "308

In these phrases, Liang presented a "natural" argument for change ("there is nothing in the universe which does not change") and described historical periodization in a decidedly nontraditional manner ("prehistoric, ancient, medieval and modern"), which showed Western influence. Liang's "natural" argument amended to and updated Hsüeh Fu-ch'eng's "historical" argument for change in the 1880s. ${ }^{309}$ Although he did not mention the previous work, there appeared to be a definite connection between the two arguments; in fact, Hsüeh Fu-ch'eng's ideas had gained a new, more receptive, audience, when his complete works were published three years after his death in 1894 .

Among Hsüeh's many observations on the Chinese tradition which

${ }^{307}$ Scalapino and Yu, Modern China and Its Revolutionany Process, pp. 81-82.

${ }^{308}$ Excerpt from the translation in Teng and Fairbank, China's Response to the West, pp. 15455.

${ }^{309}$ See the previous discussion of Hsüeh's historical pattern of change on pages 73-5 [Chapter 2]. 
interested the young reformers was his conclusion that the examination system had "led hundreds of thousands, even millions, of scholars to exhaust their physical and mental energies over formal literary exercises without ever studying the art of governing or the laws of history." interest in his essay, "On Reform", with the positive message advocating the study of Western methods, because "we must have a thorough knowledge of their methods before we can change, and only after changing can we surpass them. ."311

In his article on education in the "A General Discussion of Reform", Liang also addressed the issue that the examination tradition had become an obstacle to the modernization of education. Although his words sounded familiar, his argument was more straightforward:

"...[T]he basis of reform lies in the cultivation and development of talent; the flourishing of talent depends on the setting-up of schools; the establishment and success of schools depend on changing the examination system; and the substance and success of all this lie in reforming the official system.... If the nation wishes to strengthen itself, then this matter [the setting up of modern schools] is the most important matter." ${ }^{312}$

However, having presented what could be considered the traditional reformist argument against the system, Liang's assessment of those "products of this system" who continued to resist the needed changes was unconventionally frank:

"The reason why the conservative party obstructs institutional reform is not really because they see harm to the state or the people in the new laws. If the eight-legged essay is the means by which I passed the civil service examinations, but now suddenly practical studies are [to] be pursued, then my road to personal

\footnotetext{
${ }^{310}$ Bastid, Educational Reformer in Early Twentieth-Century China, p. 11.This same argument that traditional education had ruined the physical health of young scholars became one of the main themes in the articles written for the radical journals of the Chinese students who were studying in Japan in the early twentieth century. See the excellent article on these students by Robert A. Scalapino, "A Prelude To Marxism: The Chinese Student Movement in Japan, 19001910," in Feuerwerker, et al., Approaches to Modern Chinese History, pp. 190-215.

${ }^{311}$ See the previous citations and the discussion of this essay on pp. 73-6 [ Chapter 2]. The underlining is mine for emphasis here.
}

${ }^{312}$ Huang, Liang Ch'i-ch'ao and Modern Chinese Liberalism, p. 30. 
advancement is going to be cut off. If I have depended upon conventional credentials to attain high office, but now suddenly appointments are to be based on ability, then the things that brought me vainglory will vanish....If suddenly one day there is institutional reform, all those holding office will be required to manage affairs. Will I obey the order and manage affairs? Since I lack both learning and ability, and energy besides, how can I do so?..."313

As the individual assessment of one young scholar, this sarcasm might have been considered a typical expression of jealousy on the part of one who had not yet been able to gain status through the system. ${ }^{314}$ However, the fact that it was presented in the "public" forum created by the Contemporary Affairs national circulation must have intensified the consternation that the elite targets felt.

In addition to calling for reform and attacking the examination system, Liang also addressed the vital cultural question of language in his reform essays. The question of reforms had hitherto been confined to elite education, but Liang presented a more radical idea:

"The written language of the ancients corresponded to their spoken language.

But the written language today is different from the spoken language.....If we only use the colloquial language of today...then there will necessarily be many who can understand and the number of literate people will accordingly increase....We should use only the colloquial language today and write plenty of books." ${ }^{.15}$

This conception that education should benefit all the people was a definite departure from the traditional norm that language should act as a social barrier in order to separate the "superior man" from the common man.

Although Liang Ch'i-ch'ao must certainly be considered an extraordinary individual, his essays in the Contemporary Affairs did not represent the novel

\footnotetext{
${ }^{313}$ Gentzler, Changing China, pp. 87-88.

${ }^{314}$ In 1896, Liang was only twenty-three years old and had failed to gain an official appointment when he did not pass chin-shihexamination in 1895.

${ }^{315}$ Huang, Liang Ch'i-ch'ao and Modern Chinese Liberalism, pp. 30-31. This promotion of "colloquial" language anticipated the "literary revolution" during the New Culture era, when writers and scholars began to use "plain speech"(pai-hua) in their work. In his discussion of this literary revolution, Chow Tse-tsung refers to these essays by Liang Ch'i-ch'ao as an example of the "embryonic ideas for literary reform" that were developed at this time. See his The May Fourth Movement, pp. 270-71.
} 
ideas of one angry young man. They were merely some of the better-written examples of opinions representative of an entire generation of angry young men. In that same year of 1897, the first Chinese owned publishing house, the Commercial Press (Shang-wu yin-shu-kuan), was established in Shanghai; Yen Fu helped to found the National Review (Kuo-wen pao), a daily paper in Tientsin; and the reform journal, Kiangsu Tribune (Su-pao), began publication in Shanghai. ${ }^{316}$ This brief survey is an example of what can only be described as a "publishing" revolution that developed in conjunction with the intellectual revolution that was occurring in the last years of the nineteenth century in China.

In addition to these activities in Chihli province (in Tientsin) and in the lower Yangtze (Chekiang, Kiangsu, and Shanghai), there were two other major reform areas. One was in another coastal province, long affected by interactions with Westerners, Kwangtung, which had been the sight of the first abortive revolutionary endeavor of Sun Yat-sen in 1895 and was the home of K'ang Yuwei's school. The fourth reform center, Hunan, which formed part of the Hukwang jurisdiction of Chang Chih-tung, was different. As an inland province, Hunan had largely escaped prolonged contact with Westerners; and, because of the damage and dislocation caused by the radical Taipings, the gentry had tended to be more conservative. ${ }^{317}$

${ }^{316}$ Mackerras, Modern China , p. 187. The Kiangsu Tribune subsequently became radically revolutionary in orientation with a call for the overthrow of the Manchus in 1903, was eventually closed, and was the subject of a lengthy and spectacular trial in Shanghai. Mary Backus Rankin has done a detailed study of these developments and their association with the earlier reform efforts in her book, Early Chinese Revolutionaries (Cambridge: Harvard University Press, 1974), pp. 48-95.

\footnotetext{
${ }^{317}$ Hankow, one of the Wuhan cities, had been opened as a treaty port in 1861 , but its inland position and the Taiping Rebellion had delayed its development. For the conservative intellectual climate, see Chesneaux, et al., China From the Opium Wars to the 1911 Revolution, pp. 311-12. The authors make the point that the elite were mainly traditional scholars and that the reformers adopted more radical ideology in response to that conservatism. It should be noted that Hunan had a reputation for scholarship, and that it was quite probable that the disruption of the Taiping Rebellion had reinforced the position of traditional education in the decades that followed, in order to regain Hunan's scholarly status in the examinations. Hunan was also the home province of both Mao Tse-tung and Liu Shao-ch'i, both of whom were considered leading Chinese Communist Party ideologues.
} 


\section{A GATHERING OF "MEN OF TALENT" IN HUNAN PROVINCE: THE POLITICIZATION OF EDUCATIONAL REFORMS}

In this conservative atmosphere, when a union of scholars and civil servants from outside the province and the local gentry ${ }^{318}$ occurred in the founding of the Southern Study Society (Nan hsüeh-hul), subsequent activities resulted in what could be considered the beginning of a "social revolution". The background for this "social revolution" was the climate for reform created in Hunan province by the governor, Ch'en Pao-chen, who had been one of the initial supporters of the Society for the Study of Strength in Peking and a progressive force for Self-Strengthening at the provincial level. ${ }^{319}$

After the failure of the Peking study society, Ch'en concentrated his efforts in his own province, gathering a group of young civil servants, Huang Tsunhsien and Chiang Piao, and gentry members, T'an Ssu-t'ung (1864-1898) and T'ang Ts'ai-chang ${ }^{320}$, to develop a reform program. In the field of education, the provincial director, Chiang Piao, made several reforms, including: the introduction of materials from the S.D.K. in selected curricula; the establishment of the Academy to collate the classics (Chiao-ching shu-yüan) in Changsha as

\footnotetext{
${ }^{318}$ See the previous footnote [299] on the foundation of provincial and local study societies. The "gentry" were those local, urban, and/or regional leaders, who were not members of the regular civil-service official elite. These leaders gained their power and influence through landed wealth, commercial activities, and/or the new industrial enterprises. Sometimes, local scholarteachers, who usually had not progressed through the examination structure beyond the shengyüan(district) level, were also considered members of the local educational gentry.

${ }^{319}$ On Ch'en's support of Self-Strengthening, see Scalapino and Yu, Modern China and Its Revolutionary Process, p. 81.

${ }^{320}$ Ayers uses these designations. Huang was a close associate of Chang Chih-tung, who was responsible for his appointment as Hunan judicial commissioner. Chiang was the provincial education director. T'an and T'ang were local scholars, who were associated with the educational gentry. T'ang was executed in 1900 on Chang's orders, after his abortive attempt to begin a revolution against the Manchus. See Ayers, Chang Chih-tung and Educational Reform, pp. 140, 144; and Chang, Liang Ch'i-ch'ao and the Intellectual Transition in China, pp. 123-24. The son of the governor of Hupeh, T'an Ssu-t'ung became a part of the K'ang-Liang reform effort and was executed in Peking in the aftermath of the Hundred Days Reform in 1898, as one of the Six Martyrs.
} 
a "center for Western learning and educational experiences"; the addition of geography and mathematics as topics in the sheng-yüan degree; and the organization of the Southern Study Society. ${ }^{321}$ The society's stated goal was "min-chih" (popular enlightenment) and their methods were: a public lecture series (kung-chiang-i); a public library (ts'ang-shu ch'u or Bureau of Book Collection); the promotion of public education (hsüeh-t'ang or local public schools); and a four-page daily newspaper, the New Journal of Hunan Studies (Hsiang-hsüeh hsin-pao), which began as a moderate reform publication and only assumed more radical overtones under the editorship of T'an Ssu-t'ung in late 1897. ${ }^{322}$ The significance in each of these methods was that they were intended to foster a new "spirit of public interest" (kung-i wei chu-i) among all the people of Hunan, which could then establish "the beginning of equality for other provinces." ${ }^{323}$ The subject matter in the New Journal of Hunan Studies included the usual editorials, reports on matters of national significance, such as treaties, and translations of Western works found in most of these reform journals in 1896-97. However, the paper also reflected the changing political and intellectual climate of the province, with political assessments of local affairs, membership discussion forums, and letters from the reading public. ${ }^{324}$

${ }^{321}$ This society was also known by the name of Hunan study society (Hsiang-hsüeh hui).

${ }^{322}$ For a detailed account of the entire program of the Southern Study Society, see Sung Wook Shin, "Reform Through Study Societies in the Late Ch'ing Period," in Cohen and Schrecker, Reform in Nineteenth-Century China, pp. 310-16. On the radicalization of the newspaper, see Esherick, Reform and Revolution in China, p. 13; and Scalapino and Yu, Modern China and Its Revolutionary Process, p. 81. Esherick notes that upon the dissolution of the society in 1900, other groups were formed with more specific agenda, such as marriage reform, ceremonial reform, women's liberation, and the eradication of foot-binding. These early (1900) reform themes indicate that young members of study societies had already begun to question the "basic social norms" of their tradition. See Esherick, Reform and Revolution in China, pp. 15-16. This anticipated the "cultural revolution" that is associated with the New Culture Movement and the May Fourth Movement, begun some fifteen years later, in 1915-17.

${ }^{323}$ From the speech of one of the members, P'i Hsi-jui, at a lecture meeting, in Shin, "Reform Through Study Societies in the Late Ch'ing Period," in Cohen and Schrecker, Reform in Nineteenth-Century China, pp. 311.

${ }^{324}$ Shin, "Reform Through Study Societies in the Late Ch'ing Period," p. 312. Shin notes that, although no circulation records survive, it is known that the paper was distributed at the village level. 
One of the most important educational reforms in Hunan, which became connected to the Southern Study Society through the membership of its faculty, was Chiang Piao's founding of the School of Current Affairs (Shih-wu hsüeht'ang) in the capital of Hunan, Changsha, with the support of the Hunan gentry in $1897 .{ }^{325}$ However, before the school was opened, the more moderate Chiang had been replaced by a young reformer and friend of T'an Ssu-t'ung, Hsu Jenchu. It was this new education director who approved the recommendation by Huang Tsun-hsien that a rising young scholar, Liang Ch'i-ch'ao, should be invited to Hunan and to join the faculty of the School of Current Affairs, as the lecturer in Chinese studies. ${ }^{326}$ Liang was also acquainted with another faculty member, T'an Ssu-t'ung, whom he had met in Peking in 1895. ${ }^{327}$

The School of Current Affairs had a faculty of eight and a resident study body of forty young men between the ages of fourteen and twenty, who had been selected from the four thousand who had taken the examination for entrance. ${ }^{328}$ From the beginning, the instruction was radical. Liang recorded that he spoke on "the political authority of the people" and "representative

${ }^{325}$ Chang, Liang Ch'i-ch'ao and the Intellectual Transition in China, pp. 124-25. Faculty members who were also significant in the study society were: Tan Ssu-t'ung, who was lecturer at the school; the director, Hsiung Hsi-ling; T'ang Ts'ai-ch'ang, an assistant lecturer; and later, Liang Ch'i-ch'ao, the chief lecturer in Chinese studies.

${ }^{326}$ Joseph Esherick has attributed both the replacement of Chiang with the younger Hsu and the later appointment of Liang to Huang Tsun-hsien. Huang, a native of Kwangtung, was a friend of Liang's and an acquaintance of K'ang Yu-wei. Esherick has termed these friends and followers of the "K'ang-Liang group" the "Cantonese" faction. If these events were actually connected through the actions of Huang, as Esherick has described them, then this deliberate maneuvering would confirm the politicization of the reform movement in Hunan. See Esherick, Reform and Revolution in China, p. 14. The ages of these men in 1897 were: Huang Tsun-hsien - 49; Hsu Jen-chu - 34; T'an Ssu-t'ung - 32; T'ang Ts'ai-ch'ang - 30; and Liang Ch'i-ch'ao - 24. The director of the School of Current Affairs was Hsiung Hsi-ling, who was only 27.

${ }^{327}$ Kwong, A Mosaic of the Hundred Days, p. 66. Kwong writes that T'an had traveled to Peking in the hope of meeting K'ang Yu-wei, who had already left for Canton. Instead of the teacher, T'an had met the student, Liang, and the two became friends.

${ }^{328}$ Wang notes the fact that the students were in residence allowed the radical content of the instruction to remain a secret until the students went home for their New Year's vacation in early 1898. See his Chinese Intellectuals and the West, pp. 235-36. Scalapino and Yu give the figure of entrance examinees in Modern China and lts Revolutionary Process, p. 81. The fact that so many young men attempted to gain entrance (4000 applicants for 40 positions) would be an indication of the popularity of the school. 
assemblies", and that "the atmosphere of the school became more radical day by day." 329 The readings that were required included: Mencius, the "New Text" (hsin-wen) doctrines of the Kung-yang school; Ming scholar-official Huang Tsung-hsi's $A$ plan for the prince (Ming-yi tai-fang $(u$ ); and an account of Manchu brutalities in 1645, the Ten day's sacking of Yang Chou (Yang-chou shih-jih chi). Liang recorded that the A plan for the prince was meant to instill "democratic" ideas in the students and the Ten day's sacking of Yang Chou was part of the moral diatribe against the Manchus. ${ }^{330}$

The young faculty based their commitment to teaching on the timehonored tradition that, as "superior men", they should serve the moral education of the people, a concept that was part of the Mencian school of Confucianism. ${ }^{331}$ Obviously, this concept would not have caused problems with the Confucian traditionalists among the education establishment, in Hunan or in Peking. It was their use of education to promote reform that caused their difficulties. That they were not unaware of possible conservative reactions to their programs was evident from an 1897 comment by T'an Ssu-t'ung: "To reform is to promote learning. Even if those in high places make no attempt at reform, they still cannot prevent learning from being promoted from below."332

In the spring of 1898, Liang Ch'i-ch'ao's association with the school came to an end, when he had to leave the faculty at the New Year's vacation-

${ }^{329}$ For Liang's comments on "political" subjects, see Huang, Liang Ch'i-ch'ao and Modern Chinese Liberalism, p. 26. For Liang's notation on the "radical atmosphere", see Esherick, Reform and Revolution in China, p. 16.

${ }^{330}$ See Chang, Liang Ch'i-ch'ao and Intellectual Transition in China, pp. 125-26; Esherick, Reform and Revolution in China, p. 16; Huang, Liang Ch'i-ch'ao and Modern Chinese Liberalism, p. 26; and Wang, Chinese Intellectuals and the West, p. 236. Naturally, both of the last two works had been banned by Ch'ing authorities.

${ }^{331}$ As noted, the Mencius was one of the required readings for the students. Mencius specified that the work of the "superior man" was the moral education of the youth in Book VII, Part I, Chapters, XXXII, XL. See Legge, The Works of Mencius, pp. 467-68, 473.

${ }^{332}$ Quoted in Luke S.K. Kwong, "Reflections on an Aspect of Modern China in Transition: T'an Ssu-t'ung (1865-1898) As a Reformer," in Cohen and Schrecker, Reform in Nineteenth-Century China," p. 192. 
break because of health reasons. ${ }^{333}$ However, in view of the storm of protest which arose among the Hunan gentry ${ }^{334}$ after their sons came home on break, there was every possibility the Liang would not have remained at the school, in any event. The battle lines ${ }^{335}$ that were eventually drawn, between the older, conservative parents and the younger, reformer-scholars of the faculty, eventually resulted in: the replacement of Ch'en Pao-ch'en by his more conservative lieutentant-governor, Yu Lian-san; the reorganization of the school as a traditional private academy, renamed the Academy of practical learning (Ch'iu-shih shu-yüan); the termination of the progressive faculty and expulsion of the more radical students; and the destruction of all the records related to the Southern Study Society, on the order of Chang Chih-tung. ${ }^{336}$

However, even though the conservatives were able to triumph in the matter of the School of Current Affairs, an educational precedent had been established. When the subject of modern schools became the topic of Imperial decrees in the development of a modern Chinese educational system in 19011902 , the pattern of the new schools would follow that of this institution: more students gathered together than had been the tradition in private academies; students became separated from more conservative, family influences with their residence in school dormitories; and a younger faculty with few ties to the traditional system were employed. ${ }^{337}$

${ }^{333}$ Huang, Liang Ch'i-ch'ao and Modern Chinese Liberalism, p. 26.

${ }^{334}$ Refer to footnote 317 for the conservatism of the traditional Hunan gentry.

${ }^{335}$ The "battle lines" included public posters ridiculing the young faculty members. See Esherick, Reform and Revolution in China, p. 18.

${ }^{336}$ Esherick, Reform and Revolution in China, pp. 17-18. Esherick makes the interesting observation that the destruction of the society's records "undoubtedly served to protect many gentry participants."

${ }^{337}$ Wang, Chinese Intellectuals and the West, p. 236. Wang also points out that the new faculty members frequently made the schools a "radicalizing" influence after 1902. Mary Rankin bases much of her discussion of radical influences on the new schools in Chekiang in Earty Chinese Revolutionaries. The tutors at the lower private schools were usually sheng-yüan, who had failed in the provincial (chü-jen) examinations; and the higher "schools" usually served as institutions of the examination system. See the discussion of traditional education, pp. 8-9 [Chapter 1]. 


\section{EDUCATIONAL REFORM MOVES TO CENTER STAGE: THE 1898 REFORM MOVEMENT AND THE EXHORTATION TO LEARN}

By the time that the School of Current Affairs was being reorganized into a more traditional academy, the arena for the reform movement had shifted back to Peking. K'ang Yu-wei, who had not been directly involved with the events in Hunan, continued his policy of direct memorialization to the throne that he begun with the 1888 memorial and carried through the summer of 1895 . When he had authored the "manifesto" of the Society for the Study of Strength, K'ang had specifically cited the successful example of reform under the Meiji Emperor in Japan in 1868, and had ended the document with what could be described as an early statement of his political ideology:

"...O you closed door scholars, are some of you coming to the point of speaking about respecting the emperor and rejecting the barbarians?"338

These words had been carefully chosen in 1895 for two reasons. The first was the obvious reference to the Japanese reform effort, which had just resulted in China's defeat in the War. The second reason was that by his repeated efforts to "open a channel of communication" (yen-lu) for reform dialogue with China's own young Emperor by means of his many memorials, K'ang was seeking to build a reform effort "from the top" around the Kuang-hsü Emperor. ${ }^{339}$ Among the many aspects of reform that he wished to discuss with the Emperor was a thorough "reform" of the traditional education structure.

By the early summer of 1898, K'ang had finally succeeded in establishing an open channel to the throne, and the Kuang-hsü Emperor issued

${ }^{330}$ See previous discussion and citation of the manifesto of the Society for the Study of Strength on pp. 111-13. Underlining is mine for emphasis.

${ }^{339}$ John Schrecker places the events of the Hundred Days Reform at the end of the longer ching-i movement, dating from the 1870's opposition to the bureaucratic establishment dominated by Li Hung-chang. He locates all of K'ang Yu-wei's memorials within this tradition. See his "The Reform Movement of 1898 and the Ch'ing-i," in Cohen and Schrecker, Reform in Nineteenth-Century China, pp. 294-302. The Kuang-hsū Emperor was twenty-seven at the time of the 1898 Reform Movement. Hao Chang has described the court situation as "a covert power struggle" between the Empress Dowager's "faction" and the young Emperor, who was growing "increasingly restive in his figure-head position." See Chang, Liang Ch'i-ch'ao and Intellectual Transition in China, pp. 129-30. 
his first reform decree on June $11,1898 .{ }^{340}$ One hundred and three days later (September 21, 1898), the Empress Dowager, reacting to the rumor that the K'ang Yu-wei reform group was plotting her assassination ${ }^{341}$, moved decisively to sequester the Emperor and to arrest the reformers. During the period when K'ang worked with the young Emperor, Kuang-hsü had issued almost fifty separate decrees, intended to restructure the Chinese state. From the beginning of this restructuring, educational reform was a significant part of the overall plan.

Prior to the initiation of the Reform Movement, on June 3, 1898, Sun Chia-nai, as the President of the Imperial Board of Civil Office, was instructed to develop a plan for a national university, located in the capital and based on the model of the Foreign Languages Institute. ${ }^{342}$ Eight days later, on June 11, the Kuang-hsü Emperor's first decree called for consultations between the Imperial Grand Council and the Tsungli Yamen to develop a program for the establishment of the Imperial University (Ching-shih ta-hsüeh-t'ang). ${ }^{343}$ On August 9, the Imperial University was officially inaugurated at Peking, with

\footnotetext{
${ }^{340}$ The political maneuvering that led to this breakthrough for K'ang is a fascinating topic, which is beyond the scope of this paper. Luke S. K. Kwong's book, A Mosaic of the Hundred Days, is a very thorough account of the subject. The Grand Councilor and former Imperial Tutor, Weng T'ung-ho, was instrumental in introducing K'ang Yu-wei to the Kuang-hsü Emperor. As previously noted, Weng had been one of the original backers of the Society for the Study of Strength in Peking.

${ }^{341}$ Immanuel Hsü has noted that this was a fabrication started by conservative opponents to the K'ang-Liang faction in the hope that the Empress Dowager would react to close down the Reform Movement. See his The Rise of Modern China, pp. 449-50.

${ }^{342}$ Biggerstaff, The Earliest Modern Government Schools in China, pp. 136-37. Sun Chia-nai had been one of the original elite official members of the Society for the Study of Strength in the summer of 1895 [see page 112]. The Board of Civil Office was the Imperial Board that conferred the rank of chin-shih on those chü-jen who passed the Metropolitan examination in the capital. The Board of Rites was responsible for the administration of the examinations [see previous discussion, Chapter 1, p. 39]. Biggerstaff makes the point that the new institution was to exist separately from the Foreign Languages Institute, although one department, "probably the scientific department", was to be transferred from the language school to the university. That transfer did not occur during the time of the Reform Movement.

${ }^{343}$ The literal translation of this title is "Capital City Hall of Great Learning". The most frequent Western reference is to the Imperial University. In the twentieth century, this institution would be called "Peita" by Chinese students, who had made an acronym of the full name: Pei-ching tahsüeh-t'ang.
} 
W.A.P. Martin as the Dean of Western Studies (hsi-hsüeh tsung-chiao-hsi). ${ }^{344}$ The curriculum of the new university was to cover twelve departments: the sciences of physics, chemistry and the combined department of astronomy and mathematics; the applied scientific technologies of engineering, agriculture, and medicine; law; and the foreign languages, English, French, German, Japanese, and Russian. ${ }^{345}$

Subsequent Imperial edicts dealing with educational reforms were: June 23, replacement of the eight-legged "essay"(pa-ku-wen) in all examinations with essays on "practical" topics, the Five Classics, and the Four Books; July 10, the complete modernization of the Chinese "school" system from the provinces down through the districts, the conversion of all "memorial shrines and temples...not listed in the official records...into schools", and the establishment of "specialized schools for railway engineering, mining, agriculture, tea production and medicine"; July 13, the establishment of a special examination on economics "of practical everyday use"; July 26, the encouragement of a modern press, because "the object of the newspapers being the spread of general knowledge, they should be allowed to comment freely on all current matters, both domestic and foreign, with no restrictions set"; August 6, the encouragement of foreign study, "specifically, students should be selected from various provinces and sent to study in colleges, secondary schools and mining institutions in Japan"; and September 8, the establishment of a medical school at the Imperial University, which was presumably under the directorship of a Dr. Robert Coltman, who was to transfer from the Foreign Languages Institute, where he was professor of surgery and medicine. ${ }^{346}$ This brief examination of

${ }^{344}$ Biggerstaff, The Earliest Modern Government Schools in China, pp. 138; and W.A.P. Martin, The Awakening of China, p. 210. Martin notes that the university began with a "capital of five million taels."

${ }^{345}$ Biggerstaff, The Earliest Modern Government Schools in China, p. 137.

${ }^{346}$ The specific dates of the decrees are taken from Immanuel Hsü's list in his The Rise of Modern China, pp. 446-47. The details of the proclamations comes from the Compilation Group for the "History of Modern China" Series, The Reform Movement of 1898, pp. 93-95. This source also lists an edict on the "encouragement of writing and invention" in which "writers of new books" should be rewarded, if their books contributed to the modernization of the country in a "practical" way. On Dr. Coltman, see Biggerstaff, The Earliest Modern Government Schools in China, p. 138. 
the Imperial decrees indicated how important the subject of education was to the Reform Movement of 1898; and, even though only one innovation (the Imperial University) survived the ending of the Movement in September of 1898, their importance to the topic of educational reforms would come within five years. Under the guidance of Chang Chih-tung, the Ch'ing court not only reinstated every one of these reforms but actually went beyond this initial educational restructuring in the last decade of the dynasty, 1901-1911.

The ideas had come together in 1898; but, the situation at that time seemed to be an ironic parallel to the circumstances of 1895, when Sun Yat-sen had traveled to Tientsin in his unsuccessful attempt to present his educational reform agenda to Li Hung-chang. As noted, Sun's failure may have been due in part to the facts that he chose the wrong man (an aging, preoccupied Li Hungchang) at the wrong time (the beginning of the Sino-Japanese War). In the failure of the 1898 Reform Movement, the wrong man appeared to be K'ang Yuwei, who had managed to create a distance between himself and some of his earlier supporters, such as Chang Chien and Chang Chih-tung. ${ }^{347}$

In addition to the fact that K'ang may have been the wrong man for the leadership, the Reform Movement also suffered from an unfortunate choice in its timing. Other elite officials who had been associated with educational reforms, such as Sun Chia-nai and Liu K'un- ${ }^{348}$, became concerned by the both the pace and the political nature of the reforms, in view of the international crises than

${ }^{347}$ See the previous discussion of the relationship between K'ang's "arrogance" and the resulting estrangement from these earlier supporters [Chapter 2, page 85 and footnote 229]. Liang Ch'i-ch'ao specifically contrasted the two in his Ch'ing-tai hsüeh-shu kai-lun, pp. 102-107. Ayers has noted that Chang Chih-tung "saw merit in and was sympathetic to some specific reform ideas advanced by K'ang... but he also disagreed with elements of the [K'ang-Liang] philosophy and method" in Chang Chih-tung and Educational Reform,p. 139. Weng T'ung-ho, the Imperial Grand Councilor who had been a strong promoter of K'ang was cashiered from all his bureaucratic positions, after political maneuverings by K'ang's supporters in their effort to enhance their leader's position. See Hsü, The Rise of Modern China, pp. 444-45.

${ }^{348}$ Sue Fawn Chung, "The Image of the Empress Dowager Tz'u-hsi," in Cohen and Schrecker, Reform in Nineteenth-Century China, p. 102. Also see the discussion on the lack of support among elite reformers in Bastid, Educational Reformer in Twentieth-Century China, pp. 14-15. 
facing the country. ${ }^{349}$ In his journal entries of the summer of 1898, Li Hungchang caught some of this sense of frustration:

[May]..."Reformers! Reformers! -- idiots and liars, and enemies of their country, I call them! Under the guise of reform, they, led by one who is close to the Emperor, would turn things topsy-turvy in a month, and build a nation over again. K'ang Yuwei is a good man in himself, and he deserves his doctorate of letters -- I admire his writings and his speech very much -- but he does not seem to realize that in advocating wholesale reforms, even though he do so with the best of motives, he is simply affording a different class of 'reformers' -- crazy, hunchbacked barbarians -- opportunity to carry on this propaganda against the foreigners.... [June]..."K'ang proposes to cure all the ills of the nation by one great dose of reform medicine.... He thinks the Board of Mines and Railways will in a week or a month solve problems, and do away with prejudices that have occupied the attention of this country for two thousand years.... But in my very soul I feel that the wild new-doings of the Emperor have given tremendous encouragement to the anti-foreign sentiment; and that once again, but without the strong power for suppression which was mine in the days of 1870 and onward,...l am called upon to do my utmost in the cause of internal order, that the excesses of the country may not bring the outside Governments within our gates again." ${ }^{350}$

If Li's words are read carefully, there is no condemnation of K'ang's reform efforts but rather a condemnation of his undue hastiness and his seeming lack of attention to internal and external political conditions. Li Hung-chang had been fighting the battle for reform for almost a half-century, while he had been

\footnotetext{
${ }^{349}$ An August 30 decree abolished "unnecessary offices", including: the Office of Transmission, which held the power to control access to the Emperor through the memorial process; various Imperial courts; and the governorships of Hupeh, Kwangtung, and Yunnan provinces. See Hsü, The Rise of Modern China, p. 446. The international crises amounted to what has been called the "Scramble for Concessions" and included: the Germans in Shantung; the British in the Yangtze valley; the Russians in Manchuria; the French in the Kwangchow Bay area; and the Japanese in Fukien province. All of these encroachments, demands, and, in some cases, treaty negotiations, took place in the year of 1898. See Mackerras, Modern China, pp. 188-192.

${ }^{350}$ Selections from Mannix, Memoirs of Li Hung Chang, pp. 126-31. Li's description of the antiforeign sentiments of "crazy, hunchbacked, barbarians" probably referred to the members of the Society United in Righteousness and Harmony, who were later known to the West as the Boxers. In May 1898, an Imperial order was issued for local officials to investigate these groups in Shantung, Honan, and Chihli provinces. See Mackerras, Modern China, p. 190. If Li was referring to the Boxers and the possibility of foreign invasion, his words of 1898 were indeed prophetic.
} 
serving the Ch'ing state in the conduct of internal and external affairs. His assessment is at least evidence that some of the opposition to K'ang did not arise from the reform content of his proposals.

In addition to the Imperial University, some other significant educational reforms did remain, at least on paper. ${ }^{351}$ Although the Empress Dowager was forced to accede to the wishes of conservatives with the reinstatement of the "eight-legged" essay in the civil-service examinations, in this edict of November 13,1898 , she maintained that modern schools would continue. Her reason was that modern subjects--such as astronomy, mathematics, geography, and military strategy--were necessary to secure wealth and strength for the country and that their instruction must be combined with the traditional classical education. ${ }^{352}$ Even though Tz'u-hsi's November edict had reinstated the archaic eight-legged essay, her insistence on the continuation of selected modern instruction served notice that there would not be a complete turning back from the progress that had been made in the thirty-five years prior to K'ang Yu-wei's short tenure in official circles. Tz'u-hsi's decision was perhaps the greatest victory that the SelfStrengthening Movement had ever achieved. Here was finally the official recognition and legitimization that Western learning had a place in the Chinese system. Her edict was also the strongest and most official acknowledgment that a fundamental shift had actually occurred in the Chinese intellectual foundation.

Although not actually an integral part of the Reform Movement, Chang Chih-tung's work, Exhortation To Learn (Ch'üan-hsüeh p'ien), could be considered its greatest "legacy" to Chinese educational reform. In the early spring of 1898 , Chang published his collection of essays, and this work became

${ }^{351}$ When the verdict of general failure is assessed for the 1898 Reform Movement, this has been based on the revocation of the more radical educational reforms (regarding the civil-service examinations and the issue of government sponsorship of foreign study for students) and the more radical political reforms (abolition of government positions, public access to the throne, and special appointments). Other, less controversial, provisions remained -- military reorganization, government efficiency adjustments, and measures promoting commercial affairs. See Bays, "Chang Chih-tung After the '100 Days': 1898-1900 As a Transitional Period for Reform Constituencies," in Cohen and Schrecker, Reform in Nineteenth-Century China, p. 317.

${ }^{352}$ Sue Fawn Chung, "The Image of the Empress Dowager," in Cohen and Schrecker, Reform in Nineteenth-Century China, p. 107. 
an instant "best seller" ${ }^{353}$ An indication of the sweeping popularity of the Exhortation To Learn was the fact that after the "revised" edition (published two months later) was presented to the court, the Kuang-hsü Emperor issued an order to the Grand Council for the distribution of copies to forty of the top ranking governors-general, governors and provincial education directors. ${ }^{354}$ At the same time, Chang and Ch'en Pao-ch'en had submitted a joint memorial on reform based on concepts from the Exhortation To Learn, and this memorial became the basis for an imperial decree on changes in the educational system. ${ }^{355}$ Later, on August 22, the court again honored the Exhortation To Learn with an order to the Tsungli Yamen for the publication and distribution of three hundred more copies. ${ }^{356}$

Furthermore, the enthusiasm for the Exhortation To Learn was not confined to the Reform Movement gathered around the young Emperor at court. Scholars and officials who were opposed to the K'ang-Liang faction welcomed the work as an acceptable alternative to the dangers of politicization evident in

\footnotetext{
${ }^{353}$ Ayers notes that there has been some controversy over whether Chang actually authored the entire work. He cites earlier scholars allegations that some of the essays in the Exhortation To Learn were actually written by students in schools within Chang's Hu-kwang jurisdiction. However, Ayers concludes that, although it is impossible to determine whether he used ideas from other sources, the writing style was consistent with Chang's other works. See Ayers, Chang Chih-tung and Educational Reform, p. 150.

${ }^{354}$ The book was presented at court by Huang Shao-chi; see Ayers, Chang Chih-tung and Educational Reform, p. 150. Huang (1854-1908) was a reformer scholar-official from a prominent Chekiang family of officials, who had been connected to the "Pure Flow Party". Huang had been an associate of K'ang Yu-wei from the time of K'ang's first (1888) memorial to the throne. See Rankin, "Local Currents in Reform in Chekiang Before 1900," p. 227; and Schrecker, "The Reform Movement of 1898 and the Ch'ing-i," p. 295. Both essays are from Cohen and Schrecker, Reform in Nineteenth-Century China.
}

${ }^{355}$ Bays, China Enters the Twentieth Century, p. 48. The Imperial decree was probably the July 10, 1898 edict, which ordered a complete modernization of the Chinese school system [see p. 131].

${ }^{356}$ Bays, China Enters the Twentieth Century, p. 48. Ayers notes that the only other Chinese work not associated with the K'ang-Liang faction that was promoted by the court was the Chiaopin-lu k'ang-i by Feng Kuei-fen, in Chang Chih-tung and Educational Reform, p. 150. For the discussion of the Feng's ideas, see Chapter 1,pp. 20-21; for a comparison of the reform ideas of Feng with Chang's early ideas, see the discussion of Chang's 1863 palace examination in Chapter 1 [pp. 36-7]. 
the Kuang-hsü Emperor's reform decrees. ${ }^{357}$ The work gained such popularity that even though it was republished in three different editions by modern lithographic presses in Shanghai, Chinese scholars had to circulate handwritten manuscript copies among themselves. ${ }^{358}$

Chang Chih-tung's thesis has frequently been reduced to the slogan: "Chinese learning for the foundation, Western learning for the utility" ["Chunghsüeh wei t'i, hsi-hsüeh wei yung"]. ${ }^{359}$ However, this idea must really be associated with the Self-Strengthening Movement, rather than with the more advanced synthesis of Chinese and Western learning presented in the Exhortation To Learn. While detractors, such as Liang Ch'i-ch'ao, criticized Chang's proposals as merely a continuation of the earlier policy of borrowing only Western skills $(\mathrm{Hsi}-\mathrm{l})^{360}$, the text of the Exhortation To Learn actually reveals that Chang had a much more comprehensive knowledge of the Western institutions than had previously been presented.

Chang had divided his text into two sections -- the "inner essays" (neip'ien) and the "outer essays" (wai-p'ien)-- in order to present arguments for preservation of the Confucian tradition and for the addition of Western learning to that tradition. The "inner essays" appear to be addressed to the young radical reformers. In "Rectifying political rights" (Cheng ch'üan), Chang wrote:

"Nowadays scholars who become vexed with the present order of things are angry at the foreigners for cheating and oppressing us, at the generals for being

${ }^{357}$ Although the work called for a thorough reform of the traditional Chinese educational system, the fact that Chang did not advocate political reforms made the book more "orthodox" and thus more acceptable to conservative elements. See Bays, "Chang Chih-tung After the "100 Days'," in Cohen and Schrecker, Reform in Nineteenth-Century China, p. 318. The impossibility of separating educational reforms from the political climate of China was noted in the introduction. One of the most radical aspects of the policies of the Reform Movement was the subordination of educational reform to political restructuring. See Bastid, Educational Reform in Early TwentiethCentury China, p. 12.

${ }^{358}$ Ayers, Chang Chih-tung and Educational Reform, p. 150.

${ }^{359}$ For example, see the previous footnote [88] on this phrase in Chapter 1. Liang Ch'i-ch'ao also associated the phrase with Chang Chih-tung, although he did not indicate that it came from the Exhortation To Learn. Liang Ch'i-ch'ao, Ch'ing-tai hsüeh-shu kai-lun, p. 113. See Liang's denunciation of the previous reform efforts on pp. 91-2.

${ }^{360}$ See the previous citation from Liang Ch'i-ch'ao [pp. 91-2]. 
unable to fight, at the ministers for being unable to reform, at the educational authorities for not establishing modern schools, and at the various officials for not seeking to promote industry and commerce. They therefore advocate the theory of people's rights [min-ch'üan] in order to get the people to unite and exert themselves. Alas, where did they find those words that would lead to disorder? The theory of people's rights will bring us not a particle of good but a hundred evils. Are we going to establish a parliament? Among Chinese scholar-officials and among the people there are still many today who are obstinate and uneducated. They understand nothing about the general situation of the world, and they are ignorant of the affairs of state. They have never heard of important developments concerning the schools, political systems, military training, and manufactures of machinery. Suppose the confused and tumultuous people are assembled in one house, with one sensible man there out of a hundred who are witless, babbling aimlessly, and talking as if in a dream -- what use would it be? Moreover, in foreign countries the matter of revenue is mainly handled by the lower house, while other matters of legislation are taken care of by the upper house...."."361

Although Chang was clearly presenting an argument against the institution of a parliamentary system for China, he grounded his discussion in definite knowledge of foreign governmental systems ["the matter of revenue is mainly handled by the lower house, while other matters of legislation are taken care of by the upper house"]. His wording may have sounded conservative, but Chang's argument displayed a much more sophisticated awareness of the relationship between educational reform and political modernization than had been previously been presented in the writing of an elite scholar-official. ${ }^{362}$

In the "outer essays", Chang fashioned an argument that the Chinese educational foundation must be enlarged to include both traditional and Western learning. In addressing the ultraconservative position that China

${ }^{361}$ Excerpt from translation in Gentzler, Changing China, p. 101. "Min-chüan" was advocated by the young radical reformers. Sung Wook Shin has stressed that it was an integral part of the Southern Study Society policy from its founding in 1897 in his "Reform Through Study Societies in the Late Ch'ing Period," in Cohen and Schrecker, Reform in Nineteenth-Century China, pp. 310, 316. Later, Sun Yat-sen also called for "Min-ch'üan", which he defined as "democracy". See Schiffrin, Sun Yat-sen and the Origins of the Chinese Revolution, pp. 212, 321.

${ }^{362}$ For example, review Feng Kuei-fen's essay, "On the Adoption of Western Knowledge," [Chapter 1, pp. 20-21]; Li Hung-chang's letter on the promotion of practical knowledge [Chapter 1, pp. 24-5]; and Hsüeh Fu-cheng's essay, "On Reform," [Chapter 2, pp. 73-6]. 
needed only to strengthen its own tradition in order to persevere, Chang had a harsh assessment:

"Shallow and vulgar expositions, worthless and obsolete eight-legged essays, abstract and contemplative metaphysics, complex and learned studies, frivolous and extravagant poetry are not Confucian learning....Confucianism means broad learning and strict propriety, reviewing the old and knowing the new, being an equal of Heaven and giving full development to the creatures and things of Earth. Confucian government means honoring those to whom honor is due, and loving those to whom love is due, first enriching the people and later instructing them, having civil (administration) but being prepared militarily, and doing the right thing at the right time." ${ }^{363}$

Chang's definition of Confucianism was fairly conventional ["first enriching the people and then instructing them"], but his giving equal importance to civil and military affairs represented a more realistic assessment of current realities ["doing the right thing at the right time"]. His condemnation of the sterility of the current state of Confucian scholarship ["shallow and vulgar expositions, worthless and obsolete eight-legged essays"] was an acknowledgement that some of the radical reformers' criticisms were valid. ${ }^{364}$

In this same essay, "Following the Proper Order" (Hsün-hsü), Chang developed the synthesis of Chinese and Western knowledge that became identified with him. On the "proper order" of instruction, Chang wrote:

"Scholars today must master the classics first, in order to understand the purpose underlying the establishment of education by our ancient Chinese sages and teachers. They must study history, in order to learn the rise and fall of succeeding dynasties of China, and customs of the empire. They must glance over the philosophical works and belles-lettres in order to become thoroughly familiar with Chinese academic ideas and exquisite writings. And then they can select and make use of that Western knowledge which can make up our shortcomings and adopt those Western methods of government which can cure

${ }^{363}$ From Ayers, Chang Chih-tung and Educational Reform, p. 157.

${ }^{364}$ See Liang Ch'i-ch'ao's scathing denunciation of the traditional examination system in his "A General Discussion on Reform" on pp. 121-22. 
our illness...."365

Although Chang had maintained the educational order which characterized the Self-Strengthening Movement, he had increased the range of the Western learning from the previous stress on Western "techniques" $(H s i-l)$ to both Western technology and Western government (Hsi-cheng) in "select and make use of...Western knowledge....and adopt those Western methods of government...."

In another essay, Chang combined both arguments of the Exhortation To Learn in a few comprehensive statements which served notice that the Chinese intellectual tradition would never be able to shift back to its former foundations. Chang's eloquent "exhortation" was :

"Study both the old and the new. The Four Books, Five Classics, Chinese history, government, and geography are old learning. Western government crafts, and history are new learning. The old learning is the fundamental thing; the new learning is for practical use (chiu-hsüeh wei t'i; hsin-hsüeh wei yung). We must not neglect either because of prejudice....Chinese learning is inner learning. Western learning is outer learning. Chinese learning is for regulating the body and the mind. Western learning is for managing the affairs of the world. It is not necessary to seek for everything in the idea of the classics. But it is not necessary to contravene the meaning of the classics. If one's heart is the heart of the sages and one's actions are the actions of the sages, with filial piety, brotherly love, loyalty, and sincerity accepted as virtue, and respect for the ruler and concern for the people accepted as (principles of) government, then no harm will befall the disciples of Confucius even though they use machines and speed over railroads." ${ }^{366}$

Although his words seemed to indicate that he supported a more conservative attitude ["Chiu-hsüeh wei t'i; hsin-hsüeh wei yung"], Chang was actually advocating a much more thorough transformation of Chinese education than the Self-Strengthening reformers had been able to accomplish. The "ad hoc" quality of their successes had actually perpetuated the conservative attitude that modern studies must be kept separate from and could never be equal to

\footnotetext{
${ }^{365}$ From the translation in Teng and Fairbank, China's Response To the West, p. 169. The underlining is mine to emphasize Chang's "proper order" for education.
}

${ }^{366}$ From Ayers, Chang Chih-tung and Educational Reform, p.160. 
Chinese educational tradition. Chang's argument was based on the yin-yang duality of opposites, in that there could not be "inner (Chinese) learning" without "outer (Western) learning" and there could not be "outer (Western) learning" without "inner (Chinese) learning". Both parts were necessary to make the whole of modern education. 


\section{CHAPTER V}

\section{THE LEGACY OF CH'ING EDUCATIONAL REFORMS}

Chang Chih-tung's Exhortation To Learn would have to wait to become the blueprint for Ch'ing educational modernization. After the Empress Dowager had reimposed her "regency" in late 1898, an effective modernization could only have been implemented in an intellectual and political climate of relative stability. However, stability would again be denied to China by the major unresolved issue of the nineteenth century. That issue was the chronic "internal chaos and external troubles" which had plagued the empire from almost the beginning of the century. There would be one final episode of this "internal chaos and external trouble" disease in 1900: the fanatical "Boxer Uprising"; the Eight-Power Allied Expedition to relieve their legations besieged in Peking; the signing of yet another dictated treaty, the Boxer Protocol; and the demand for another ruinous indemnity of $\mathbf{4 5 0}$ million Taels.

Once again, the court had fled and what central government there was existed to react to immediate problems and to negotiate with victorious foreigners. There was no time for rational planning or implementation of programs. In September of 1901, Li Hung-chang negotiated yet another treaty for his sovereign from a position of powerlessness in the face of overwhelming strength. Two months later, this champion of Self-Strengthening died before he could see the full extent of the intellectual revolution which he had helped to bring about.

Chang Chih-tung and Liu K'un-i had already assumed the mantle of educational reform leadership, and they would be the ones to inaugurate the modernization of Chinese education throughout the nation, a need that had been recognized by Chinese elite intellectuals since 1895. Yüan Shih-k'ai had already established himself in Chihli province as a reform governor and a 
promoter of educational modernization. ${ }^{367}$ Of the first transitional generation, only Yüan would be alive to witness the completed politicization of Chinese reform efforts marked by the shift in emphasis from intellectual institutions to political structures, anticipated by the 1898 Reform Movement.

Most of the second transitional generation would witness the beginning of the third Chinese revolution, the cultural changes ushered in by the Ch'en Tu-hsiu's New Culture Movement of 1915. Yen Fu would live to denounce his theories of progress based on Western Social Darwinism after the European First World War. ${ }^{368}$ Chang Chien would become identified with educational reform at the local level, as a member of the new urban intelligentsia, the "gentry and merchants" (shen-shang), a group who truly represented a shift in Chinese intellectual foundations. ${ }^{369}$

The year 1898 was a conclusion to the intellectual revolution just as the year 1861 had been the initiation of that transformation. The failure to politicize the reform effort during the "100 Days" marked a turning point. Even though educational modernization was initiated within five years of K'ang Yu-wei's failure, the trend of the reform effort would become increasingly politicized, and this was the beginning of the next, political, phase of Chinese changes. Of the leaders of the 1898 Reformers included in this discussion, only T'an Ssu-t'ung had died, a martyr to the "100 Days". ${ }^{370}$ K'ang Yu-wei and Liang Ch'i-ch'ao had successfully taken refuge in Japan, as did the revolutionary, Sun Yat-sen. K'ang would remain caught up in his unfinished intellectual transformation; and Liang would move away from him to join the ranks of political reformers. Of course, Sun Yat-sen had completed this transition before the others and his reform

${ }^{367}$ W.A.P. Martin considered that Yüan, Li, and Chang were the three "preeminent" viceroys in the reform of Chinese education. See his The Awakening of China, pp. 212-13.

${ }^{368}$ Grieder, Intellectuals and the State in Modern China, p. 253.

${ }^{369}$ Bastid, Educational Reform in Early Twentieth-Century China, p. 16. Also see the previous discussion on merchants and scholar-officials in traditional China, Chapter 1, pp. 43-4.

${ }^{370}$ In 1898, T'an was reported to have said: "Until now China has not heard of blood being shed in the cause of reform, and therefore the country does not progress. Let it begin with Ssut'ung." From Liang Ch'i-ch'ao's biography of T'an, quoted in Grieder, Intellectuals and the State in Modern China, p. 171. 
effort would remain focused on political change. The failure of 1898 also affected scholar-educators, such as Ts'ai Yüan-pei and Ch'en Tu-hsiu, who would fashion new solutions to China's problems from radical Western sources; and in their efforts to develop a new Chinese system, they would conclude that the tradition could not be the basis for any new system. Both would abandon traditional Confucianism in their search for models; Ts'ai would turn to anarchism and Ch'en to Marxism. Along with the next generation, these two members of the second transitional generation would usher in the third phase of the Chinese revolutions, the cultural transformations.

In a somewhat ironic twist, it was also Japan that Chang Chih-tung selected as the most appropriate country where young Chinese students should be sent for the needed overseas educational experience which he recommended. Many of these "returned students" (liu hsüeh-sheng), such as Ch'iu Chin or Lu Hsün, would return to China with radicalized political ideals, which they would then promote through the modern educational system and the modern literary forms.

However, each of these later changes could trace their beginnings to the intellectual transformation which had occurred in China in the nineteenth century. Before Sun and Liang could argue about Western democratic methods, or Ts'ai could talk of Kropotkin anarchism, or Ch'en could write about a Marxist society, a fundamental shift had had to occur in the Chinese intellectual tradition through the introduction of foreign knowledge. Once that shift had occurred, the intellectual climate became open to many influences which would fundamentally alter Chinese development. This intellectual revolution encompassed both the successful reforms that Joseph Esherick declared had "bred revolutionaries" and the initiation of the "cultural process" within which $\mathrm{Li}$ Ch'ang-chih would place the May Fourth Movement.

This discussion has been an attempt to describe the very real changes which had already taken place in the Chinese intellectual climate by the beginning of the twentieth century, when the Chinese state began to fashion a public, "national", educational structure on the multiple, semi-official and private systems, which had existed for so many centuries. The Imperial commitment to 
substantive reforms would become public with the Imperial Edicts of 1902 through 1904, which were based on Chang Chih-tung's Exhortation To Learn and on the ideas behind the failed efforts of 1898 .

When placed against the larger historical picture, these changes in the "official" attitude toward educational content and structure may seem to be neither timely nor adequate; however, two important factors should be kept in mind. The first is that less than half a century had passed between the establishment of the Foreign Languages Institute in 1862 to the promulgation of the 1902 Imperial edict on the establishment of a public education system in China. During those years the Chinese state had been assaulted from within and without by the recurrent disease of "internal chaos and external troubles", which surely was an historical adjunct to "dynastic death". One of the important themes of this study has been an attempt to show that China's intellectual environment lacked central strength and vigor for most of the nineteenth century. When this fact is kept in mind, the development of an intellectual climate for reform by 1895 appears not only to have been "timely", but perhaps could be considered "revolutionary".

The second factor is that education in China had rested for two millennia on only one very solid foundation, Confucianism, which had served the empire so well that it's inadequacies were not analytically addressed until the second half of the nineteenth century. Although the intellectual vigor had become moribund, the examination system embodied a form of self-perpetuating effectiveness that made the tradition appear to be more vital than it actually was. The very comprehensiveness of the Confucian tradition had become its own enemy, as the philosophical foundations had appeared to be more substantial than they actually were. However, in the thirty years between the initial debate between Wo-jen and Prince Kung on the inclusion of "scientific" studies in elite education at Peking and the diffusion of foreign knowledge throughout the empire with the development of the "study societies" and modern Chinese journalism, the intellectual foundations had not only been acknowledged as insufficient for modern Chinese growth, but they had already begun to be augmented by foreign concepts and nontraditional attitudes. 
Although the Self-Strengthening Movement could be considered to be made up of only "individual" successes and the 1898 Reform Movement might be labeled a general "failure", both of these efforts are indications that the 1902 Imperial edicts were simply an "adequate" official recognition that quite substantial transformations had already occurred and that future changes would be initiated in a broader, coordinated, phase and would be based on a reinvigorated intellectual foundation.

These two factors, separately and together, constitute the true legacy of the late Ch'ing educational reforms. The four decades from the initial SelfStrengthening efforts of Tseng Kuo-fan and Feng Kuei-fen to the publication of the educational reforms of Chang Chih-tung and Liu K'un-i were an era which might be called the "Intellectual Opening" of China. 


\section{SELECTED BIBLIOGRAPHY}

Ayers, William. Chang Chih-tung and Educational Reform In China. Cambridge: Harvard University Press, 1971.

Bastid, Marianne. Educational Reform in Early Twentieth-Century China. Ann Arbor: The University of Michigan Press, 1988. Translator: Paul J. Bailey.

Bays, Daniel H. China Enters the Twentieth Century: Chang Chih-tung and the Issues of a New Age.1895-1909. Ann Arbor: The University of Michigan Press, 1978.

Biggerstaff, Knight. The Earliest Modern Government Schools in China. Ithaca, N.Y.: Cornell University Press, 1961.

Breisach, Ernst. Historiography: Ancient. Medieval \& Modern. Chicago: The University of Chicago Press, 1983.

Cameron, Meribeth E. The Reform Movement in China, 1898-1912. New York:

Octagon Books, Inc., 1963. [Reprint of the 1931 Stanford University Publication]

Chan, Wing-tsit. A Source Book In Chinese Philosophy. Princeton, N.J.: Princeton University Press, 1969.

Chang, Hao. Chinese Intellectuals in Crisis: Search for Order and Meaning (1890-1911). Berkeley: University of California Press, 1987.

Chang, Hao. Liang Ch'i-ch'ao and Intellectual Transition in China, 1890-1907. Cambridge: Harvard University Press, 1971.

Ch'ên, Jerome. China and the West: Society and Culture 1815-1937. Bloomington, Ind.: Indiana University Press, 1979.

Chesneaux, Jean, Marianne Bastid, and Marie-Claire Bérgere. China From the Opium Wars To the 1911 Revolution. New York: Random House, 1976.

Ching, Julia. "Chu Shun-shui, 1600-1682: A Chinese Confucian Scholar in Tokugawa Japan," Monumenta Nipponica, XXX:2, pp. 177-191. 
Chow Tse-tsung. The May Fourth Movement. Cambridge: Harvard University Press, 1960.

Chu, Samuel C. Reformer in Modern China: Chang Chien, 1853-1926. New York: Columbia University Press, 1965.

Cleverly, John. The Schooling of China. Sydney, Australia: George Allen \& Unwin Australia Pty. Ltd., 1985.

Cohen, Paul A. Beyond Tradition and Modernity: Wang T'ao and Reform in Late Ch'ing China. Cambridge: Harvard University Press, 1974.

Cohen, Paul A. 1988. "The Post-Mao Reforms in Historical Perspective," The Journal of Asian Studies, Vol. 47:3, pp. 518-40.

Cohen, Paul A. and John E. Schrecker, eds. Reform in Nineteenth Century China. Cambridge: Harvard University Press, 1976.

Compilation Group for History. The Reform Movement of 1898. Beijing: Foreign Languages Press, 1976.

deBary, Wm. Theodore, Wing-tsit Chan, and Burton Watson, eds. Sources of Chinese Tradition, Volume I. New York: Columbia University Press, 1960.

Dirlik, Arif. The Origins of Chinese Communism. New York: Oxford University Press, 1989.

Eastman, Lloyd E. Family. Field, and Ancestors. New York: Oxford University Press, 1988.

Esherick, Joseph W. Reform and Revolution in China. Berkeley: University of California Press, 1976.

Fairbank, John K. "Synarchy Under Treaties," Chinese Thought and Institutions, pp. 204-231. Chicago: The University of Chicago Press, 1967. Editor: John K. Fairbank.

Fairbank, John K., Edwin O. Reischauer, and Albert M. Craig. East Asia: The Modern Transformation. Boston: Houghton Mifflin Company, 1965. Chart on page 353.

Fay, Peter Ward. The Opium War: 1840-1842. Chapel Hill: The University of North Carolina Press, 1976. 
Feuerwerker, Albert. China's Early Industrialization. New York: Atheneum, 1970.

Feuerwerker, Albert, Rhoads Murphey and Mary C. Wright, eds. Approaches To Modern Chinese History. Berkeley: University of California Press, 1967.

Gasster, Michael. Chinese Intellectuals and the Revolution of 1911. Seattle: University of Washington Press, 1969.

Gentzler, J. Mason, ed. Changing China. New York: Praeger Publishers, 1977.

Gray, Jack, ed. Modern China's Search for a Political Form. London: Oxford University Press, 1969.

Grieder, Jerome B. Intellectuals and the State in Modern China. New York: Macmillan Publishing Co., Inc., 1981.

Hayhoe, Ruth and Marianne Bastid, eds. China's Education and the Industrialized World. Armonk, N.Y.: M.E. Sharpe, Inc., 1987.

Ho Ping-ti. The Ladder of Success in Imperial China: Aspects of Social Mobility, 1368-1911. New York: Columbia University Press, 1962.

Hsü, Immanuel C. Y. The Rise of Modern China. New York: Oxford University Press, 1973.

Hsüeh Chün-tu. "Sun Yat-sen, Yang Chü-yün, and the Early Revolutionary Movement in China," Revolutionary Leaders of Modern China, pp. 102122. New York: Oxford University Press, 1971. Editor: Chün-tu Hsüeh.

Huang, Philip C. Liang Ch'i-ch'ao and Modern Chinese Liberalism. Seattle: University of Washington Press, 1972.

Hughes, E. R. The Invasion of China By the Western World. London: Adam and Charles Black, 1937.

Hummel, Arthur W., ed. Eminent Chinese of the Ch'ing Period (1644-1912), 2 Volumes. Washington, D.C.: U.S. Government Printing Office, 1943-1944.

Iriye, Akira, ed. The Chinese and the Japanese. Princeton, N.J.: Princeton University Press, 1980.

Johnson, David, Andrew J. Nathan, Evelyn S. Rawski, eds. Popular Culture in Late Imperial China. Berkeley: University of California Press 1985. 
Kwong, Luke S. K. A Mosaic of the Hundred Days: Personalities, Politics, and Ideas of 1898. Cambridge: Harvard University Press, 1984.

Legge, James. The Chinese Classics, Volume III, "The Shoo King". Hong Kong: Hong Kong University Press, 1960. Original Chinese text, translation, and notes.

Legge, James. Confucius: Confucian Analects. The Great Learning \& The Doctrine of the Mean. NewYork: Dover Publications, Inc., 1971.

Legge, James. The Works of Mencius. New York: Dover Publications, Inc., 1970.

Levenson, Joseph R. Confucian China and Its Modern Fate: A Trilogy.

Berkeley: University of California Press, 1972.

Li, Dun J., ed. The Essence of Chinese Civilization. Princeton, N.J.: D. Van Nostrand Company, Inc., 1967.

Liang Ch'i-ch'ao. Ch'ing-tai hsüeh-shu kai-lun. (Intellectual Trends in the Ch'ing Period.) Cambridge: Harvard University Press, 1959. Translated by Immanuel C.Y. Hsu.

Mackerras, Colin. Modern China. San Francisco: W. H. Freeman and Company, 1982.

Mackinnon, Stephen R. Power and Politics in Late Imperial China: Yuan Shih$K^{\prime}$ ai in Beijing and Tianjin,1901-1908. Berkeley: University of California Press, 1980.

Mannix, William Francis. Memoirs of Li Hung Chang. Boston: Houghton Mifflin Company, 1923.

Martin, W. A. P. The Awakening of China. New York: Doubleday, Page \& Company, 1910.

Miller, J. Martin. China. Ancient and Modern: The Yellow Peril. New York: No Publisher listed, 1900.

Ping Wen Kuo. The Chinese System of Public Education. New York: Teachers College, Columbia University Press, 1914.

Rankin, Mary Backus. Early Chinese Revolutionaries. Cambridge: Harvard University Press, 1974. 
Rawski, Evelyn Sakakida. Education and Popular Literacy in Ch'ing China. Ann Arbor: The University of Michigan Press, 1979.

Reinsch, Paul S. Intellectual and Political Currents in the Far East. Freeport, N.Y.: Books for Libraries Press, 1971 reprint of 1911 publication.

Scalapino, Robert A. and George T. Yu. Modern China and Its Revolutionary Process. Berkeley: University of California Press, 1985.

Schiffrin, Harold Z. Sun Yat-sen and the Origins of the Chinese Revolution. Berkeley: University of California Press, 1970.

Snow, Edgar. Red Star Over China. Toronto: Bantam Books, Grove Press, Inc., 1984.

Snow, Helen Foster. The Chinese Communists. Westport, Conn.: Greenwood Publishing Company, 1977.

Spence, Jonathan. To Change China. Boston: Little, Brown and Company, 1969.

Teng, Ssu-yu and John K. Fairbank. China's Response To the West. A Documentary Survey, 1839-1923. New York: Atheneum, 1963.

Wakeman, Frederic E., Jr. 1986. "China and the Seventeenth-Century Crisis," Late Imperial China, Vol. 7, No, 1, pp. 1-26.

Wakeman, Frederic E., Jr. The Fall of Imperial China. New York: Macmillan Publishing Co., Inc., 1975.

Wang, James C. F. Contemporary Chinese Politics: An Introduction. Englewood Cliffs, N.J.: Prentice Hall,1989. Third Edition.

Wang, Y. C. Chinese Intellectuals and the West, 1872-1949. Chapel Hill: The University of North Carolina Press, 1966.

Wilbur, C. Martin. Sun Yat-sen. Frustrated Patriot. New York: Columbia University Press, 1976.

Wills, John E., Jr. "Maritime China from Wang Chih to Shih Lang: Themes in Peripheral History," in From Ming To China, pp. 203-238. New Haven, Conn.: Yale University Press, 1979. Editors: Jonathan D. Spence and John E. Wills, Jr. 
Wright, Mary C., ed. China In Revolution: The First Phase, 1900-1913. New Haven, Conn.: Yale University Press, 1968.

Wright, Mary C. The Last Stand of Chinese Conservatism: The T'ung-Chin Restoration,1862-1874. New York: Atheneum, 1967, Second Printing. 